\title{
Airborne Gamma-Ray Spectrometer and \\ Magnetometer Survey
}

Iditarod Quadrangle

(Alaska)

\section{Final Report Volume I}

Prepared For The Department Of Energy

Grand Junction Office

Grand Junction, Colorado 81501

Under

Bendix Field Engineering Corporation

Grand Junction Operations, Grand Junction, Colorado

Subcontract No. 79-321-L

Project No. 40-79-4179

March 1980

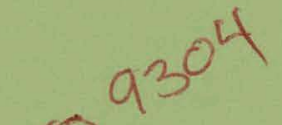

by

Aero Service Division

Western Geophysical Company of America

Houston, Texas 77001

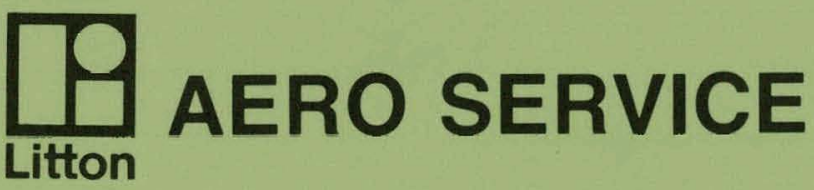




\section{DISCLAIMER}

This report was prepared as an account of work sponsored by an agency of the United States Government. Neither the United States Government nor any agency Thereof, nor any of their employees, makes any warranty, express or implied, or assumes any legal liability or responsibility for the accuracy, completeness, or usefulness of any information, apparatus, product, or process disclosed, or represents that its use would not infringe privately owned rights. Reference herein to any specific commercial product, process, or service by trade name, trademark, manufacturer, or otherwise does not necessarily constitute or imply its endorsement, recommendation, or favoring by the United States Government or any agency thereof. The views and opinions of authors expressed herein do not necessarily state or reflect those of the United States Government or any agency thereof. 


\section{DISCLAIMER}

Portions of this document may be illegible in electronic image products. Images are produced from the best available original document. 
This report was prepared as an account of work sponsored by the United States Government. Neither the United States nor the United States Department of Energy, nor any of their employees, nor any of the contractors, subcontractors, or their employees, makes any warranty, express or implied, or assumes any legal liability or responsibility for the accuracy, completeness, or usefulness of any information, apparatus product or process disclosed, or represents that its use would not infringe privately owned rights. 
AIRBORNE GAMMA-RAY SPECTROMETER

AND

MAGNETOMETER SURVEY

IDITAROD QUADRANGLE

(Alaska)

FINAL REPORT

VOLUME I

Prepared for The Department of Energy Grand Junction Office

Grand Junction, Colorado 81501

Under

Bendix Field Engineering Corporation Grand Junction Operations,

Subcontract No. 79-321-L

Project No. 40-79-4179

March, 1980

\section{by}

AERO SERVICE DIVISION WESTERN GEOPHYSICAL COMPANY

OF AMERICA

HOUSTON, TEXAS

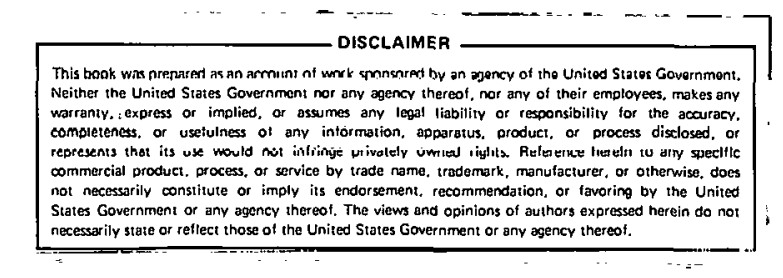

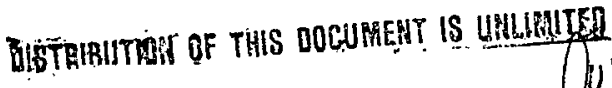




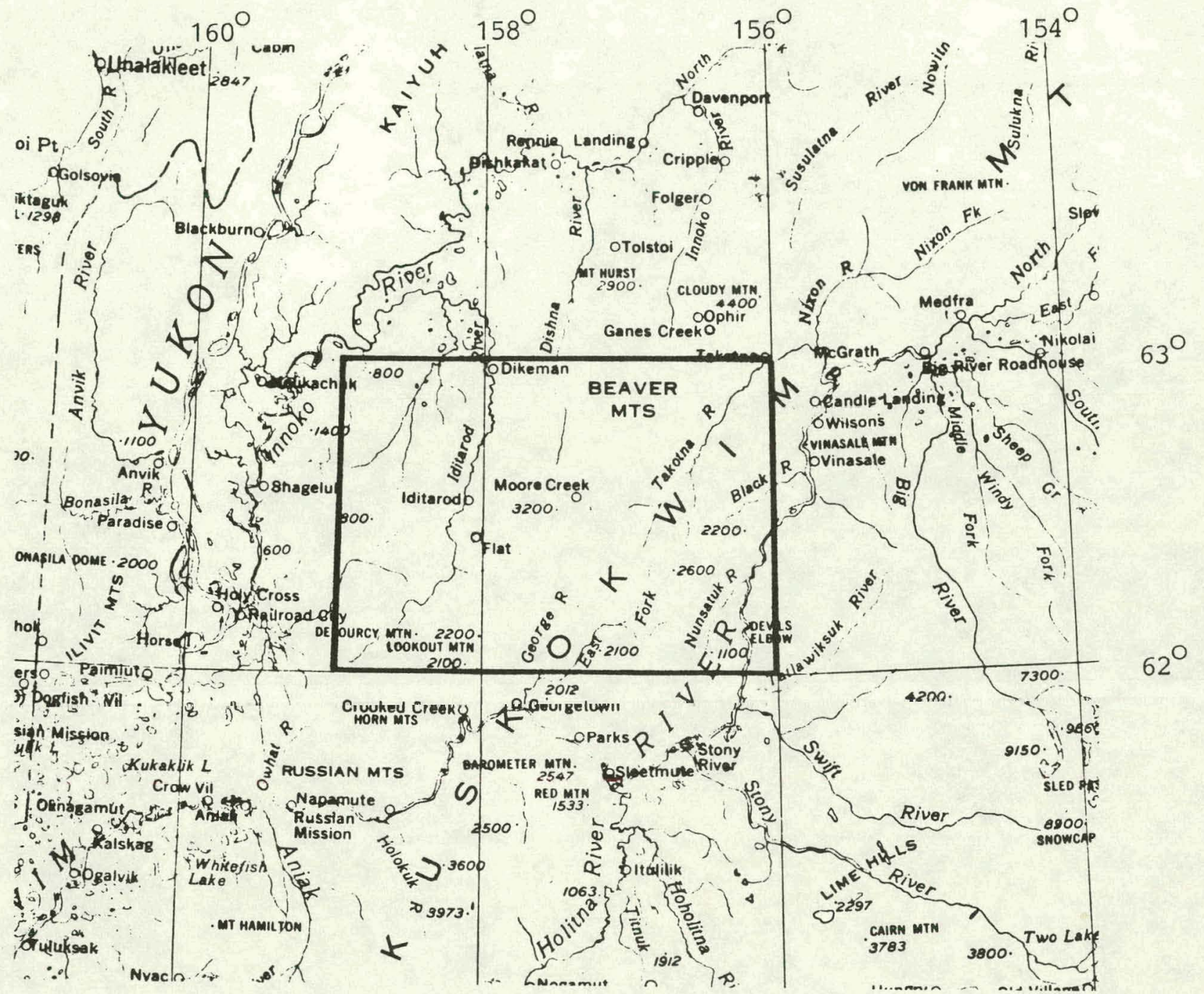

FIGURE 1

IDITAROD

INDEX MAP 
$\underline{T} \underline{A} \underline{B} \underline{L} \underline{E} \quad \underline{O} \underline{E} \quad \underline{C} \underline{O} \underline{N} \underline{T} \underline{\underline{E}} \underline{N} \underline{\mathrm{T}} \underline{\mathrm{S}}$

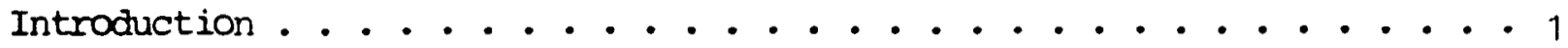

Data Acquisition . . . . . . . . . . . . . . . . . 3 Aircraft ....... . . . . . . . . . . . . . . . 3 Gamma-Ray Spectrometer System . . . . . . . . . . . . . . 4 Magnetometer ..................... . 6

Production summary ................. 7

Data Reduction ......................... 14

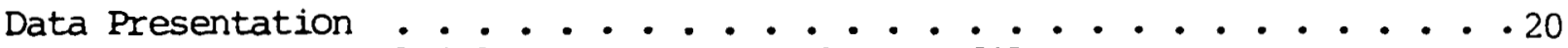
Radiometric Multiple-Parameter Stacked Profiles . . . . . . 20 Magnetic and Ancillary Parameter Stacked Profiles . . . . . . . 21

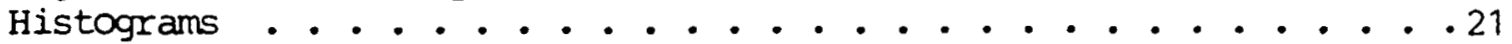
Anomaly Maps ................... . . . . . . . . .

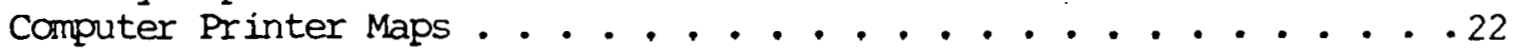

Geology . . . . . . . . . . . . . . . . . . . . 23 Introduction . . . . . . . . . . . . . . . . . 23 Stratigraphy . . . . . . . . . . . . . . . . . . . 24 Structure ....... . . . . . . . . . . . . . . 26 Economic Geology .. . . . . . . . . . . . . . . . 27

Interpretation . . . . . . . . . . . . . . . 28

General . . . . . . . . . . . . . . . . . . 28

Geochemical Analysis ... . . . . . . . . . . . 29

Anomaly Map Analysis . . . . . . . . . . . . . . 32

Selected References . . . . . . . . . . . . . . . 50 


\section{$\underline{L} \underline{I} \underline{S} \underline{T} \quad \underline{O} \underline{F} \quad \underline{T} \underline{A} \underline{B} \underline{L} \underline{E} \underline{S}$}

Table I

Aircraft Specifications and Characteristics . . . . 3

Table II

Daily Production Summary . . . . . . . . . . 9

Table III

Legend to Total Field Map . . . . . . . . . 33

Table IV

Legend to Potassium Average Map . . . . . . . . 35

Table V

Legend to Uranium Average Map . . . . . . . . • 37

Table VI

Legend to Thorium Average Map . . . . . . . . . 39

Table VII

Legend to Uranium/Potassium Ratio Map . . . . . . . 41

Table VIII

Legend to Uranium/Thorium Ratio Map . . . . . . . 43

Table IX

Legend to Thorium/Potassium Ratio Map . . . . . . 44 45 


$$
\underline{I} \underline{I} \underline{S} \underline{T} \quad \underline{O} \underline{F} \quad \underline{F} \underline{I} \underline{G} \underline{U} \underline{R} \underline{E} \underline{S}
$$

Figure 1

Index Map

Figure 2

Final Flight Path Map . . . . . . . . . . 2

Figure 3

Block Diagram HISENS AGRS 3000F System . . . . . . 5

Figure 4

Terrain Clearance Histogram . . . . . . . . 12

Figure 5

Ground Speed Histogram . . . . . . . . . 13

Figure 6

Data Reduction Flow Diagram . . . . . . . . 15

Figure 7

Total Magnetic Field Contour Map . . . . . . . 34

Figure 8

Potassium Average Contour Map . . . . . . . . 36

Figure 9

Uranium Average Contour Map . . . . . . . . 38

Figure 10

Thorium Average Contour Map . . . . . . . . . 40

Figure 11

Uranium/Potassium Ratio Map . . . . . . . . . 42

Figure 12

Uranium/Thorium Ratio Map . . . . . . . . . . 44

Figure 13

Thorium/ Potassium Ratio Map . . . . . . . . . 46

Figure 14

Interpretation Map . . . . . . . . . . 48 


\section{$\underline{T} \underline{A} \underline{B} \underline{L} \underline{E} \underline{O} \underline{F} \underline{A} \underline{P} \underline{P} \underline{E} \underline{N} \underline{D} \underline{I} \underline{C} \underline{E} \underline{S}$}

Appendix A

Geologic Legend . . . . . . . . . . . . . . Al

Appendix B

List of Geologic Units by Anomaly . . . . . . . . . . Bl

Appendix C

List of Anomalies by Geologic Unit . . . . . . . . . Cl

Appendix D

Mean Radiometric Values by Geologic Unit . . . . . . . Dl

Appendix E

Standard Deviation Table ............. El

Appendix $\mathrm{F}$

Format, Single Record Data Listing . . . . . . . . Fl

Appendix G

Format, Average Record Data Listing . . . . . . . . G Gl

Appendix $\mathrm{H}$

Format, DOE STNGLE RECORD REDUCED DATA TAPE . . • • • • $\mathrm{HI}$

Appendix I

Format, DOE RAW SPECTRAL DATA TAPE . . . . . . . . . Il

Appendix $\mathrm{K}$

Format, DOE STATISTICAL ANALYSIS DATA TAPE . . . . . . Kl

Appendix L

Format, DOE STATİ̈TICAL ANALYSIS SUMMARY DATA TAPE . . . L Ll

Appendix $M$

Format, DOE MAGNETIC DATA TAPE ............ MI

Appendix N

Reduced Calibration and Test Line Data . . . . . . N1 
INTRODUCTION

During the months of July, August and September of 1979, Aero Service Division Western Geophysical Company of America conducted an airborne high sensitivity gamma-ray spectrometer and magnetometer survey over (10) ten $3^{\circ} \mathrm{x}$ $1^{\circ}$ NTMS quadrangles of West-Central Alaska. This report discusses the results obtained over the Iditarod map area.

Traverse and tie-line directions were east-west and north-south respectively. Traverse spacing was approximately 6.25 miles, while tie-lines were flown approximately 25 miles apart. A total of 13,960.5 line miles of geophysical data were acquired, compiled and interpreted during the survey, of which 1424.8 line miles are in this quadrangle.

The study was carried out on behalf of the Department of Energy under Bendix Field Engineering Corporation, Subcontract No. 79-321-L, Project No. 40-79-4179, as part of the Aerial Radiometric and Magnetic Reconnaissance Survey Program, designed to map the regional distribution of the natural radioelements for the principal rock units of the United States in support of the National Uranium Resource Evaluation (NURE) program.

The data were reduced and compiled in accordance with the technical specifications of the contract as stated in BFEC 1200-C and BFEC 1250-A. The parameters used in the processing of the radiometric data have been substantiated in a previously submitted calibration report of the Sikorsky installed airborne gamma-ray spectrometer system. 

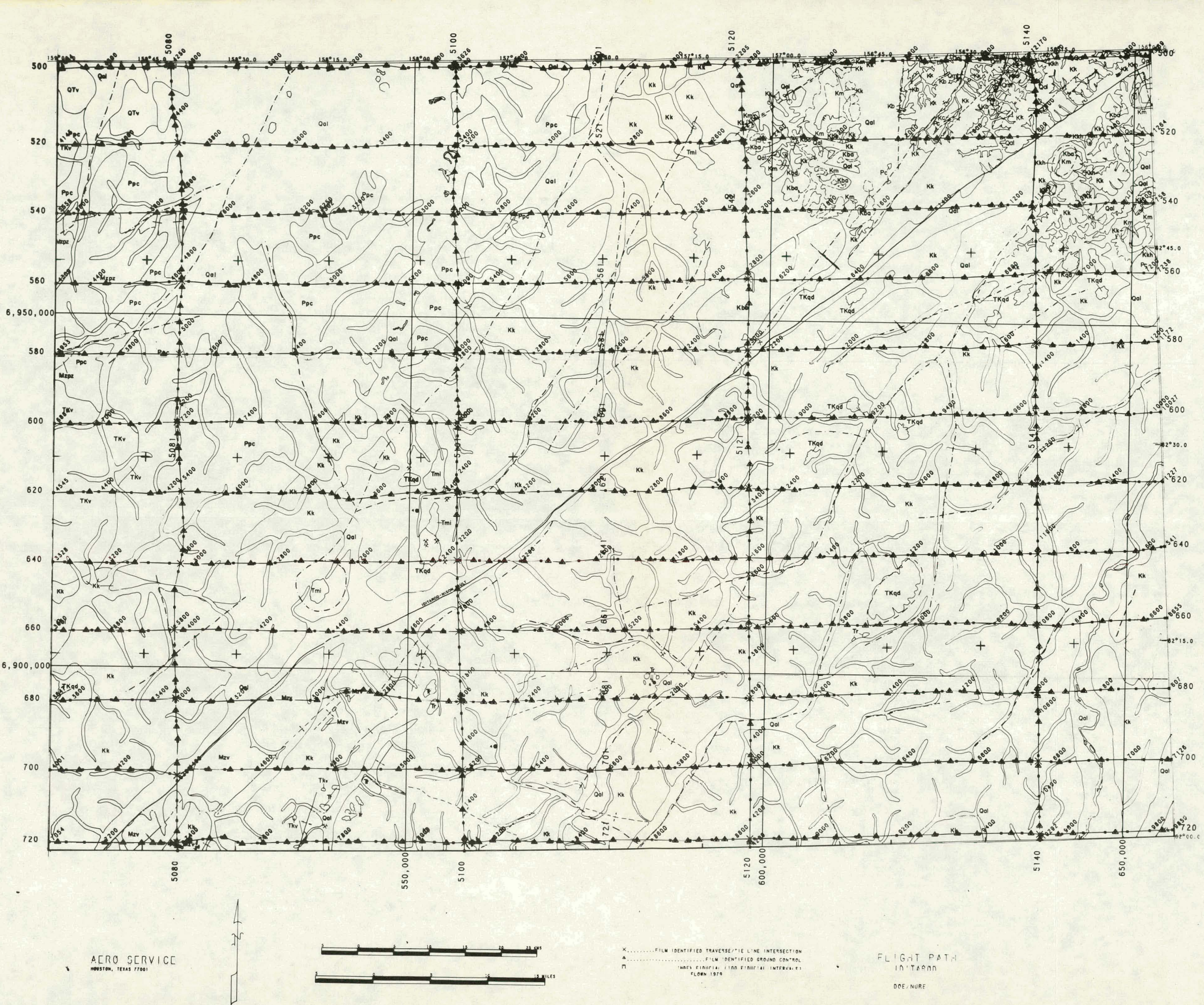


\section{DATA ACQUISITION}

Aircraft

The survey was carried out using a Sikorsky S-58T helicopter, registration N 95423, owned and operated by Carson Helicopters, Inc., Perkasie, Pennsylvania. The flight crew included a pilot (Carson), a navigator (Carson) and an electronic operator (Aero Service). Some of the more pertinent characteristics and specifications of the aircraft are listed below:

T A B L E I

\begin{tabular}{|c|c|c|}
\hline Aircraft & - & Sikorsky Model S-58T, Registration N 95423 \\
\hline Engine & - & Pratt - Whitney PT 6T Twinpack \\
\hline Take off power & - & 1875 Shaft HP. \\
\hline Fuel Capacity & - & 350 U. S. Gal. \\
\hline Hourly Fuel Consumption & - & 100 U. S. Gal. \\
\hline Range Cruise Speed & - & 300 Miles \\
\hline Rate of Climb & - & 1200 Feet per Min. \\
\hline Service Ceiling & - & 12500 Feet \\
\hline Maximum Gross Weight & - & 13000 Lbs. \\
\hline Empty Weight & - & 7200 Lbs. \\
\hline Useful Load & - & 5800 Lbs. \\
\hline Pay Load & - & 1700 Lbs. \\
\hline
\end{tabular}




\section{Gamma-Ray Spectrometer System}

The survey was conducted using Aero Service's HISENS Airborne Gamma-ray Spectrometer 3000-F System, shown in block diagrammatic form in Figure 3, page 5. The primary detector package consists of 13 logs of 4" $x 4^{\prime \prime} \times 15^{\prime \prime}$ of Polyscin ${ }^{(R)}$, NaI(Tl), each log hermetically sealed in a stainless steel container and coupled to a high quality photo-multiplier tube. The logs are assembled in three slabs of respectively 4, 4 and 5 logs each. Each slab is enclosed in a heated and thermally stabilized container. Total volume of the

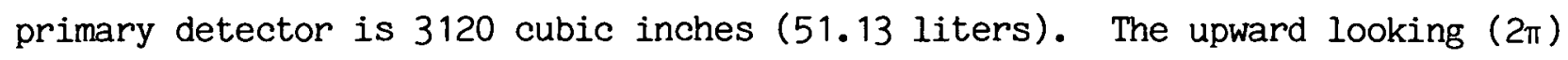
detector consists of two 4" $x$ 4" $x$ 16" logs of Polyscin ${ }^{(R)}, \operatorname{NaI}(T I)$, also hermetically sealed in a steel container and coupled to high quality photomultiplier tubes. The two logs are enclosed as a slab in the same container that houses the slab of 5 logs of Polyscin. The upward looking crystals are mounted on top of the $4 \pi$ sensor, separated by a $0.75 "$ slab of lead shielding, in order to obtain the prescribed shielding effect of $85 \% @ 3000 \mathrm{KeV}$.

The preamplifiers, which with the photo-multipliers provide virtually the total s1gnal amplification, are also enclosed in the thermally stabilized packages, to ensure maximum signal stability. The output of the preamplifiers is fed into the amplifiers, whose main function is to shape the incoming pulses into a bipolar gausșiạn form.

The mixer-router, the $50 \mathrm{MHz}$ Wilkinson ramp analog to digital onnverter and the multi-channei analyzer of both the primary and $2 \pi$ spectrometer systems are commercially available units, supplied by Canberra Industries. The data from the two spectrometers are output to the data controller, former by a Hewlett Packard 21 MX minicomputer system, which stores the data, formats them, outputs them on tape and compares the tape recorded data with the data stored in memory. Additional data recorded on tape are radar altitude, baro- 


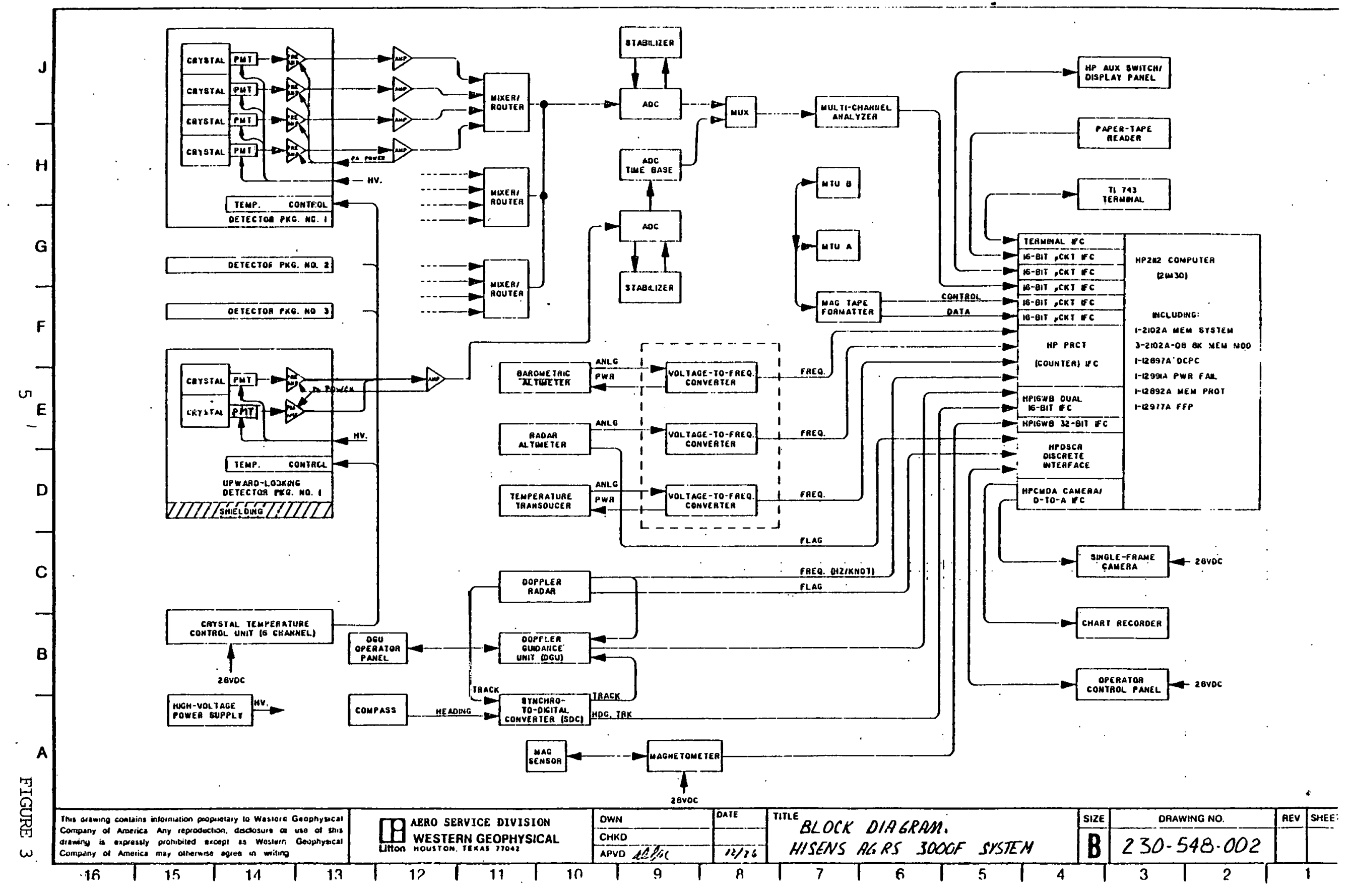


metric pressure, atmospheric temperature, magnetometer data, real time, gammaray spectrometer system live-time and other ancillary data such as additional navigational data. Two tape drives were employed and automatic switching between the two occurs as each tape ends. Additional ancillary equipment includes a cathode ray tube display, a Clevite Brush 6-channel analog recorder and a $35 \mathrm{~mm}$ frame camera, triggered by the data controller at a preset interval.

\section{Magnetometer}

The magnetic sensor used for the survey was a Geometrics G-803 proton free-precession magnetometer, housed in a fiberglass bird and towed 75 feet below the aircraft in order to assure reliable data with minimal aircraft compensation. 
PRODUCTION SUMMARY

The $3^{\circ} \times 1^{\circ}$ NTMS quadrangle of Iditarod, Alaska, was surveyed as part of a subcontract covering the nine quadrangles of Norton Bay, Nulato, Ruby, Unalakleet, Ophir, Medfra, Iditarod, McGrath and Sleetmute. An extension to the same subcontract covered the reconnaissance survey of the $3^{\circ} \times 1^{\circ}$ NTMS quadrangle of Kantishna River and the detailed survey of the Four Corners area, located at the four corners of the Ruby, Kantishna River, Medfra and Mt. McKinley quadrangles. The main subcontract covered the flying of a total of 11,925.7 line miles of geophysical data, of which 1424.8 miles are in the Iditarod quadrangle. The extension subcontract covered the flying of 1346.8 line miles of reconnaissance surveying and 688 line miles of detailed survey.

The main bases of operation were, for the original subcontract, Galena, Alaska, in the Nulato quadrangle, for the northern portion of the survey, and McGrath, Alaska, in the McGrath quadrangle, for the southern portion of the survey. For the additional subcontract Manley, Alaska, in the Kantishna River Quadrangle was used as the main base of operations.

Throughout the survey extensive use was made of the many small landing strips distributed within the area. A small, twin engine fixed wing aircraft was used to ferry fuel supplies to these landing strips. These fuel caches were then subsequently used to allow refuelling stops by the helicopter.

The first production flight was made on July 12, 1979. The final production flight of the original subcontract was flown on September 12, 1979. Maps covering the survey areas of the additional subcontract were received in McGrath on September 18, 19\%9, on which day the helicopter was ferried to Manley, Alaska. The last production flight of the additional subcontract was flown on September 27, 1979. 
Between July 12 and September 12, the end of the flying of the original subcontract, a total 67 sorties were made on 27 production days. Total flying time of the helicopter amounted to 191.6 hours. Fourteen days were lost due to aircraft repair and maintenance, mainly because of an engine failure in the beginning of the survey and a fracture of the tail rotor near the end of the survey. Inclement weather prevented production on 21 days and one (1) day of production was lost due to inadequate fuel supplies in McGrath.

For the original contract average production per hour actual flying time was 62.2 miles. An average of 441.7 line miles of data was acquired each actual production day. When counted over the entire 78 days duration of the survey, average production was 152.9 line miles per day.

The flying of the extension survey mileage was accomplished on September 27, 1979. The extension survey took a total of ten (10) production flights on four (4) days. A total of 1346.8 line miles of reconnaissance data and 688 line miles of detailed survey data were gathered in 33.4 hours of flying. Inclement weather prevented production flying during five (5) days. Average production for the extension subcontract was 60.92 line miles per huur actual flying time. Progress averaged 508.7 line miles of data per production day and 226.1 line miles over the duration of the extension survey.

Time lost due to electronic equipment repair or maintenance during both the original survey and its extension was negligeable. A complete summary of daily production for hoth the original survey and its extension is given in Table II, päge 9.

The projected spacing for the Iditarod quadrangle was 6.25 miles for traverse lines and 25 miles for tie lines. The specified terrain clearance for the survey was 400 feet. Figure 4 shows a histogram of the terrain clearance of the aircraft as recorded by the radar altimeter. The histogram 
T A B L E II

DAILY PRODUCTION SUMMARY

Iditarod Quadrangle

$\frac{\text { DATE }}{\text { 07/12/79 Galena, Alaska }}$ 07/13/79 Galena, Alaska 07/14/79 Galena, Alaska 07/15/79 Galena, Alaska 07/16/79 Galena, Alaska 07/17/79 Galena, Alaska 07/18/79 Galena, Alaska 07/19/79 Galena, Alaska 07/20/79 Galena, Alaska 07/21/79 Galena, Alaska 07/22/79 Galena, Alaska 07/23/79 Galena, Alaska 07/24/79 Galena, Alaska 07/25/79 Galena, Alaska 07/26/79 Galena, Alaska 07/27/79 Galena, Alaska 07/28/79 Galena, Alaska 07/29/79 Galena, Alaska 07/30/79 Galena, Alaska 07/31/79 Galena, Alaska

08/01/79 Galena, Alaska 08/02/79 Galena, Alaska 08/03/79 Galena, Alaska 08/04/79 Galena, Alaska 08/08/79 Galena, Alaska 08/08/79 Galena, Alaska 08/08/79 McGrath, Alaska 08/09/79 McGrath, Alaska 08/10/79 McGrath, Alaska 08/11/79 McGrath, Alaska 08/12/79 McGrath, Alaska 08/13/79 McGrath, Alaska 08/14/79 McGrath, Alaska 08/15/79 McGrath, Alaska 08/16/79 McGrath, Alaska 08/17/79 McGrath, Alaska 08/18/79 McGrath, Alaska 08/19/79 McGrath, Alaska 08/20/79 McGrath, Alaska
ACTIVITY

Production

Production

Aircraft engine repair Aircraft engine repair Aircraft engine repair Aircraft engine repair Aircraft engine repair Aircraft engine repair Aircraft engine repair Engine test

Production

Rain

Rain

Production

Production

Production

Production

Rain

Production

Rain

Rain

Production

Production

Rain

Rain

Rain, ferry to McGrath

Rain

High wind, turbulence

Production

Production

Production

Production

Rain

Production

Rain

Rain

Production

Rain

Rain
FLIGHT NO.

$2,3,4$

5,6

8,9

10,11

$12,14,15$

16,17

18

19

20

$21,22,23,24,25$
27,28

29,30

31,32

$33,34,35$

36,37

38 
Daily Production Summary Iditarod Quadrangle cont'd.

\section{DATE $\quad$ BASE (S)}

$08 / 21 / 79$

$08 / 22 / 79$

$08 / 23 / 79$

$08 / 24 / 79$

$08 / 25 / 79$

$08 / 26 / 79$

$08 / 27 / 79$

$08 / 28 / 79$

$08 / 29 / 79$

$08 / 30 / 79$

$08 / 31 / 79$

09/01/79

$09 / 02 / 79$

$09 / 03 / 79$

$09 / 04 / 79$

$09 / 05 / 79$

$09 / 06 / 79$

$09 / 07 / 79$

$09 / 08 / 79$

$09 / 09 / 79$

$09 / 10 / 79$

$09 / 11 / 79$

$09 / 12 / 79$

$09 / 13 / 79$

$09 / 14 / 79$

$09 / 15 / 79$

$09 / 16 / 79$

$09 / 17 / 79$

$09 / 18 / 79$

$09 / 19 / 79$

$09 / 20 / 79$

$09 / 21 / 79$

$09 / 22 / 79$

$09 / 23 / 79$

$09 / 24 / 79$

$09 / 25 / 79$

$09 / 26 / 79$

$09 / 27 / 79$
McGrath, Alaska

McGrath, Alaska

McGrath, Alaska

McGrath, Alaska

McGrath, Alaska

McGrath, Alaska

McGrath, Alaska

McGrath, Alaska

McGrath, Alaska

McGrath, Alaska

MuGrath, Alaska

McGrath, Alaska

McGrath, Alaska

McGrath, Alaska

McGrath, Alaska

McGrath, Alaska

McGrath, Alaska

McGrath, Alaska

McGrath, Alaska

McGrath, Alaska

McGrath, Alaska

McGrath, Alaska

MoGrath, Alaska

McGrath, Alaska

McGrath, Alaska

McGrath, Alaska

McGrath, Alaska

McGrath, Alaska

McGrath, Alaska

Manley, Alaska

Manley, Alaska

Manley, Alaska

Manley, Alaska

Manley, Alaska

Manley, Alaska

Manley, Alaska

Manley, Alaska

Manley, Alaska
ACTIVITY

Production

Production

Production

Production

Production

Rain

Rain

RaIn

Rain

Rain

Production

Tail rotor U/S

Tail rotor U/S

Tail rotor U/S

Tail rotor U/S

Tail rotor U/S

Test flight

Production

Production

Production

Logistics, awaiting

fuel supply

Production

Last production

Original sontract

Awaiting instructions

Awaiting instructions, rain

Awaiting instructions, rain

Crew moved to Manley

Awaiting maps

Ferry to Manley

Rain

Fog, rain

Fog, rain

Produetion

Production

Fog, rain

Fog, rain

Production

$76,77,78$

$79,80,81$
60,61

$62,63,64,65$

66,67

$68,69,70,71$

72,73
$40,41,42$

$43,44,45,46$

52,53

$54,55,56$

$57,58,59$

Production, end of project 85,86 
takes into account all final samples in the Iditarod quadrangle. The mean terrain clearance, as observed, is approximately 420 feet. The ground speed of the aircraft, as determined from the distances between consecutive samples, based on their final X-Y positions, is depicted in graphic form in the histogram of Figure 5, page 13. 


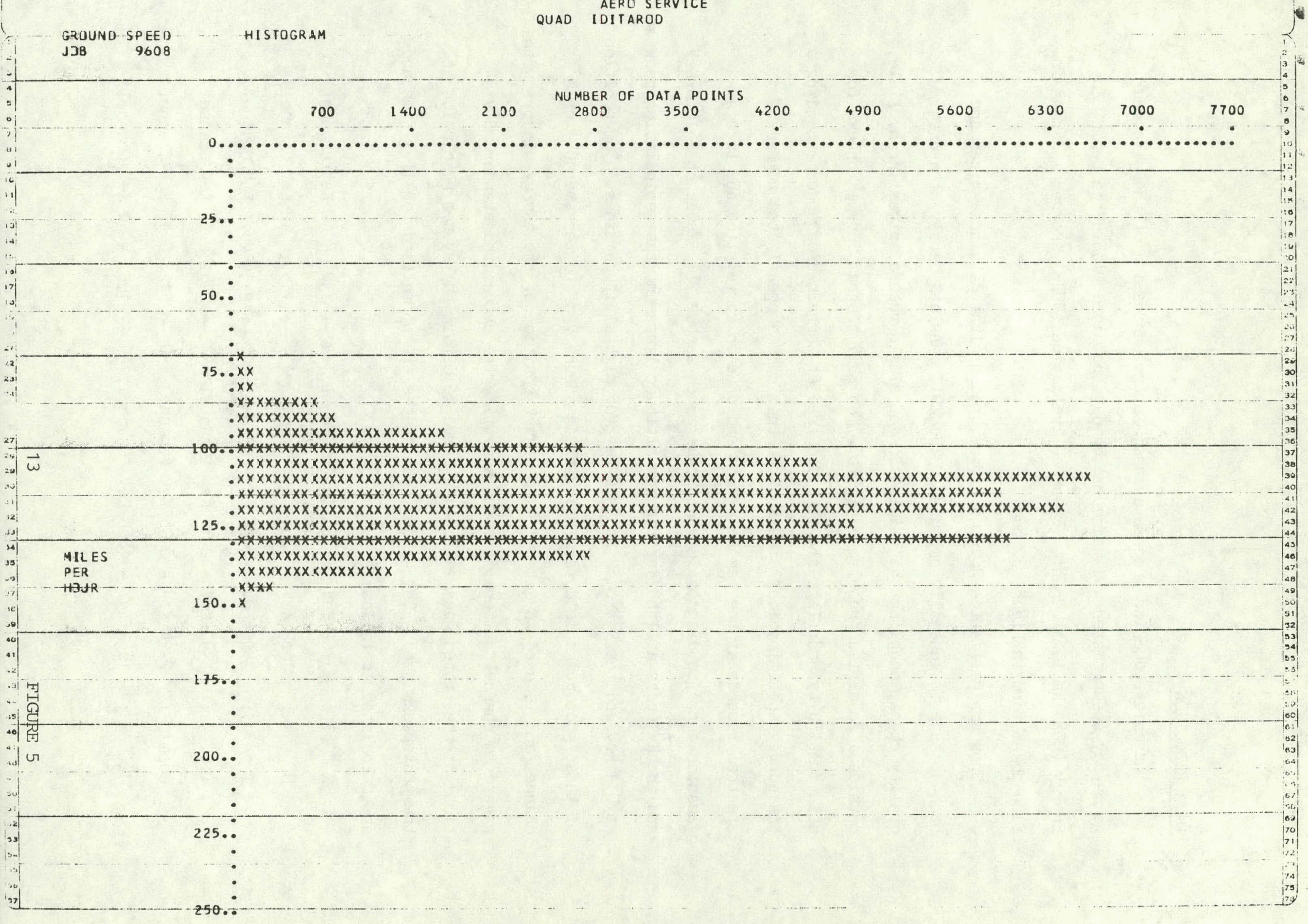


DATA REDUCTION

The data reduction process as used in the processing of the airborne gamma-ray spectrometer and magnetometer data obtained within the Department of Energy (DOE) National Uranium Resource Evaluation (NURE) program is shown in flow chart form in Figure 6, page 15.

Upon arrival in the Houston Office, the digital data are edited and a back-up tape is generally produced. The EDIT consists partly of a data quality check, enabling the elimination of single record spikes in any field, outside a specified preselected limit. The EDIT program further checks for data continuity and flags all data acquired at terrain clearances exceeding the survey specification. The EDIT further sums a preselected number of spectral records at the beginning and end of each survey line and fits a gaussian curve to diagnostic photopeaks, such as the $\mathrm{Tl}^{208}$ peak at $2614.5 \mathrm{KeV}$ and the $\mathrm{K}^{40}$ peak at $1460 \mathrm{KeV}$ for low altitude lines and the annihilation peak at $511 \mathrm{KeV}$ and the $\mathrm{K}^{40}$ peak at $1460 \mathrm{KeV}$ for high altitude lines. The position of these photopeaks is determined with an accuracy of better than 0.1 of a channel and is used to determine the exact position of the energy windows with regard to channel numbers. At the same time the calculated standard deviations of the fitted gaussian curves serve to obtain the system resolution at the photopeaks used. The window count rates are normalized for live time and are calculated as follows:

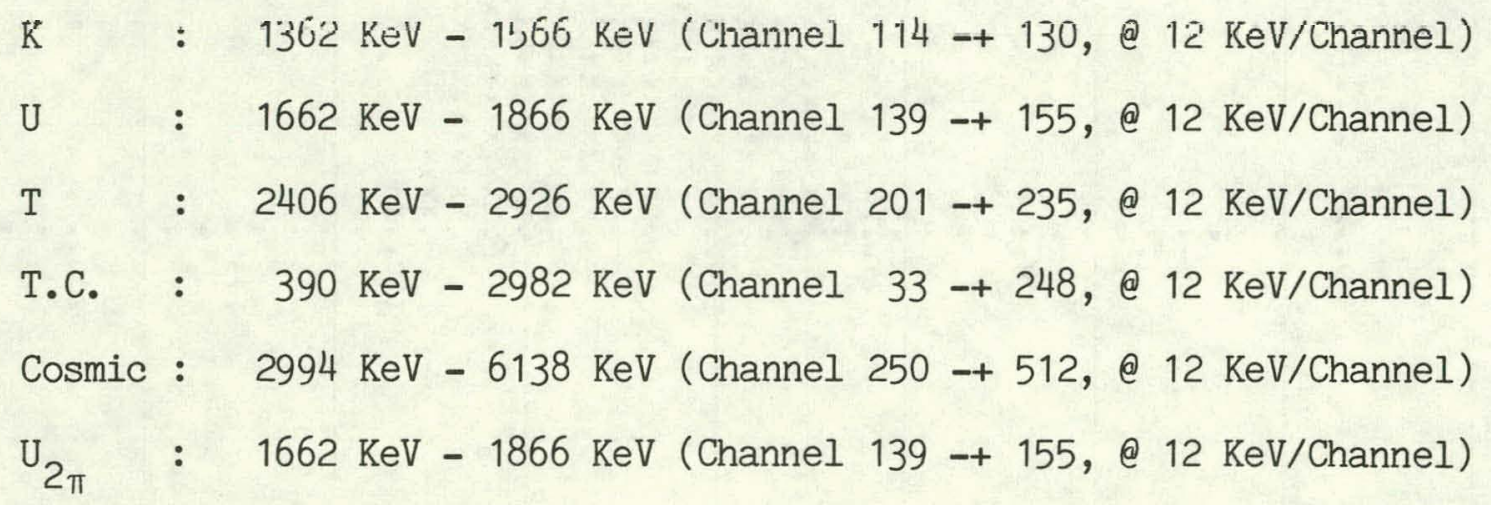




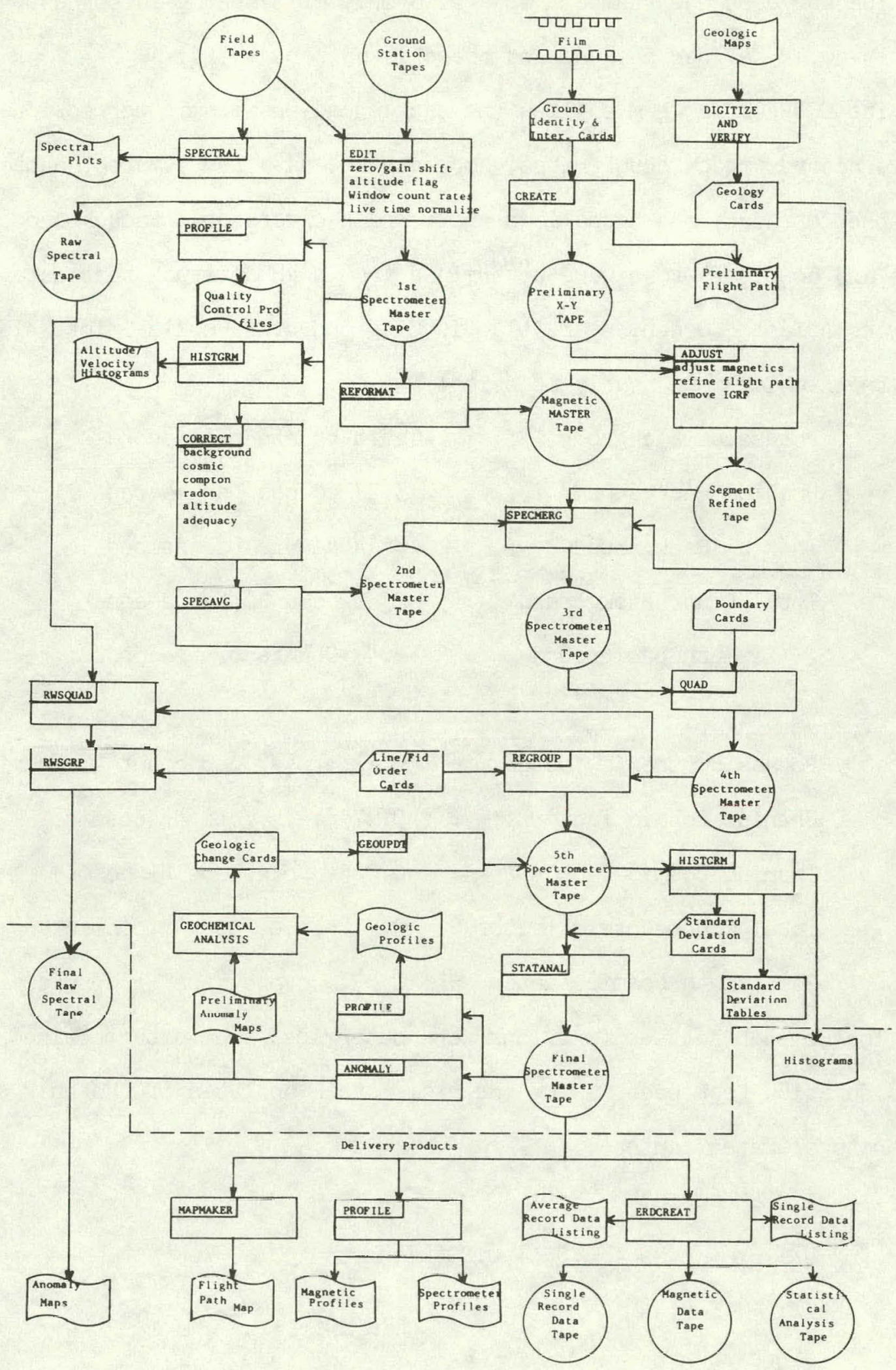


The above channel numbers are valid only if system gain corresponds exactly to $12 \mathrm{KeV}$ per channel and there is no zero shift.

The CORRECT program applies the background and cosmic corrections to the single record window count rates, corrects the data for Compton scatter and atmospheric radon, and normalizes the terrain clearance. Background count rates and cosmic factors were determined from high altitude test data acquired over the Atlantic Ocean, near Atlantic City and over Cook's Inlet, Alaska, the results of which were nearly identical:

$\begin{array}{ll}\text { Potassium Background } & =25.8 \text { counts per second } \\ \text { Uranium Background } & =5.27 \text { counts per second } \\ \text { Thorium Background } & =8.14 \text { counts per second } \\ \text { Total Count Background }= & 215.2 \text { counts per second } \\ 2 \pi \text { Bismuth Background } & =1.43 \text { Counts per second }\end{array}$

$$
\begin{aligned}
& \text { Potassium Cosmic factor }=0.22 \mathrm{c} \cdot \mathrm{p} . \mathrm{s} \cdot \text { per count } 4 \pi \text { cosmic } \\
& \text { Uranium Cosmic factor }=0.17 \mathrm{c} \cdot \mathrm{p} \cdot \mathrm{s} \cdot / \mathrm{cps} 4 \pi \text { cosmic } \\
& \text { Thorium Cusmic factor }=0.215 \mathrm{c} \cdot \mathrm{p} . \mathrm{s} . / \mathrm{cps} 4 \pi \text { cosmic } \\
& \text { Total Count Cosmic factor }=3.77 \mathrm{c} \cdot \mathrm{p} . \mathrm{s} . / \mathrm{cps} 4 \pi \text { cosmic } \\
& 2 \pi \text { Bismuth Cosmic factor }=0.0375 \mathrm{c} . \mathrm{p} . \mathrm{s} . / \mathrm{cps} 4 \pi \text { cosmic }
\end{aligned}
$$

The Compton scatter functions were detcrmined from data obtained nver the Grand Junction test pads, using the radiometric analysis of the bulk sample with natural water content.

$$
\begin{aligned}
& T / U=\tau=0.07 \\
& U / T=\alpha=0.35+0.02+0.000076 H \\
& K / T=\beta=0.44 \\
& K / U=\gamma=0.99
\end{aligned}
$$

The $2 \pi$ and $4 \pi$ uranium window count rates are related through the 
geometric or equivalency factor. For the present system, installed in the Sikorsky S-58T helicopter, this factor, $\mathrm{f},=5.75$. Part of the terrestrial radiation of energy higher than $1662 \mathrm{KeV}$ - the lower threshold of the uranium window - is detected in the uranium window of the upward looking detector, due to imcomplete shielding, skyshine and shine-around. This shine-through/shinearound effect is assumed to be a function of both the intensity of the terrestrial uranium and thorium radiation and of the aircraft terrain clearance. From multi-altitude data acquired over the Lake Mead Dynamic Test Range the shine-through/shine-around effect was determined for each altitude level. The data provided a best fit for an exponential terrain clearance function as follows:

$$
\text { shine-through/shine-around }=0.06\left(U_{4 \pi}+0.35 \mathrm{~T}_{4 \pi}\right) \mathrm{e}^{-7.0 \times 10^{-4} \mathrm{H}}
$$

The shine-through/shine-around corrected Biair Count rate is then:

$$
U_{2 \pi c}=U_{2 \pi}-\frac{\left(U_{4 \pi}+0.35 T\right) 0.06 \times e^{-7.0 \times 10^{4} H}}{\left(1-5.75 \times 0.06 \times e^{-7.0 \times 10^{4}}\right)}
$$

The shine-through/shine-around correction is applied to the $\mathrm{U}_{2 \pi}$ count rate at each single record. The single record $U_{2 \pi}$ count rates are then averaged over 35 records to make them statistically compatible with the data of the primary system. Ihe atmospheric radon correction is applied to both the $\mathrm{U}_{4 \pi}$ and the Total count count rates. The equivalency factor for the $\mathrm{U}_{4 \pi} / \mathrm{U}_{2 \pi}=$ 5.75, for Total Count $/ \mathrm{U}_{2 \pi}$ it is 80 .

Within the CORRECT program the data are normalized to a common datum of 400 feet terrain clearance. An exponential formula is used, based on an air column reduced to a standard temperature and pressure of $0^{\circ} \mathrm{C}$ and $760 \mathrm{~mm} \mathrm{Hg}$. $\left(32^{\circ} \mathrm{F}\right.$ and $\left.29.92^{\prime \prime} \mathrm{Hg}\right)$. The air absorption coefficients used are those derived from the multiple altitude flight over the Lake Mead Dynamic Test Range for thorium, potassium and Total Count. The air absorption factor for uranium is 
obtained by straight interpolation between the potassium and thorium air absorption factors. Their values are respectively:

$$
\begin{aligned}
& H_{K}=2.71 \times 10^{-3} \text { per foot } \\
& H_{U}=2.55 \times 10^{-3} \text { per foot } \\
& H_{T}=2.10 \times 10^{-3} \text { per foot } \\
& H_{T C}=2.12 \times 10^{-3} \text { per foot }
\end{aligned}
$$

The formula used for the altitude normalization is:

$$
\mathrm{N}_{400}=\mathrm{N}_{\mathrm{H}} \cdot \mathrm{e}^{-\mu\left(400-\frac{273}{273+\mathrm{t}}\right.} \cdot \frac{\mathrm{P}}{29.92} \text {. }
$$

Where $\mathrm{N}_{400}, \mathrm{~N}_{\mathrm{H}}$ are respectively the count rates at 400 feet and at altitude $\mathrm{H}, \mu$ is air absorption factor, $\mathrm{t}$ is temperature in degrees Celsius and $\mathrm{P}$ is barometric pressure in inches $\mathrm{Hg}$.

The last operation in the CORRECT program is the determination of statistical adequacy of the data. The criteria for adequacy of the data are based on the work of Lloyd A. Currie (op.cit.). A critical level is recognized, below which all observations made fail to detect a signal, i.e. $95 \%$ of all measurements fall within the "normal" distribution of "noise". The detection level is similarly defined as the level above which $95 \%$ of the measurements made fall within the normal Poisson distribution of "signal". Currie's critical level has been adopted as the count rate level below which data are inadequate. Data with count rates above the critical level but below the detection level are considered marginal. Above the detection level data are considered adequate. For the single record data the formulas are then: Count Rate $<2.33$ (Sum Corrcctions) ) $^{1 / 2}$ : data inadequate 2.33 (Sum Corrections:) ${ }^{1 / 2}$ Count Rate $<2.71+4.65$ (Sum Corrections) ${ }^{1 / 2}$ : data marginal

Count Rate > $2.71+4.65$ (Sum Corrections $1 / 2$ : data adequate

No ratios have been calculated involving inadequate data in either numerator or denominator. Ratios have been calculated when the data in the numerator are marginal, provided the data in the denominator are adequate. 
The thorium, uranium and potassium data are subsequently averaged over 9 records in the SPECAVG program. The output is a spectrometer master tape containing both averaged and single record data.

Parallel with the radiometric data reduction process, the magnetic data are edited and processed. Using the recovered film intersections and the established ground identities, preliminary flight paths are prepared. The flight path is refined in the magnetic adjustment program until an accurate final flight path has been obtained. The reduced spectrometer data are then merged with the final $\mathrm{X}-\mathrm{Y}$ position of the data points, the reduced magnetic data and the digitized geology, and a master tape is produced with data that pertain to each $3^{\circ} \times 1^{\circ}$ NTMS quadrangle only. The REGROUP program then eliminates all duplicate line segments, orders the remaining line segments and renumbers the fiducials on the flight lines.

The following processing steps are STATANAL and HISTGRM. HISTGRM groups the radiometric data by geological cell units, determines the distribution of the data as normal or lognormal, calculates the mean (for normally distributed data) or the mode (for lognormal distributions) as well as the standard deviations. The results from HISTGRM are used in the STATANAL program, which calculates the signed standard deviation from the mean for each averaged sample for each of the six radiometric parameters. Its output is the Final Spectrometer Master Tape, from which the anomaly maps, the statistical analysis tape, the averaged record and single record reduced data tapes and listings, the flight path maps and the radiometric and magnetic profiles are produced. 


\section{DATA PRESENTATION}

\section{General}

The final data are presented in four different forms: on magnetic tape; on microfiche; in graphic form as profiles and histograms; and in map form as anomaly maps, flight path maps, and computer printer maps.

The histograms and the multiparameter profiles are presented with the anomaly maps and flight path map in a separate bound volume. Completc data listings of both the reduced single renord and the reduced averaged record data are found in the back of this report. The format of the printout of the microfiches and the format of the magnetic tape is in accordance with the specifications of the BFEC $1200-\mathrm{C}$ and is described in appendices $\mathrm{A}$ through $\mathrm{N}$ of this report.

\section{Radiometric Multiple-Parameter Stacked Profiles}

The radiometric profiles have been prepared at the horizontal scales of $1: 250,000$ and $1: 500,000$ on an automated flatbed plotter. Displayed are from top to bottom: total magnetic intensity, IGRF remover, in gammas; radar altimeter, in feet; ratio of $\mathrm{eT}$ concentration in ppm/potassium concentration in \%; ratio of $\mathrm{eU} / \mathrm{K}$; eU/eT ratio, atmospheric radon (BIAC) in counts per second, equivalenced to the $4 \pi$ count rate; apparent concentration of terrestrial eT in ppm, apparent concentration of terrestrial eU in ppm; apparent concentration of potassium in \%; "Total Count" count rate. Flags are indicated, wher' needed, below the base line of the correspunding parameter. A short flag indicates marginal data, including terrain clearances between 700 and 1000 feet, while a long flag indicates inadequate data. Fiducial markers are plotted every 200 records, along the top of the profile, every 10 records along the bottom.

Geologic formations are shown on the bottom of the radiometric and mag- 
netic multiple-parameter stacked profiles below the fiducial markers. Six tiers of formation identifiers along with short markers are used to indicate changes along the profile with the base of the identifier letters aligned with the corresponding marker. The first identifier found on the westernmost end of the profile applies to the start of the line and this formation continues until the next marker is encountered. Subsequent changes to the geology are similiarily indicated along the profile.

\section{Magnetic and Ancillary Parameter Stacked Profiles}

The magnetic profiles have also been plotted at scales of $1: 250,000$ and $1: 500,000$ on an automated flatbed plotter. The plotting sequence of the profiles is, from top to bottom: barometric pressure at aircraft altitude in inches Hg; atmospheric ambient temperature in degrees Celsius, terrain clearance in feet; magnetic variations at base station, in $\frac{1}{4} \gamma$ less a 50,000 $\gamma$ bias; total magnetic intensity, IGRF removed, in gammas. Fiducial markers are again plotted every 200 records along the top of the profiles, every 10 records along the bottom.

\section{Histograms}

Histograms have been prepared for the six radiometric parameters for each geologic cell unit of the NTMS quadrangle area. The horizontal scale of the plots is constant for each of the parameters. Frequency grouping has generally been done in 100 groups per full scale, although in some cases more groups may have been used for better definition. In all cases the vertical scale was normalized to the number of samples observed in the group with the highest sample frequency.

For each hislogram the frequency distribution type (normal or lognormal) is listed, as well as the mean (or mode in case of lognormal distribution) and the signed standard deviations. Note that for both the normal and lognormal distribution ourves the standard deviation is given in terms of the parameter 
value $(\mathrm{K}, \mathrm{eU}, \mathrm{eT}, \mathrm{eU} / \mathrm{K}, \mathrm{eU} / \mathrm{eT}$ and $\mathrm{eT} / \mathrm{K})$. The actual standard deviation is obtained by subtracting the mean parameter value from the +1 standard deviation figure in case of a normal distribution, by dividing the mode value into the +1 standard deviation figure in case of a lognormal distribution. In case of lognormal distribution curves the standard deviation is thus a multiplication factor.

Each histogram further lists the total number of samples observed in the geologic unit and the number of statistically adequate/marginal data samples in each parameter plot.

\section{Anomaly Maps}

The anomaly maps have been prepared at scales of 1:250,000 and 1:500,000 on an automated flatbed plotter. The fiducial numbers along the flight lines match those of the corresponding profiles. Positive signed deviations of the mean are indicated by a plus sign to the north or west of the flight lines, while negative signed deviations are indicated by a minus, plotted to the south or east of the line. The number of pluses or minuses corresponds with the levels of standard deviation from the mean. To avoid cruwdiny standard deviation signs are calculated and plotted for every fifth sample only.

\section{Computer Printer Maps}

Computer printer plots are produced for the total field and the six radiometric channels. Upper and lower limits were chosen based on the minimum and maximum values of the gridded data. Ten intervals are represented by the contour values 0 to 9. A minus (-) or a plus (+) sign represents those values less than the lower limit or those values higher than the upper limit.

The interval for each integer contour is further divided into two groups. For those values less than .5, the contour is printed; e.g. for values 4.0 to 4.5 , the value 4 is printed, while values of 4.6 through 4.9 are left blank. 
GEOLOGY

\section{Introduction}

The Iditarod quadrangle is located in the southwestern part of Alaska. The northern and southern boundaries of the quadrangle sheet are latitude $63^{\circ} 00^{\prime}$ north and latitude $62^{\circ} 00^{\prime}$ north, and the eastern and western boundaries are longitude $156^{\circ} 00^{\prime}$ ' west and longitude $159^{\circ} 00^{\prime}$ 'west, respectively.

The Iditarod River and its tributary, Bonanza Creek, flow across the map sheet toward the southwestern part of the quadrangle, eventually draining northward off the area of the map sheet. In the southeastern corner, the Kuskokwim River crosses the quadrangle, flowing southward.

In the south-central part of the map sheet, there is an upland area forming a portion of the Kuskokwim Mountains. The general elevation of the Kuskokwim Mountains in this region is about two thousand feet above sea level. Adjacent lowland areas are on the order of one thousand feet above sea level. In the northeast-center, the Beaver Mountains, a small mountain range oriented northwest-southeast, attain elevations in excess of three thousand five hundred feet above sea level.

Most of the Iditarod quadrangle is covered with vegetation, presumably forest. Along the course of the Iditarod River in the west there are swampy areas, and in the northwestern part of the map sheet (between the Iditarod and Yetna Rivers) ground elevations are less than two hundred feet above sea level and there is a large marshy area.

It should be noted that across the map sheet, from the southwestern corner to the nurtheastern corner there is a chain of rivers and creeks (the Iditarod River, flowing northeastward; its tributary, Bonanza Creek, flowing southwestward; and Fourth of July Creek, flowing northeastward) which form dri unusually straight line in a region where meandering drainage is more 
characteristic. These streams, and a few others on the sheet, are apparently controlled by faulting.

The only towns on the quadrangle that are apparently inhabited at the present time are Discovery and Moore Creek, in the central part of the sheet.

The geology of the Iditarod quadrangle was compiled by ESCA-TECH Corporation, of Costa Mesa, California, from pre-existing publications of the U. S. Geological Survey, the Alaska Geological Survey, and it was supplemented by study of Landsat imagery.

\section{Stratigraphy}

Within the area of the Iditarod quadrangle, seventeen discrete rock units have been recognized and delineated. These include an undifferentiated metamorphic basement, four sedimentary units (one of which includes a contact metamorphosed facies), a Quaternary alluvial unit and a Quaternary "mine tailings" unit. The latter's inclusion as a valid geologic rock unit is dubious. Ten igneous rock units have been recognized.

The followjing brief description of the rook units mapped on the quadrangle is subdivided by rock class (metamorphic, sedimentary and metasedimentary, and igneous rocks) and within each class they are arranged chronologically beginning with the oldest.

\section{Metamorphic Rocks}

Undifferentiated metamorphic rock (Ppc)

Pre-Cambrian/Palcozoic (Age uncertain) Sedimentary (and Metasedimentary) Rocks

Chert, minor limestone and quartz sandstone (PC) Possibly Mississippian in age. 
Slightly metamorphosed sedimentary rocks (Pz)

Paleozoic in age.

Chert and argillite, calcareous sandstone, and locally fossiliferous

limestone $(\mathrm{Kc})$

Lower Cretaceous in age.

Kuskokwim Group ( $\mathrm{kk}$ and $\mathrm{Kkh}$ )

Undifferentiated siltstone; shale, sandstone and conglomerate. The contact metamorphosed phase is hornfels $(\mathrm{Kkh})$. The age of the formation is upper Cretaceous.

Quaternary alluvium (Qal)

Undifferentiated surficial deposits.

Quaternary mine tailings (Qmt)

Igneous Rocks

Siltstone, chert, tuff and pillow flows (MzPz)

Paleozoic and Mesozoic (age uncertain).

Basalt flows underlain by sedimentary breccia (Mzv)

Paleozoic and Mesozoic (age undertain).

Monzonite, monzodiorite and tonalite, locally quartz monzonite and granodiorite (Km)

Upper Cretaceous in age.

Basalt to andesite flows, minor gabbro (Kba)

Upper Cretaceous in age.

Basaltic agglomerate flow breciia (kl)

Upper Cretaceous in agc.

Dacite, rhyolite, and basalt dikes and sills (TKV)

Cretaceous and Tertiary in age.

Granite to quartz diorite (TKgd)

Cretaceous and Tertiary in age. 
Pyroxene diorite, gabbro, pyroxenite, diabase (Tmi)

Tertiary in age.

Albite rhyolite (Tr)

Tertiary in age.

Basaltic and andesitic flows (QTV)

Tertiary and Quaternary.

Rocks of the Kuskokwim group (Kk) crop out across about sixty percent of the map sheet area. In the northwest, older, undifferentiated metamorphic rocks (Ppc) are widely exposed, overlapped by the Quaternary alluvium (Qal) of the marsh in the northwest. The complex igneous suite is primarily exposed in smaller areas in the northeast. The largest igneous complex forms the Beaver Mountains.

\section{Strirture}

The Iditarod quadrangle is located on the flank of a major structural depression nanted Lle Kuskokwim Ccosyncline. 'l'he gensyclinal dxis strikes north $50^{\circ}$ east-south $50^{\circ}$ west, and this regional geologic trend is in agreement with the mapped geology of the quadrangle.

The most prominent structural feature on the map sheet is a long, continuous fault extending from the southwestern curner of the map to the northeastern corner along the valleys of the Iditarod River, Bonanza Creek and Fourth of July Creek. The feature is named the Iditarod-Nixon Fault. A large number of linear features have been delineated from photographic coverage (and presumably Landsat imagery as well) and it is inferred that these are the surficial expressions of faults. In general, they are oriented northeast-southwest, consistent with the regional strike and the Iditarod-Nixon 
Fault. Their surficial expression is typically long, straight stream valleys in a region where extreme drainage meandering is to be expected.

In the northwestern corner of the quadrangle, metamorphic rocks of the pre-Cambrian/Paleozoic basement (PPc) are exposed. These rocks form the edge of the positive area northwest of the Kuskokwim Geosyncline. A photolinear is delineated along the margin of the metamorphic terrain, suggesting that the boundary between the two structural provinces is a profound fault or fault system.

stroks, bosses, dikes and extrusions of generally felsic composition are distributed across the map sheet. The most widely distributed of these are monzonites, granites, quartz diorites and associated basalts and gabbros. They appear to be intrusive into the upper Cretaceous Kuskokwim Group in most places. The most prominent igneous complex on the Iditarod quadrangle is in the northeast, underlying the Beaver Mountains.

\section{Economic Geology}

A number of mines are noted in the Kuskokwim Mountains within the area covered by the Iditarod quadrangle. Their ores are not identified; however, those near the town of Discovery are described on the topographic map as "placer mines", suggesting that they are gold workings. 


\section{INTERPRETATION}

\section{General}

The airborne gamma ray spectrometer survey is conducted as part of the Department of Energy's National Uranium Resources Evaluation (NURE) program. The primary purpose of the survey is regional resource evaluation rather than the recognition of discrete local anomalies. The interpretation of the radiometric data is directed towards determining zones of possible depletion of uranıum minerals which may have served as possible uranium sources, outlining areas of local enrichment in uranium and indicating the geological formations which are most likely to be mineralized within a potential uranium province.

The areas of possible depletion or enrichment are outlined with the aid of the anomaly maps. Enrichment or depletion on a regional scale is assumed to have taken place if the uranium/thorium and uranium/potassium ratio values remain higher or lower than at least one standard deviation above or bclow the mean for a distance of at least a mile, provided the potassium, uranium and thorium count rates are at the same time not less than one standard deviation below the mean. One mile corresponds to approximately thirty-five samples.

The probability of a geologic rock unit being mineralized by a given element may be estimated from the dispersion of the geochemical distribution of that element within the formation. The narrower the distribution curve (i.e., the smaller the ratio of the standard deviation over the mean) the less likely it is that an extremely high concentration of that element is present within that formation, and vice versa.

Recognition of the prospective aspects of a formation and of the presence of a regional geochemical anomaly is influenced greatly by the selection of the appropriate geological cell units used in the correlation 
of the radiometric and geologic data. The radiometric parameters used in this report are concentrations in parts per million of equivalent uranium and equivalent thorium, in percentage of potassium, and their comparitive ratios. The radiometric count rates of the helicopter-borne A. G. R. S. (Airborne Gamma Ray Spectrometer) system were calibrated at the Lake Mead Dynamic Test Range against sources of known concentrations of potassium, uranium and thoriuin. The sensitivities of the A. G. R. S. system, normalized to four hundred feet terrain clearance at standard temperature and pressure are:

Radioactive element

Potassium

Uranium

Thorium

\section{Count rate}

$95.26 \mathrm{cps}$

$\cdot 9.92 \mathrm{cps}$

$6.26 \mathrm{cps}$

\section{Concentration}

$1.0 \% \mathrm{~K}$

1 ppm eU

1 ppm eTh

Geochemical Analysis

A total of seventeen geologic units have been mapped in the Iditarod Quadrangle. Three sedimentary units (Kuskokwim hornfels, lower Cretaceous chert and argillite and the undifferentiated Paleozoic metasediments) along with an igneous unit, the upper Cretaceous basalt breccia, were not overflown in the course of the survey. Two of the mapped rock units, Quaternary alluvium (Qal) and upper Cretaceous basalt/andesite (Kba) have been subdivided. This subdivision was accomplished by preparing a pseudo-anomaly map on which samples falling under distinguishable count rate peaks were assigned arbitrary standard deviation values.

Fifteen of the stratigraphic units traversed in the course of the airborne survey were analyzed statistically. In addition to these histogram sets, a set of histograms was prepared for the gamma radiation responses over 
rivers and streams, and the Quaternary alluvium (Qal) has been separated into "wet" and "dry" phases.

Of the sedimentary formations, the Kuskokwim group siltstones, shales and sandstones (Kk) statistical analyses display well developed normal histogram distribution curves in all spectral windows. In view of the wide exposure of the formation (about sixty percent of the map sheet area) it is likely that the regularity of the histogram distribution and its breadth is attributable to the abundance of samples, with negligible change in the all-inclusive äistribution curves as a result of local radioactive anomalies, rather than an extermely homogeneous formation.

The Quaternary alluvium (Qal), both "dry" and "wet" phases, display narrow, well defined histogram peaks and steep count distribution curves. As is to be anticipated, the "dry" phase reveals higher count distribution concentrations in all spectral windows than does the "wet" phase.

The Paleozoic chert, limestone and quartz sandstone formation (PC) displays irregular histogram distribution curves, with a strong suggestion of dual peaks. 'Ihe dual peaks indicate that two sedimentary factes are exposed, possibly the chert and the sandstone. However, the number of samples is extremely low (seventy-four) so that it is not possible to consider the analysis conclusive.

The Quaternary "mine tailings" (Qmt) also provided insufficienl sanpling and erratic curves. It is assumed that mine trailings have been considered with regard to mineralization in the course of the mining process, so that their inclusion in this study is academic.

The undifferentiated metamurphic basement, widely exposed in the northwestern part of the quadrangle, displays broad, log normal histogram distribution curves on all three spectral windows. The curves are irregular, 
especially in the higher volumetric concentrations and there is apparent dual peaking in the thorium window and a suggestion of dual peaking in the potassium window. The irregularity of the curves and the "tailing" into the higher concentrations probably reflects the heterogeneity of the metamorphic basement complex $(\mathrm{Ppc})$. This all-inclusive unit undoubtedly consists of more than one distinct rock facies. In all probability, the zones of strong gamma radiation observed on Traverse 560 (fiducials 4840-4880 and 5030-5090), Traverse 580 (fiducials 1600-1700) and Traverse 640 (fiducials 770-910) are the sources of the tailing and incipient dual peaking on the histograms.

Most of the igneous rock units outcropping in the Iditarod quadrangle have very small exposure areas and therefore were not sufficiently sampled to permit reliable statistical analysis. In general, these formations were erratic in their distribution. The Cretaceous/Tertiary dacite, rhyolite and basalt dikes and sills (TKv) yields irregular histogram distribution curves, indicating that the rock unit consists of several components. This is consistent with the formation description which suggests wide compositional variation. The same is true of the upper Cretaceous basalt to andesite flows (Kba), which also yield erratic histogram distribution curves on all spectral channels. The original histograms exhibit complex distributions although the ratio histograms are relatively well defined. The formation has been subdivided into a basaltic unit (KBB) which expresses the large flow located at the intersection of Traverse 600 and Tie 1 ine 5120 and an andesitic unit (KA) which includes all other exposures of the mapped rock unit. In contrast, the older basalt flows underlain by sedimentary breccia (Mzv) are characterized by relatively narrow, well defined histogram distribution curves in the uranium and thorium spectral channels although there is a dual peak in 
the potassium channel. These curves suggest that the older basalt flows, which outcrop in one large exposure in the southwest adjacent to the Iditarod-Nixon Fault, were extruded in a relatively brief cycle and are quite homogeneous in composition.

\section{Anomaly Map Analysis}

Anomalous radioactivity. levels are encountered in nine locations on the Iditarod quadrangle, on both the uranium and thorium spectral windows. Three of these are relatively restricted, discrete anomalous features. The other six are in two groups of comparitively long intervals variably high in uranium and thorium series radiation, and. they are aligned in such a manner as to suggest that their source is in a length zone or formation enriched in uranium and thorium mineralization.

On Traverse 500 (fiducials 6340-6400), Traverse 520 (fiducials 28603280), Traverse 540 (fiducials 7600-7820) and Traverse 560 (finincials 6260-6290), intervals of increased gamma radiation are present. The anomalous radiation is most pronounced in the uranium and thorium spectral windows. The intermittent zones of increased gamma radiation on Traverses 500, 520 and 540 are correlated with mapped exposures of upper Cretaceous monzonite $(\mathrm{Km})$ and the various related rocks; tonalite, quartz monzonite, granodiorite, etc. Increased radioactive level is to be anticipated over exposures of felsic rock; however, the anomalies are unusually intense on Traverse 520 and on Traverse 540. On Traverse 560, the single anomalous interval corresponds to an exposure of Cretaceous and Tertiary granite and quartz diorite (TKqd). The two rock units ( $\mathrm{Km}$ and TKqd) are mapped separately, however, their distribution and their spatial relationships to other rocks of the igneous suite suggests that they may be related if 
LEGEND TO TOTAL FIELD GAMMAS MAP

\begin{tabular}{ccc} 
& LOWER LIMII & UPPER LIMIT \\
\hline & & 54850.0 \\
1 & 54950.0 & 55000.0 \\
2 & 55000.0 & 55150.0 \\
3 & 55150.0 & 55300.0 \\
4 & 55300.0 & 55450.0 \\
5 & 55450.0 & 55600.0 \\
6 & 55600.0 & 55750.0 \\
7 & 55750.0 & 55900.0 \\
8 & 55900.0 & 56050.0 \\
9 & 56050.0 & 56350.0 \\
+ & 56200.0 & \\
\hline
\end{tabular}


$\begin{array}{lll}3334 & 333\end{array}$

$\begin{array}{lll}444 & 444 & 3333\end{array}$

$444 \quad 33333$

$\begin{array}{ll}4 & 3 \\ 33 & 333\end{array}$

$.2233 \quad 3 \quad 333$

333333
3333

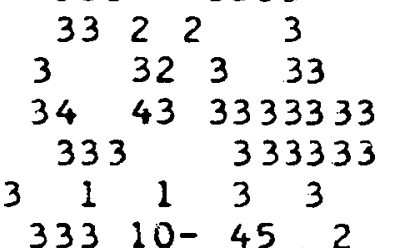

$33310-45 \cdot 2$ 3333333
33333333
33333333
333333
33333333 33333 . 
LEGEND TO POT AVGE MAP HCT

\begin{tabular}{ccc} 
CONTOUR VALUE & LOWER LIMIT & UPPER IIMIT \\
0 & & 0.3 \\
1 & 0.3 & 0.6 \\
2 & 0.6 & 0.9 \\
3 & 0.9 & 1.2 \\
4 & 1.2 & 1.5 \\
5 & 1.5 & 1.8 \\
6 & 1.8 & 2.1 \\
7 & 2.1 & 2.4 \\
8 & 2.4 & 2.7 \\
9 & 2.7 & 3.0 \\
+ & 3.0 & 3.3 \\
\hline
\end{tabular}




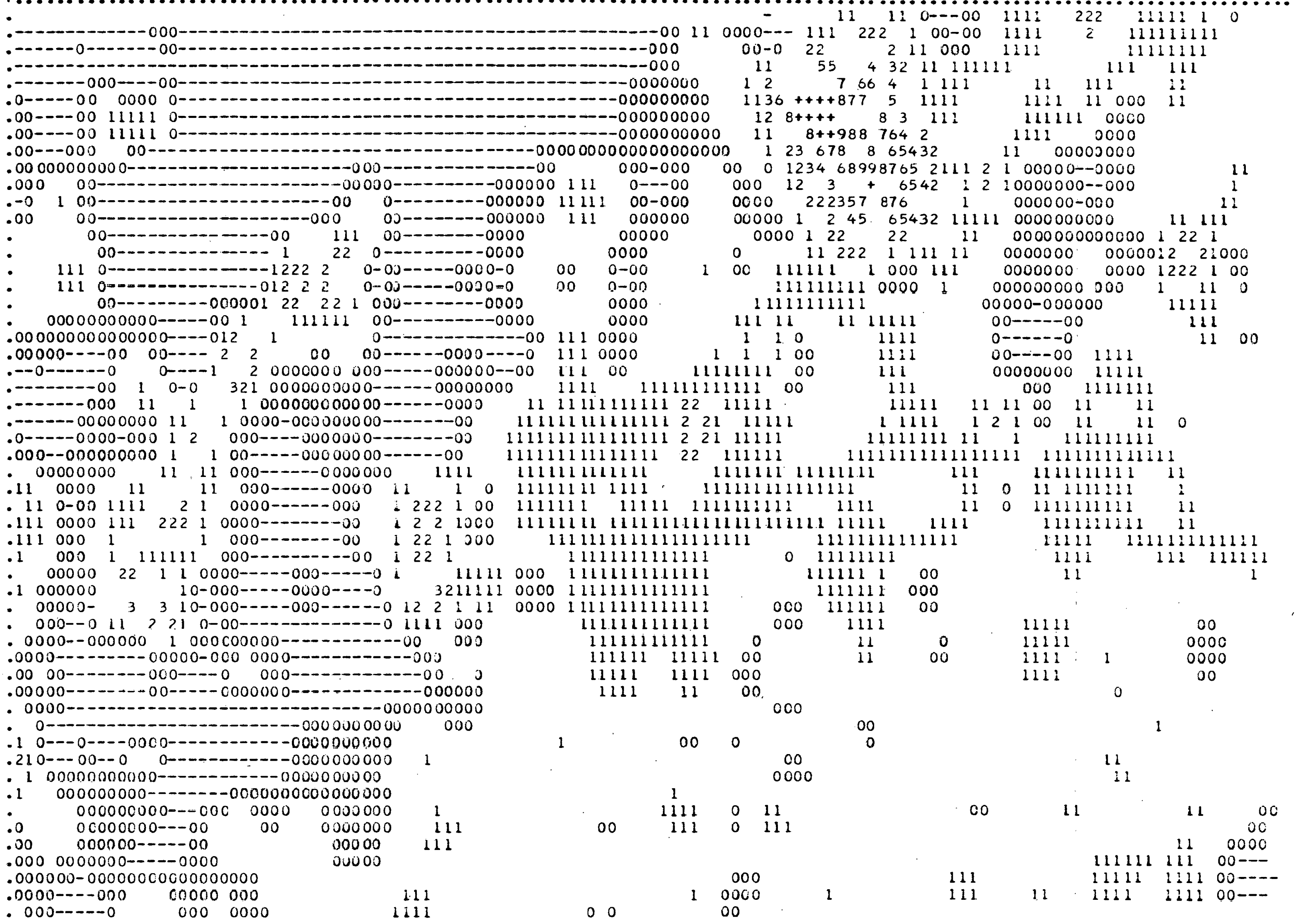


LEGEND TO URN AVGE MAP PPM

\begin{tabular}{ccc} 
& & UPPER LIMIT \\
\hline & & 0.7 \\
1 & 0.7 & 1.4 \\
2 & 1.4 & 2.1 \\
3 & 2.1 & 2.8 \\
4 & 2.8 & 3.5 \\
5 & 3.5 & 4.2 \\
6 & 4.2 & 5.9 \\
7 & 4.9 & 6.2 \\
8 & 5.6 & 6.9 \\
9 & 6.2 & 7.6 \\
4 & 6.9 & \\
- & 7.6 &
\end{tabular}


$-00000 \quad 00--0 \quad 0000000--000-0-00000000000000000000$

$.000000 \quad 0-000 \quad 00000000--000-\ldots+\ldots-0-000---00000000000000$

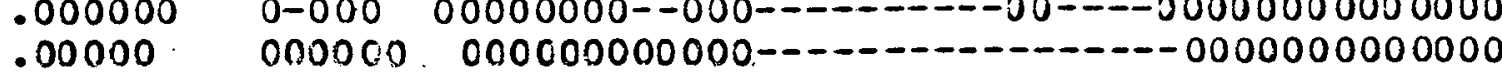

0000 000000---000--- $000---00000000000000$

$1000000000----00--0000000---0000000000000$

$\therefore 1001111111000000---0--00000000400000--00000000000000$

$.100111111000000---00-00000000000000--00000000000000$

$.1 \quad 1111000 \quad 00000---000000000000000----0000000$

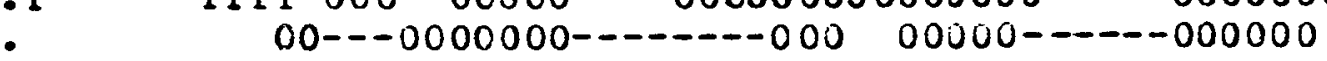

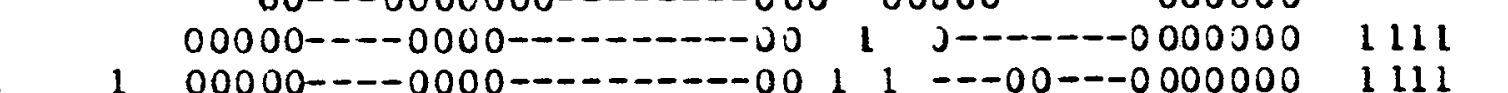

$00000--0000--0-001111--000--0000000 \quad 1111$

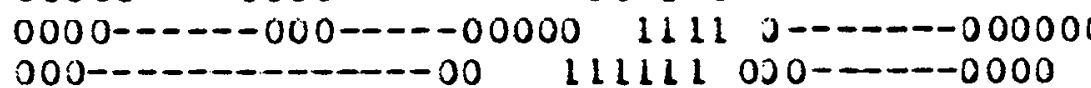

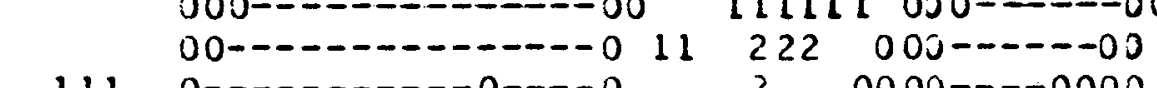

- 111

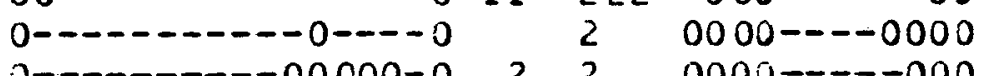

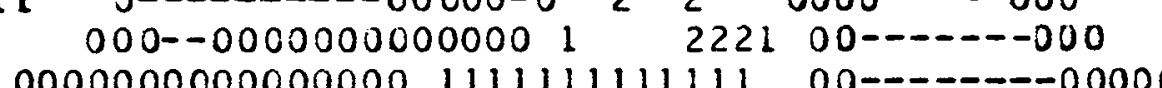

$111111^{111} 22^{2} 1111111111$

$11+111$

$0000000000000000111111111111100----0000000$

$.0000--00 \quad 000-012331 \quad 00000---0000--001111000$

$.000-001000-01233$ 1 $00-01233$ 1 $0000000----000000000011$

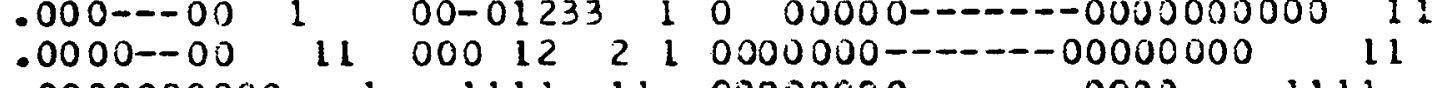

$.0000000000110001111{ }_{11} 00000000-\cdots-0000 \quad 1111$

$.000-00000001111,000000-000-----0000111$

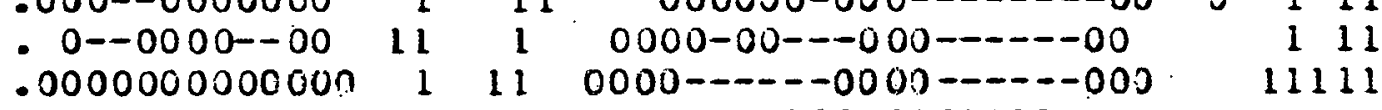

- 0000000000 11111 $000----00000000000$

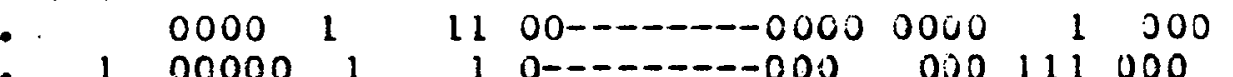

- $10000011 \quad 100----0000000111000$

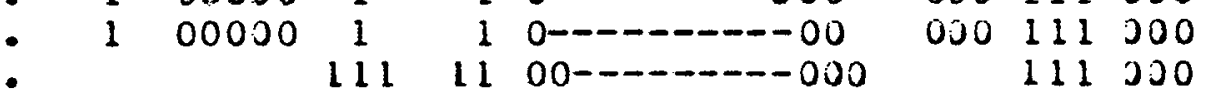

$.1100011111111000-0-00001111$

$.20000012 \quad 20-0 \quad 00-00000-0-00222111100011111111111$

$1000001111 \quad 1000000000000---00111100$

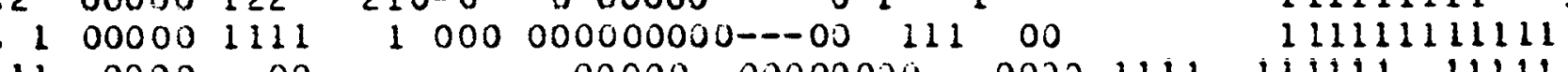

$1100000000000-0000000000301111$ 111111 1111

$\begin{array}{lllllll}00000000000000 & 00--000000000 & 00 & 1111 & 1111 & 1111 \\ 01 & 00000000000--0 & 00--0000--0000000 & 1111 & 111 & 1111\end{array}$

$00--0000000000000-0$ 11111 11111

$0000000-10000000000000000000000000000000$

- $0000000---0000000 \mathrm{C}-000--000$

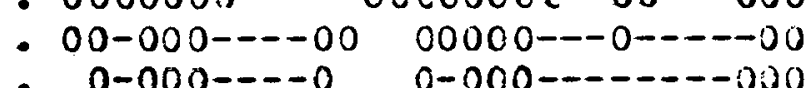

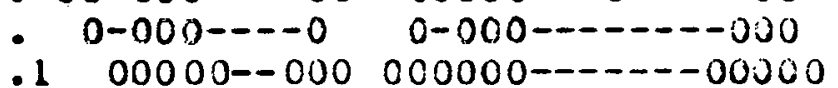

$100000--000000000-1000000000000$

0006000 00000000000000000

$.0100 \quad 0000000000000000000000$

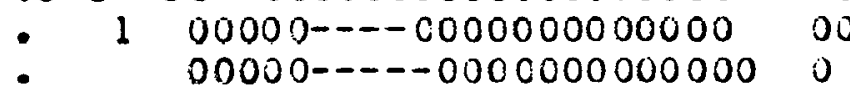

$.000000000--10000000000000$

$0000000000--00000000--000000000000$

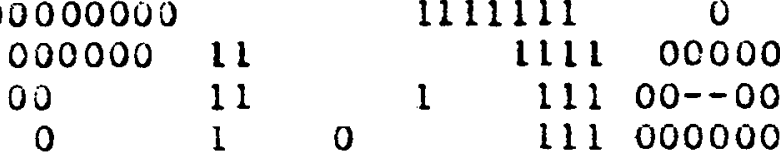

00

1

000

$\begin{array}{lllll}1 & 0 & & & 00000 \\ 11 & 00 & 00 & 11 & 0-00\end{array}$

$000000 \quad 00000$ $00-0000 \quad 0000000$

$\begin{array}{lllllll}12 & 3322 & 2112111111 & 11 & 111111111\end{array}$

1110640 lil lililili

$111288^{++} 777 \quad$ l li1111111 00 il

$111127^{8} 877^{7} 22 \quad 1111111$

$00^{12} \begin{array}{rrrrrr}5677 & 34567 & 2 & 11111 & 000000000 & 0 \\ & 3456211 & 0000000-00 & 000\end{array}$

$\begin{array}{llllll}0 & 2247765421 & 1 & 00000-00000 & 000\end{array}$

$0000000 \quad 23465321,000000000000 \quad 11100$

$00000-001122.22^{3} 1111111000000001111$

$00-001 \quad 1111111110-000 \quad 10122111$

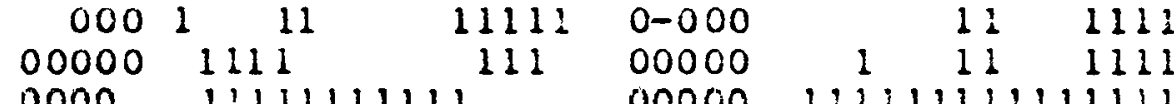
1111111111111 00000 111 ilil 0000000 12111211111 $000111 \quad 11$ il 111 110000000 il 1111 00011111 11 1112000000011111111 11111110000011111111 $1111111 \quad 111100000 \quad 1111$

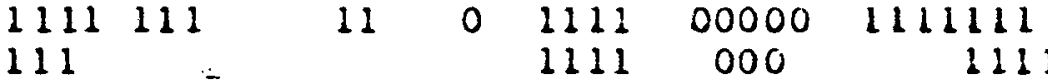
000 111111 $000 \quad 1$ 111111 1111111111111 111 000 11 11 11111 11111111 il li11 0000 lillitiditl 00011111111111
001111111111 111111111 1 000 11111 0112 111

1 11111111111111

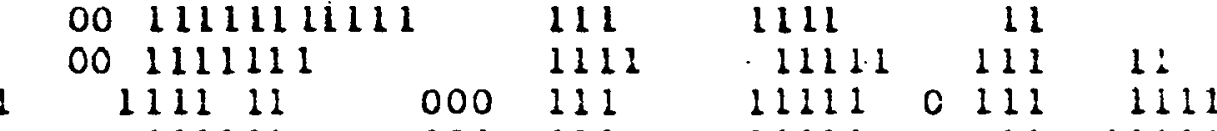
000 lilil 000 lilil lililil (1) $\begin{array}{lll}1111 & 11 & 00 \\ 111 & 000\end{array}$ $111 \quad 11000$

$$
+\ldots
$$


LEGEND TO THOR AVGEMAPPPM

\begin{tabular}{ccc}
\hline CONTOUR VALUE & LOWER LIMIT & UPPER LIMIT \\
\hline 0 & & 1.0 \\
1 & 1.0 & 2.6 \\
2 & 2.6 & 4.1 \\
3 & 4.1 & 5.7 \\
4 & 5.7 & 7.2 \\
5 & 7.2 & 8.8 \\
6 & 8.8 & 10.3 \\
7 & 10.3 & 11.9 \\
8 & 11.9 & 13.4 \\
9 & 13.4 & 15.0 \\
+ & 15.0 & 16.5 \\
\hline
\end{tabular}




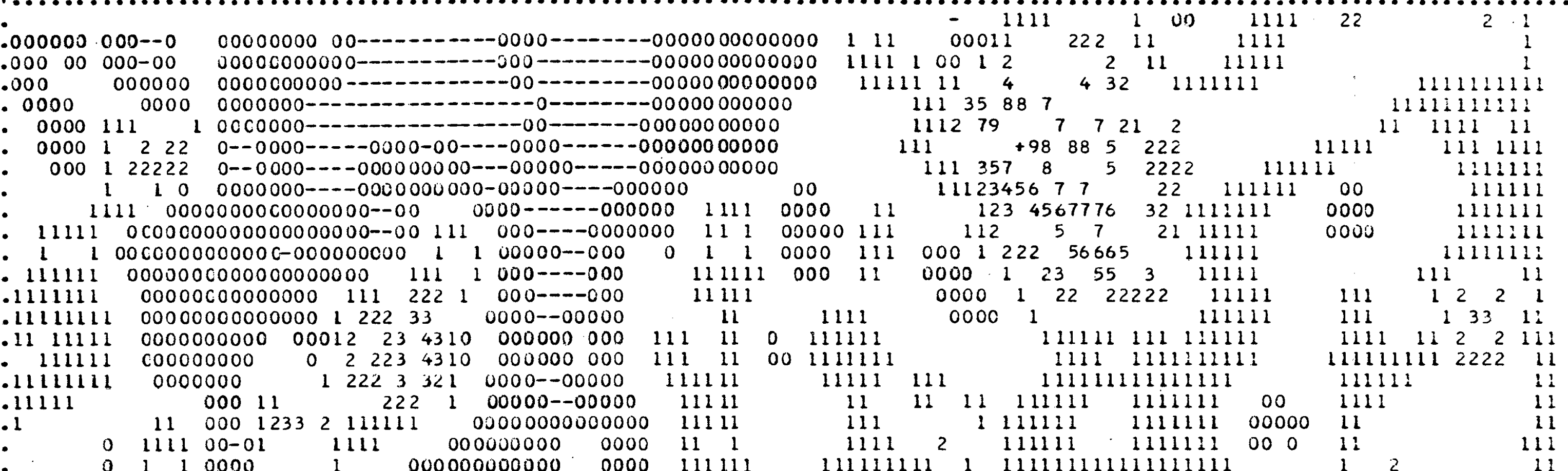

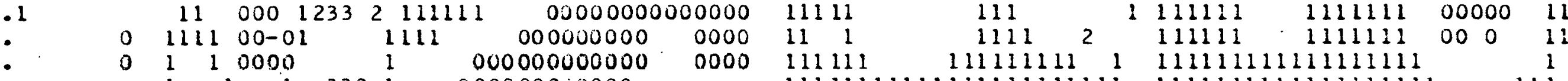

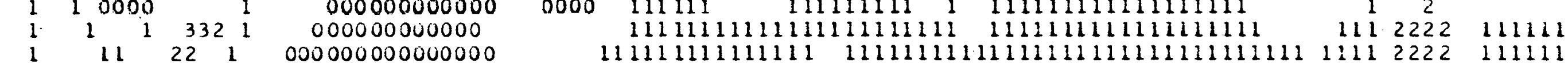

$0 \quad 112222100000000000000-00$ 1111111111111 1111 111111111111111111 1111 111 11122211111111

$12221000000000000000-00$ 111111111111 1111 111111111111111111111111 111111

- 1122211000000000000000000011111111111 111. 1111111111111:111111111111111

$\begin{array}{lllllllll}111122 & 0000000000 & 11111111111111111111 & 111111111111 & 1111\end{array}$

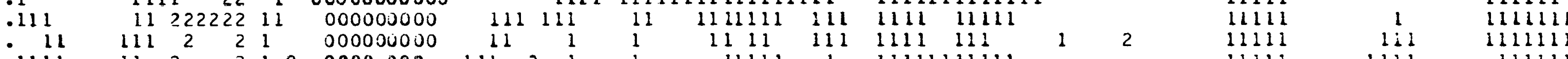

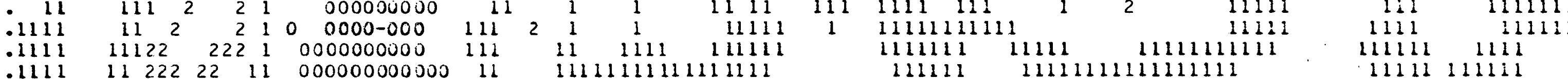

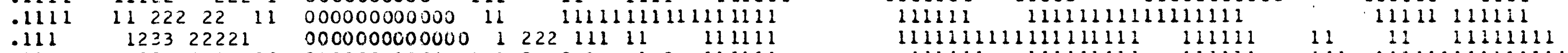



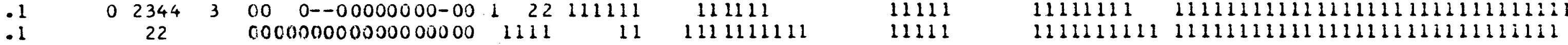

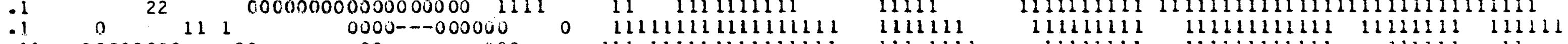

111 1111111111111111111 1111111 111111

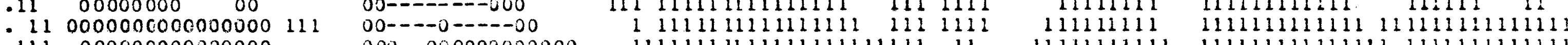

$.11100000000000000 \quad 000-000000000000$ 111111111111111111111 11 1111111111 1111111111111111111111111

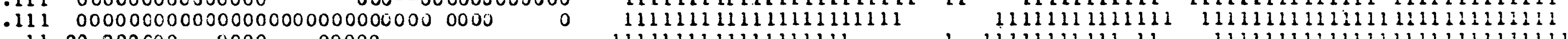

- $1100000000 \quad 0000--00000 \quad 111111111111111111 \quad 1111111111111$ 111111111111111111111111111

$.2100 \quad 000 \quad 0000-0-00 \quad 11111 \quad 11111111111111111 \quad 11111111111111 \quad 1111111111111111111111$

$.3200 \quad 000110000---00000011111$ 111111111 1111111 111111111 1111111111111111111111111

$.20000-0000$ 1i1112 111111111 1111111111100011111111111111111111111111111111211112

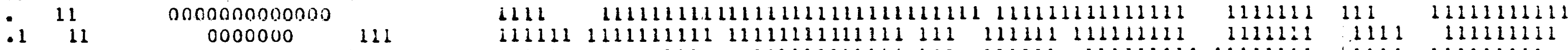

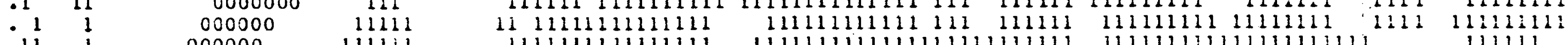

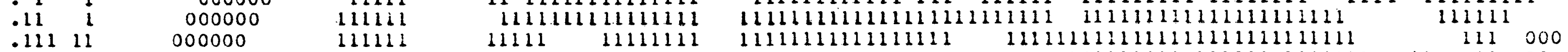

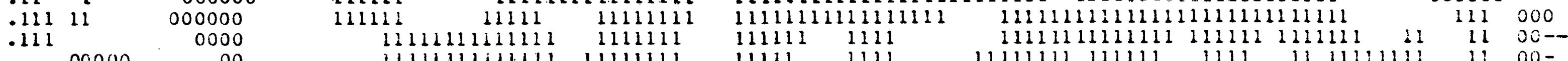

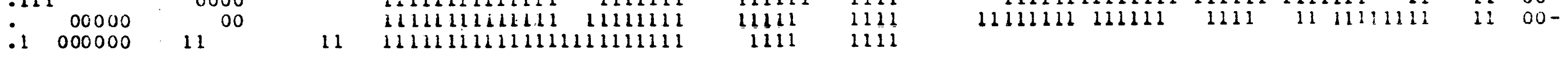


LEGEND TO URN POT RATIO MAP

\begin{tabular}{ccc} 
& LOWER LIMIT & IIPPER LIMIT \\
\hline & & 1.8 \\
1 & 1.8 & 2.3 \\
2 & 2.3 & 2.8 \\
3 & 2.8 & 3.2 \\
4 & 3.2 & 3.7 \\
5 & 3.7 & 4.1 \\
6 & 4.1 & 4.6 \\
7 & 4.6 & 5.1 \\
8 & 5.1 & 6.0 \\
9 & 5.5 & 6.5 \\
+ & 6.0 & \\
\hline
\end{tabular}




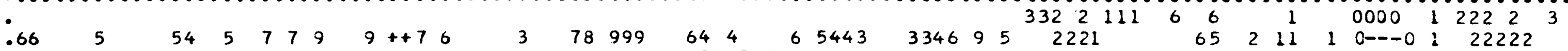

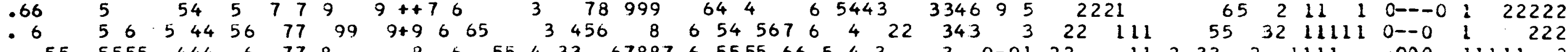

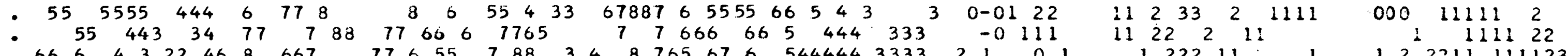

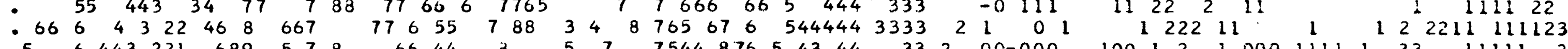

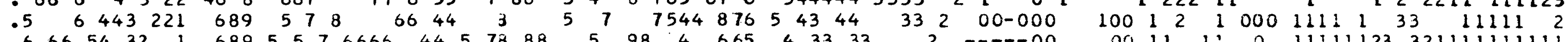

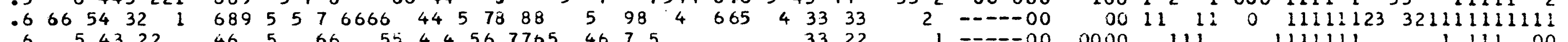

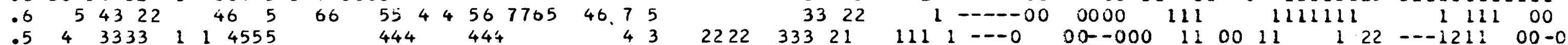

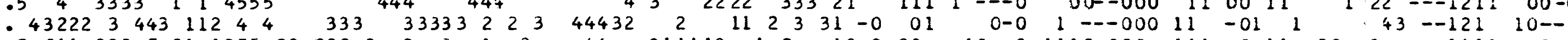
$\begin{array}{llllllllllllllllllllllllllll}.5 & 211 & 223 & 5 & 31 & 1355 & 33 & 322 & 3 & 3 & 3 & 1 & 2 & 44 & 011110 & 1 & 2 & 10-0 & 00 & 10--0 & 1110-000 & 111 & 0 & 11 & 22 & 3 & 1111 & 00\end{array}$ $\begin{array}{lllllllllllllllllllll}3 & 32112 & 3210 & 3 & 222 & 21 & 1 & 1112 & 1 & 11 & 1 & 21000 & 11 & 0-0 & 11 & 11111 & 11 & 2222 & 111 & 1111\end{array}$

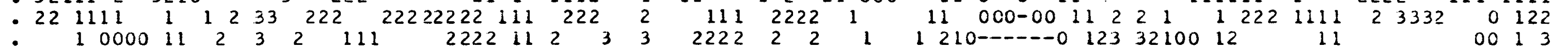

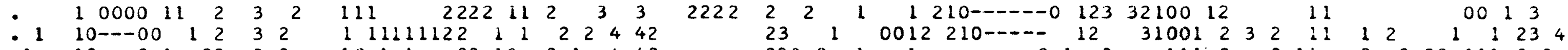

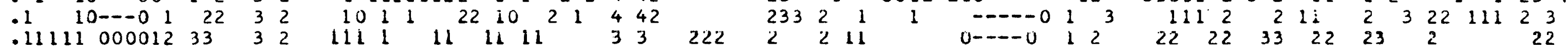

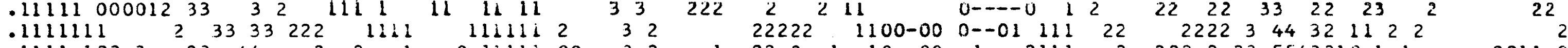

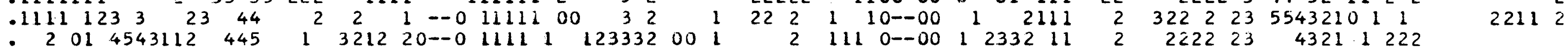

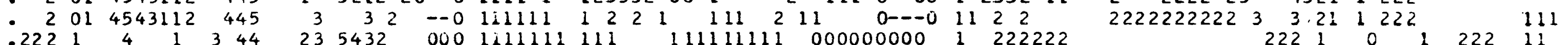

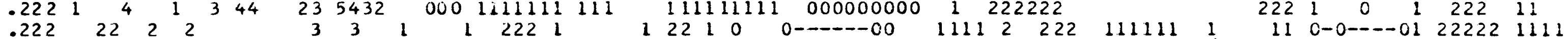

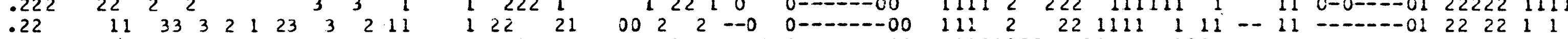

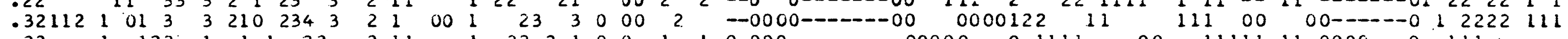

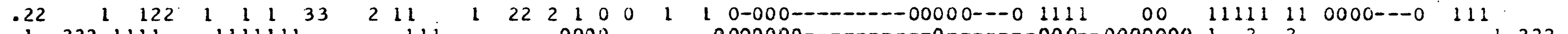

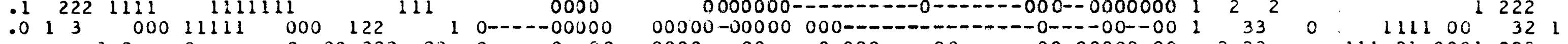

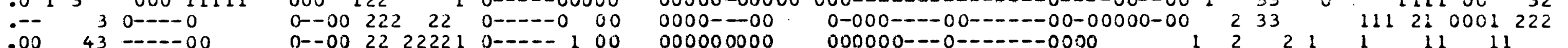

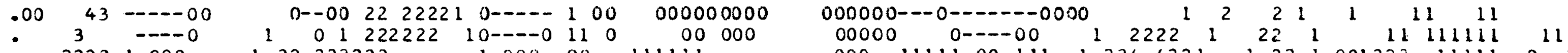

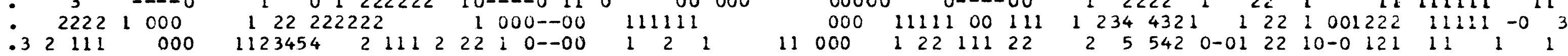

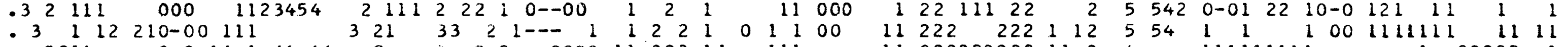

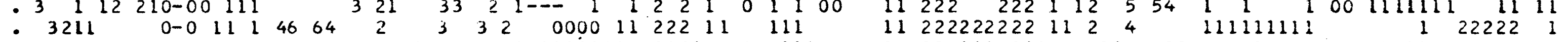

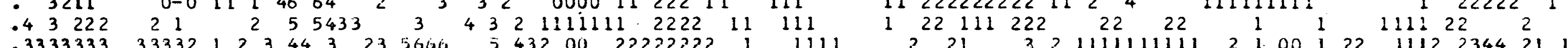

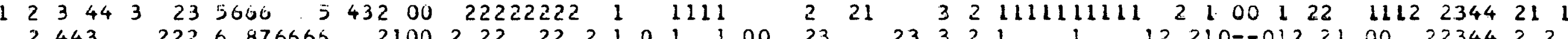

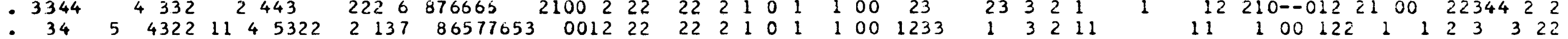

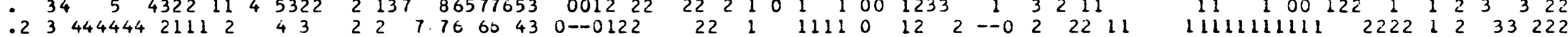

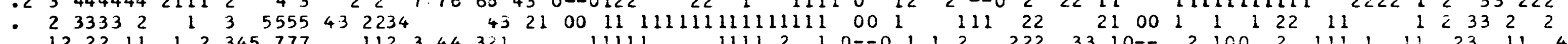

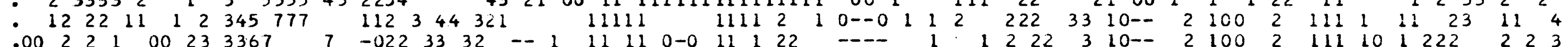

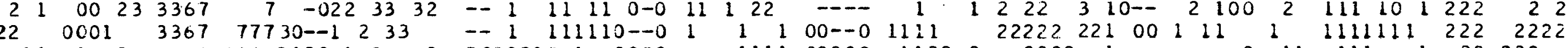

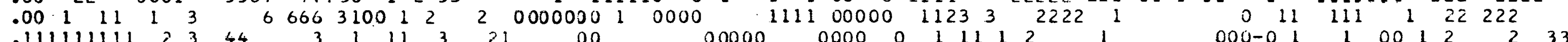

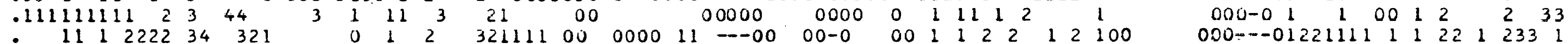

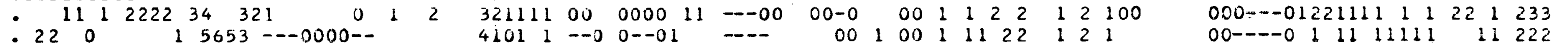

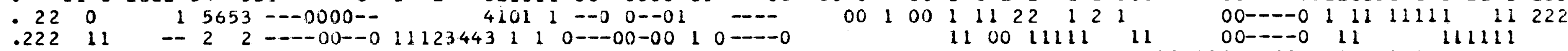

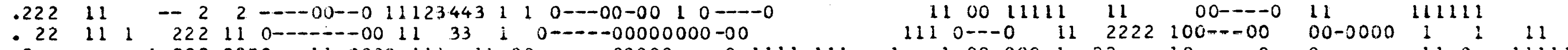

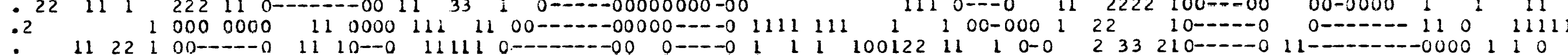

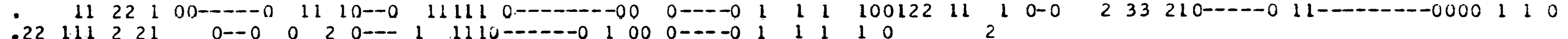


LEGEND TO URN THOR RAT IO MAP

\begin{tabular}{ccc}
\hline CONTOUR VALUE & LOWER LIMIT & 0.1 \\
\hline & & UPPER LIMIT \\
1 & 0.1 & 0.2 \\
2 & 0.2 & 0.2 \\
3 & 0.2 & 0.2 \\
4 & 0.2 & 0.3 \\
5 & 0.3 & 0.3 \\
6 & 0.3 & 0.4 \\
7 & 0.4 & 0.4 \\
8 & 0.4 & 0.4 \\
9 & 0.4 & 0.5 \\
4 & 0.5 & 0.5
\end{tabular}




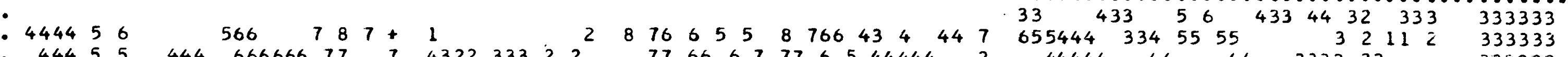

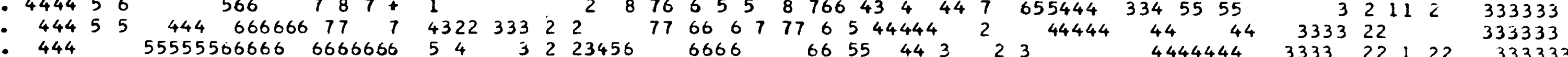

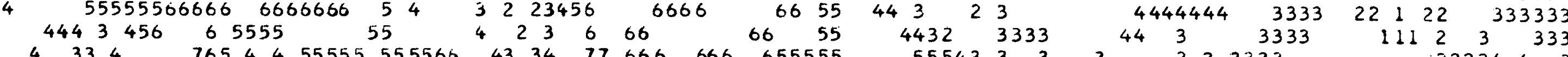

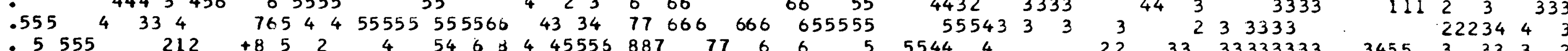

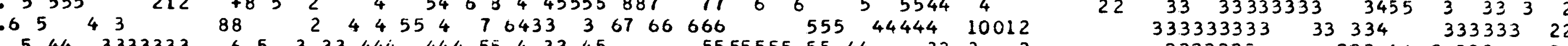
$\begin{array}{llllllllllllllllllll}5 & 44 & 3333333 & 6 & 5 & 3 & 33 & 444 & 444 & 55 & 4 & 33 & 45 & 5555555 & 55 & 44 & 33 & 2 & 2 & 3333333\end{array}$

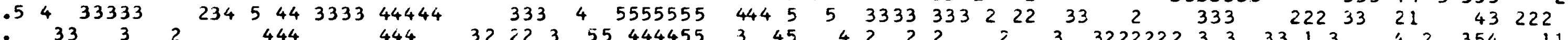

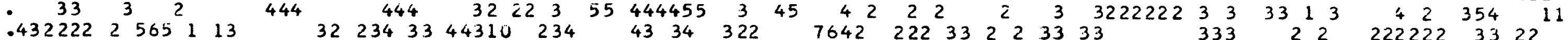

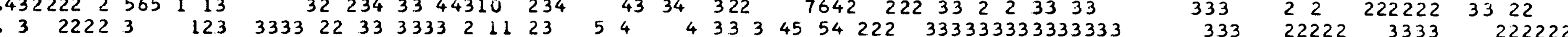

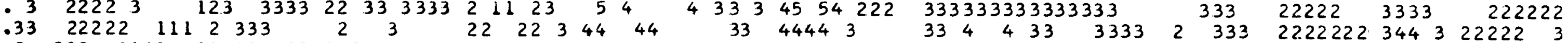

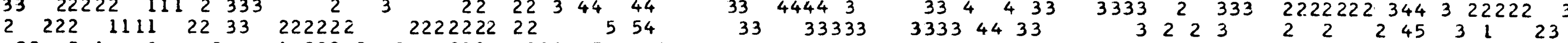

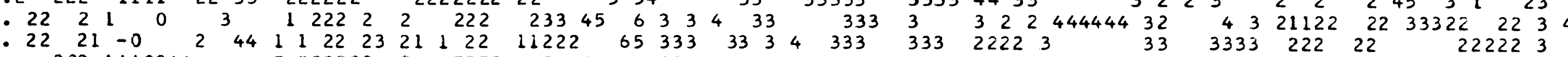

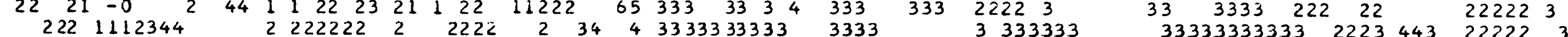

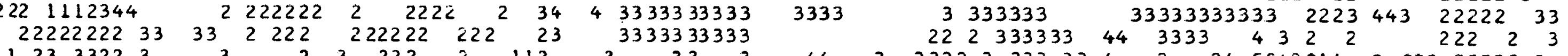

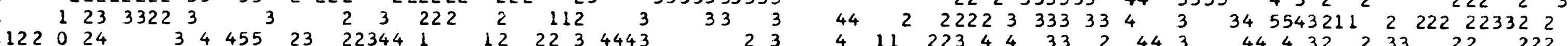

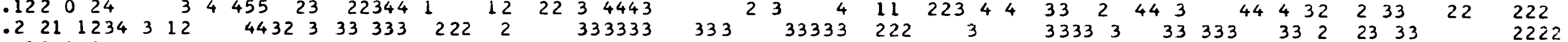

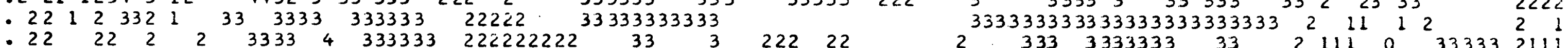

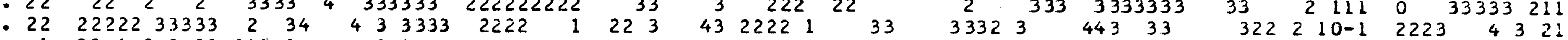

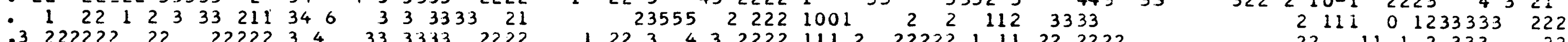

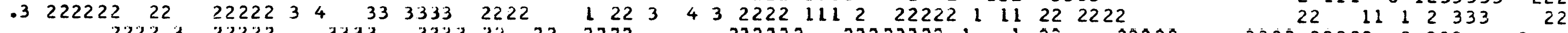

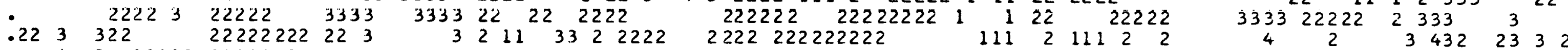

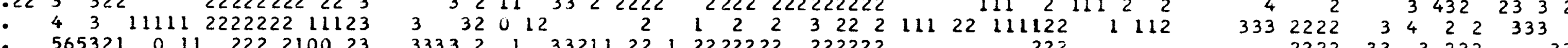

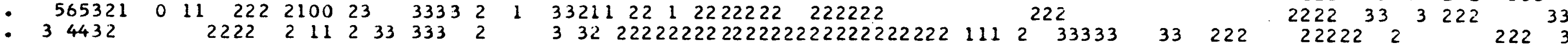

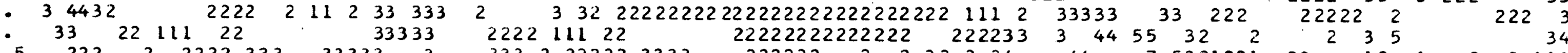

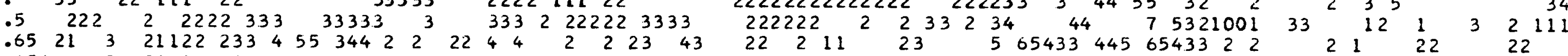

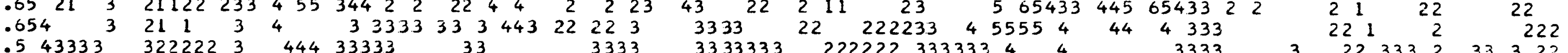
$\begin{array}{lllllllllllll}3333 & 444 & 33 & 444 & 33 & 4443332 & 33322\end{array}$

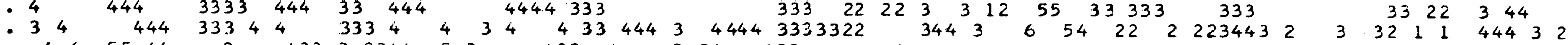

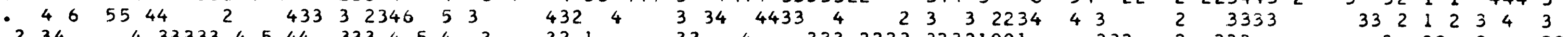

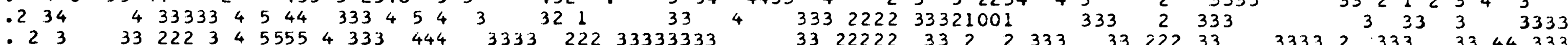

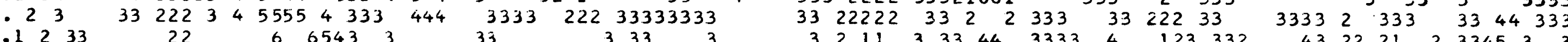

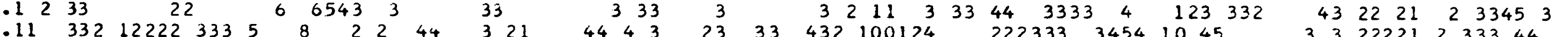

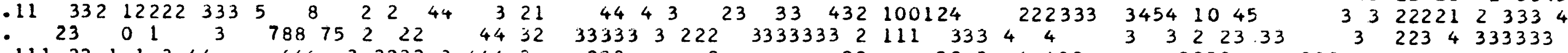

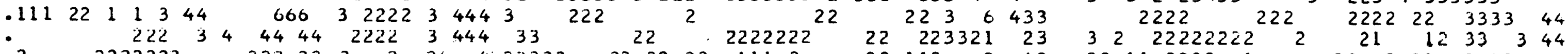

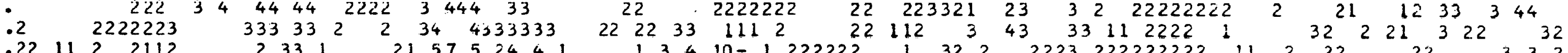

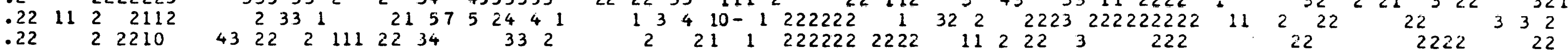

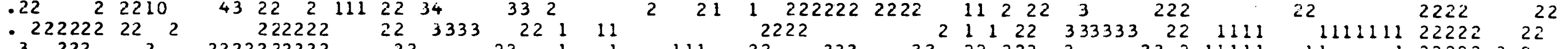

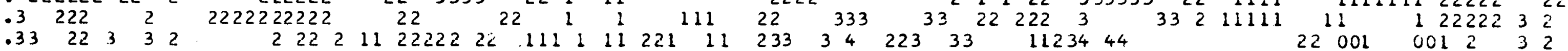

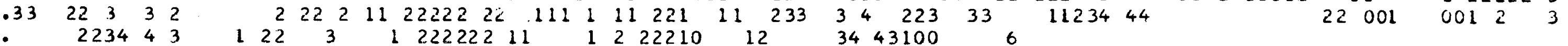


LEGEIND TO THOR POT RAT 10 MAP

\begin{tabular}{ccc}
\hline CONTOUR VALUE & LONER LIMIT & UPPER LIMIT \\
\hline & & 3.5 \\
1 & 3.5 & 4.0 \\
2 & 4.0 & 4.5 \\
3 & 4.5 & 5.0 \\
4 & 5.0 & 5.5 \\
5 & 5.5 & 6.0 \\
6 & 6.0 & 7.0 \\
7 & 6.5 & 7.5 \\
8 & 7.0 & 8.0 \\
9 & 7.5 & 8.5 \\
4 & 8.0 & \\
\hline
\end{tabular}


$\begin{array}{lllllllllllllllllllllll}3333 & 222 & 4 & 6 & 2 & 22 & 2 & 2 & 5 & 444 & 55 & 4\end{array}$

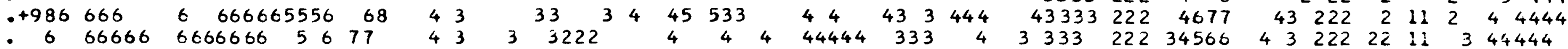

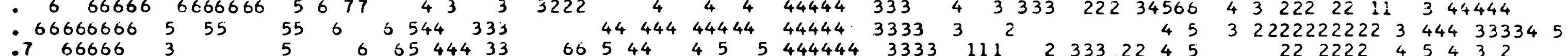

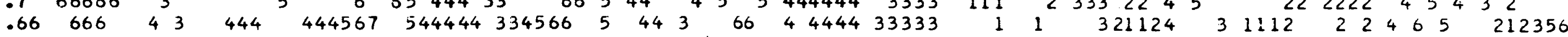

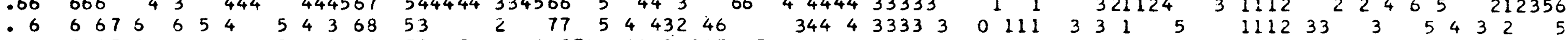

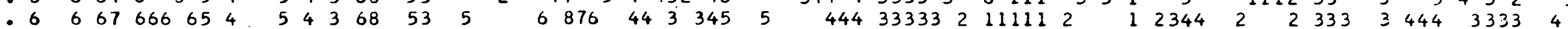

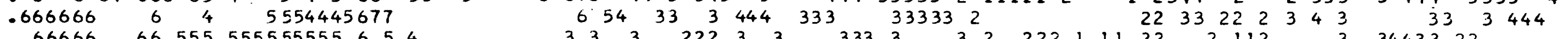

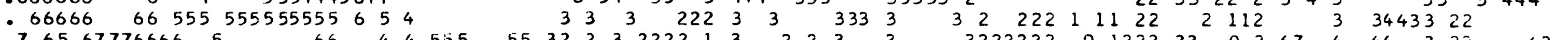

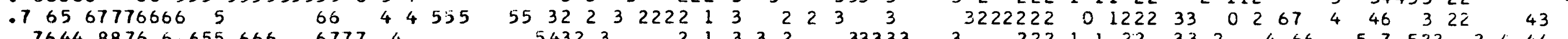

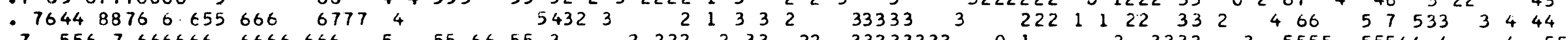
$\begin{array}{lllllllllllllllllllllllllll}.7 & 556 & 7666566 & 6666 & 666 & 5 & 55 & 66 & 55 & 3 & 2 & 222 & 2 & 33 & 22 & 33333333 & 0 & 1 & 1 & 2 & 3333 & 3 & 5555 & 55544 & 4 & 4 & 55\end{array}$

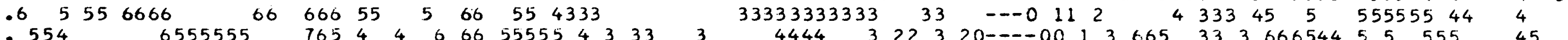

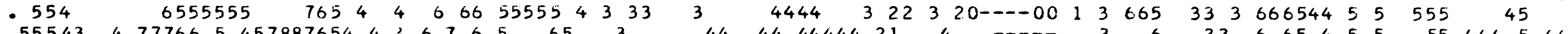

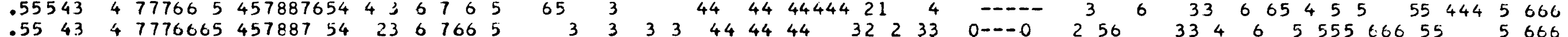

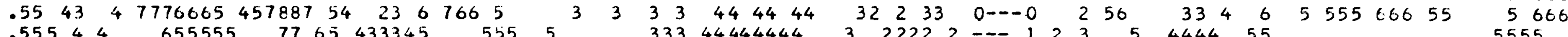

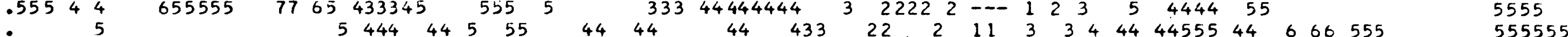

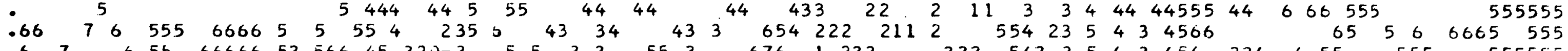

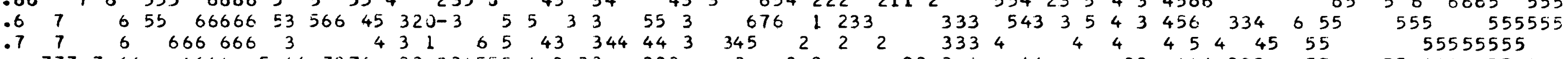

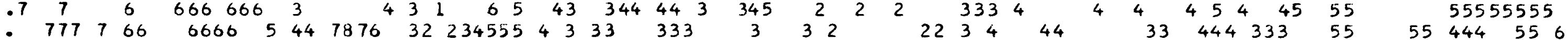

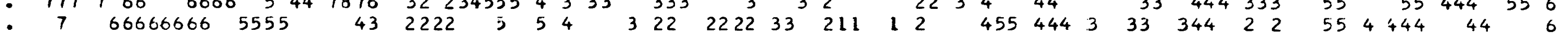

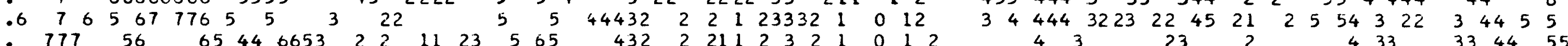

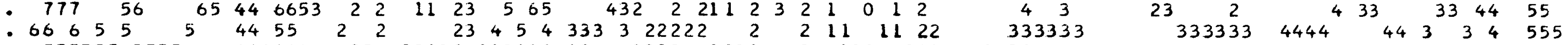

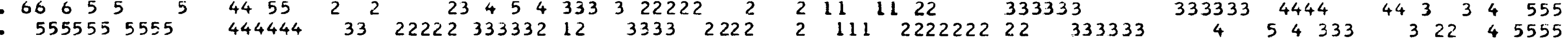

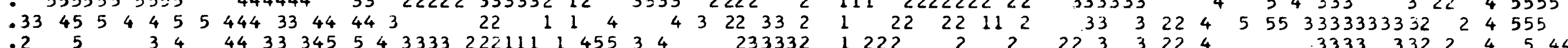

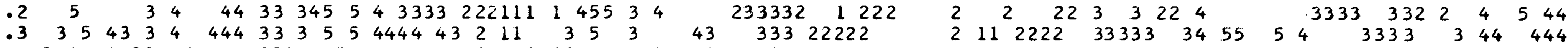

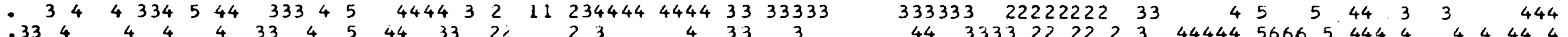

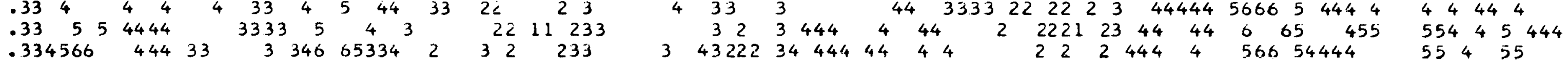

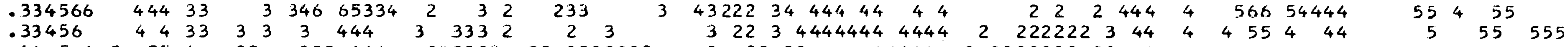

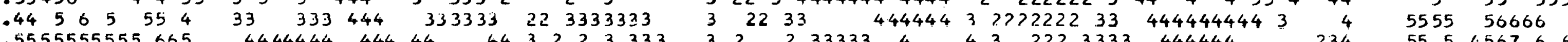

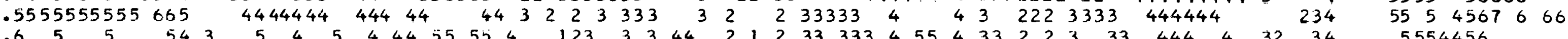

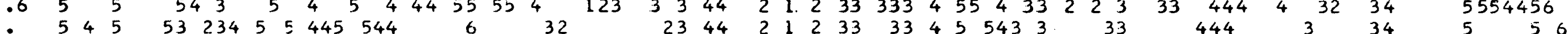

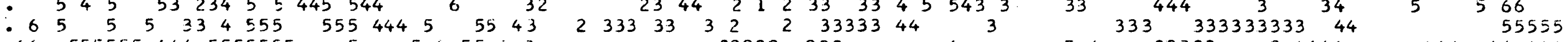
$\begin{array}{llllllllllll}.66 & 5555554445555555 & 5 & 565543 & 22222 & 333 & 4 & 53 & 33333 & 34444 & 444 & 44444\end{array}$

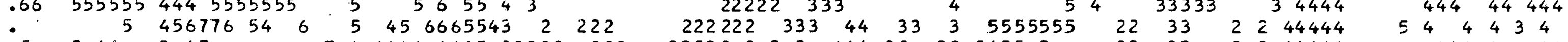

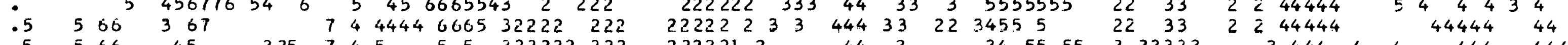

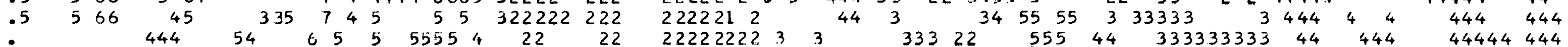
$\begin{array}{lllllllllllllllll}06666 & 55444 & 4333 & 4 & 5555555443 & 2222222 & 22 & 33 & 33 & 3 & 444 & 444 & 5 & 4 & 333333333445555555 & 44444 & 44\end{array}$

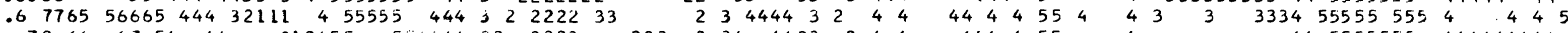

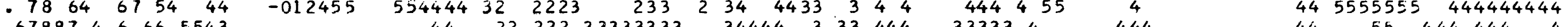
$.6788746665543 \quad 44 \quad 2222233333333 \quad 34444 \quad 333444 \quad 333334 \quad 444$

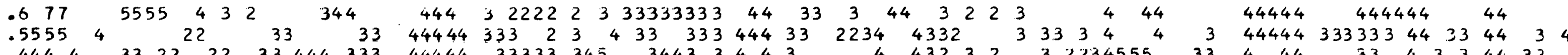

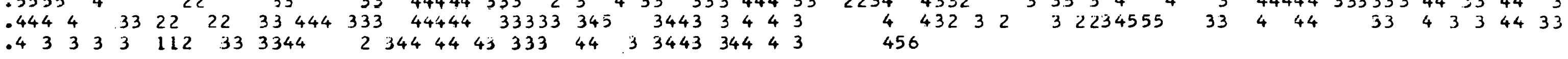


not the same. The radioactive levels are appreciably high only on Traverse 520 and Traverse 540; the intervals of increased gamma radiation on Traverse 500 and Traverse 560 are included because of their apparent continuity to the north and south, respectively. Magnetic deviation over this igneous complex is slight, but this is consistent with a felsic body. On Traverse 560 (fiducials 4840-4880 and 5030-5090) and Traverse 580 (fiducials 1600-1700) strong gamma radiation in all three spectral windows is observed. These intervals are probably attributable to a northeastsouthwest striking rock unit rather than being the expressions of discrete radioactive deposits, because they are present on adjacent traverses to the northeast and southwest in diminished expression and interisity. In addition, the intervals of gamma radiation are coincident with a strong, complex magnetic anomaly. The zone of increased radioactivity corresponds in location to a zone in the undifferentiated pre-Cambrian-Paleozoic metamorphic basement $(\mathrm{Ppc})$. Its probable source is a metamorphic fácles in this complex possibly mineralized by intrusion and pyrometasomatic replacement. This belt of more radioactive rock in the metamorphic basement is apparently the source of the incipient dual peaking in the metamorphic basement histogram distributions previously discussed.

On Traverse 640 (fïducials 770-910) and Tie line 5080 (fiducials 4990-5040), in the west-central part of the Iditarod quadrangle another zone of relatively intense gamma radiation, accompanied by a strong magnetic excursion, is observed. This feature is also located in the outcrop area of the undifferentiated pre-Cambrian-Paleozoic metamorphic basement $(\mathrm{Ppc})$. Furthermore, it is a southwestward continuation of the trend observed on Traverse 560 and Traverse 580. By inference, the source of this anomalous zone is likely to be the same as that on Traverse 560 and Traverse 580 to the northeast. 


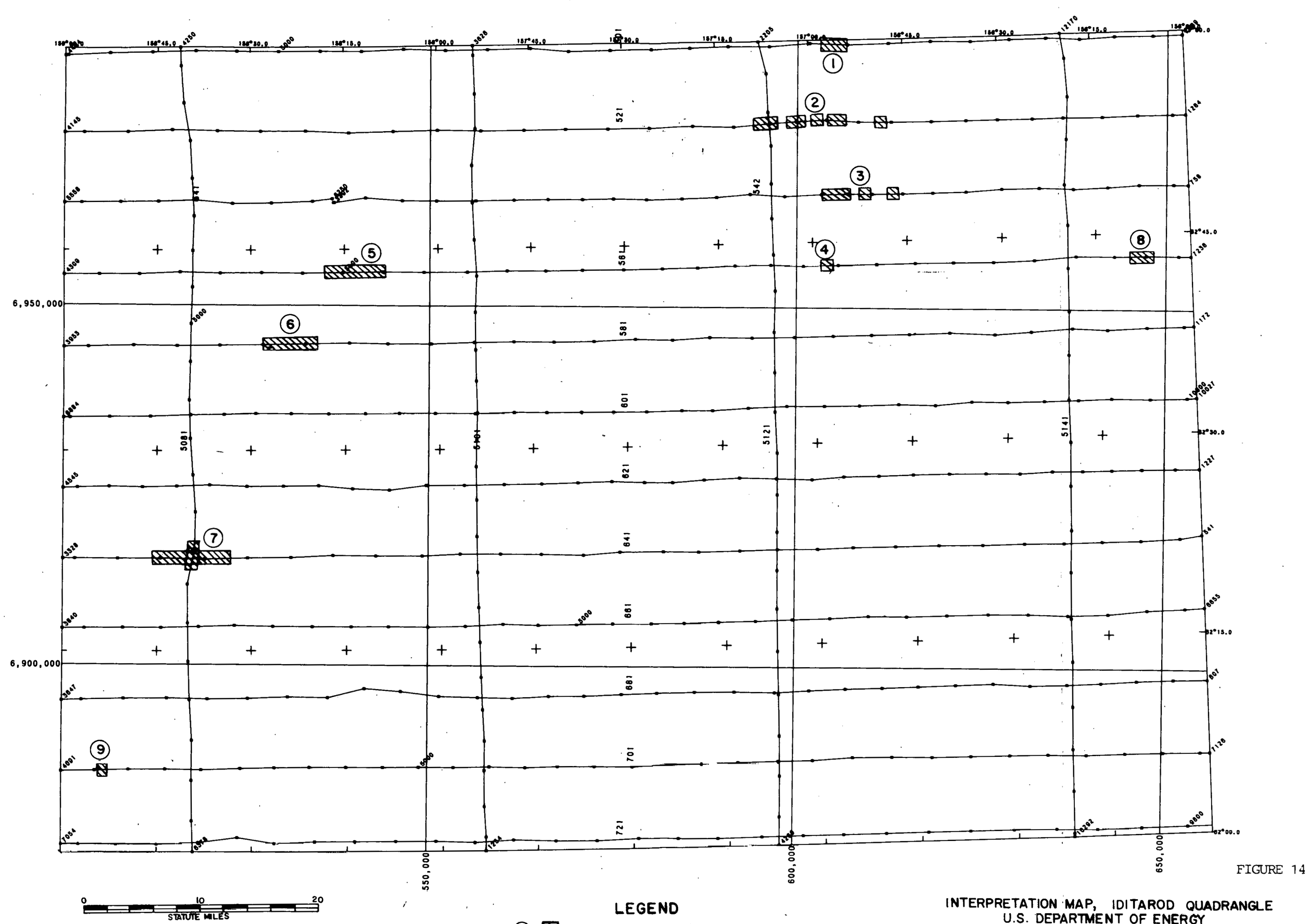

g. Aero service $_{\text {a }}$

LEGEND
(3) URANIUM, THORIÜM ANOMALY No.3

RETATION MAP, IDITAROD QUAD
U.S. DEPARTMENT OF ENERGY 
A strong, isolated gamma radiation peak is observed in the northeastern part of the quadrangle, on Traverse 560 (fiducials 7040-7080). It also corresponds to an exposure of Cretaceous-Tertiary granite and/or quartz diorite, and it is anomalous on all three spectral channels.

In the southwestern corner of the Iditarod quadrangle, an abrupt, intense radiometric anomaly is present on Traverse 700 (fiducials 41004130). The feature is manifested on all three spectral windows. It corresponds in location to an isolated peak called Mosquito Mountain. Examination of the profiles indicate that appropriate correction for terrain clearance was made and the radiometric anomaly is valid. The region is mapped as Kuskokwim siltstone, shale and sandstone (Kk).

Several other ganma radiation anomalies are present on the Iditarod quadrangle that were considered to be spurious and were dismissed because of apparent undercorrection for atmospheric radon or signal amplification due to normalizing low count-rate data over a large altitude variance. 
Aero Service, 1979: Report on calibration tests with the rotary wing garma-ray spectrometer system. Aug. 1979.

Bennison, A.: Geological Highway Map of the State of Alaska, Amer. Assoc. Petroleum Geol. , Map No. 8.

Brinck, J. W., 1974: The geochemical distribution of uranium as a primary criterion for the formation of ore deposits. in Formation of Ore Deposits. IAEA, Vienna 1974.

Churkin Jr., Michael, 1973: Paleozoic and Precambrian rocks of Alaska and their role in its structural evolution. U.S.G.S. Professional Paper 740.

Dutro, J. T. and Payne, T. G., 1954: Geologic map of Alaska. U.S.G.S. Department of the Interior. 1:2,500,000.

Eakin, Henry M., 1914: The Iditarod-Ruby region, Alaska. U.S.G.S. Bulletin 578.

Eakin, Henry M., 1916: 'the Yukon-koyrkuk reglun, Aldskd. U.3.G.3. Bulletin 631 .

Eakins, G. R. et alii, 1977: Investigation of Alaska's uranium potential. State of Alaska Division of Geological and Geochemical Surveys. Alaska Open File Report AOF-109.

Eberlein, G. D., 1977: Preliminary geologic map of Central Alaska. U.S.G.S. Open File Report 77-168-A.

ESCA-TECH Corporation, Geology of the Iditarod Quadrangle, Alaska.

Finch, W., et al: United States Mineral Resources: Nuclear Fuels, U.S. Geological Survey Prof. Paper 820, 1973.

Martin, G. C., 1926: The Mesozoic stratigraphy of Alaska. U.S.G.S. Bulletin 776 .

Plertie Jr., J. B. and Harrington, G. L., 1924: The Rihy-Knskokwim region, Alaska. U.S.G.S. Bulletin 754 .

Mertie Ir., T. B., 1933: Mineral deposits of the Ruby-Kuskokwim region, Alaska. U.S.G.S. Bulletin 864-C /1936/.

Mertie Jr., J. B., 1934: The Kaiyuh Hills, Alaska. U.S.G.S. Bulletin 868-D /1937/.

Mertie Jr., J. B., 1937: The Yukon-Tanana region, Alaska. U.S.G.S. Bulletin 872 .

Miller, D. J. et alii, 1959: Geology of possible petroleum provinces in Alaska. U.S.G.S. Bulletin 1094. 
Moore, J. G. et alii, 1963: The quartz diorite line in North America. in Geological Survey Research 1962. U.S.G.S. Professional Paper 450-E.

Orth, Donald J., 1967: Dictionary of Alaska palce names. U.S.G.S. Professional Paper 567 (Reprinted 1971).

Patton, W.: Petroleum Possibilities of Yukon-Koyukuk Province, Alaska, Future Petroleum Provinces of the United States, Amer. Assoc. Petroleum Geol., Memoir 15, 1971.

Patton Jr., W. W., 1973: Reconnaissance geology of the northern YukonKoyukuk province, Alaska. U.S.G.S. Prefessional Paper 774-A.

Patton Jr., W. W., 1976: Pre-Ordovician unconformity in Central Alaska. in Alaska, Accomplishments during 1976, K. M. Blean editor. U.S.G.S. Circular 751-B.

Payne, Thomas G., 1954: Mesozoic and Cenozoic tectonic elements of Alaska. U.S.G.S. Miscellaneous Geologic Investigations Map I-84.

Reed, B. and Lanphere, M.: Age and Chemistry of Mesozoic and Tertiary Plutonic Rocks in South-Central Alaska, Geol: Soc. Amer. bul., Vol. 80 No. 1, January 1969 ,. p. 23-44.

Richter, D. and Matson, N.: Quaternary Faulting in the Eastern Alaska Range, Geol. Soc. Amer. bul., Vol. 82 No. 6, June 1971, p. 1529-1540.

Till, R.: Statistical Methods for the Earth Scientist, Halsted Press, John Wiley \& Sons, New York, 1974.

Wright, F.: The Encyclopedia of World Regional Geology, Part 1; Western Hemisphere, Section on Alaska, Halsted Press, John Wiley \& Sons, New York, 1975.

Zietz, D. et alii, 1960: Regional aeromagnetic surveys of possible petroleum provinces in Alaska. in Geological Survey Research 1960. U.S.G.S. Professional Paper $400-\bar{B}$. 
Aero Symbol Map Symbol

\begin{tabular}{|c|c|c|}
\hline QA, QAW & Qal & $\begin{array}{l}\text { : Surficial deposits, undifferentiated } \\
\text { Quaternary }\end{array}$ \\
\hline QM & Qmt & $\begin{array}{l}\text { : Mine tailings } \\
\text { Quaternary }\end{array}$ \\
\hline \multirow[t]{3}{*}{ KK } & $\mathrm{Kk}$ & $\begin{array}{l}\text { : Kuskokwim Group } \\
\text { Upper Cretaceous }\end{array}$ \\
\hline & Kkh & $\begin{array}{l}\text { : Kuskokwim Group hornfels } \\
\text { Upper Cretaceous }\end{array}$ \\
\hline & $\mathrm{Pz}$ & $\begin{array}{l}\text { : Metasedimentary rocks } \\
\text { Paleozoic }\end{array}$ \\
\hline PC & PC & $\begin{array}{l}\text { : Chert, limestone and sandstone } \\
\text { Mississippian? }\end{array}$ \\
\hline PP & $\mathrm{Ppc}$ & $\begin{array}{l}\text { : Undifferentiated metamorphic rock } \\
\text { PreCambrian/Upper Paleozoic }\end{array}$ \\
\hline QT & Qtv & $\begin{array}{c}\text { : Basaltic and andesitic flows } \\
\text { Tertiary/Quaternary }\end{array}$ \\
\hline TR & $\operatorname{Tr}$ & $\begin{array}{c}\text { : Albite rhyolite } \\
\text { Tertiary }\end{array}$ \\
\hline TM & $\operatorname{Tmi}$ & $\begin{array}{l}\text { : Pyroxene diorite, gabbro, pyroxenite, diabase } \\
\text { Tertiary }\end{array}$ \\
\hline TQ & TKqd & $\begin{array}{l}\text { : Granite to quartz diorite } \\
\text { Cretaceous to Tertiary }\end{array}$ \\
\hline \multirow[t]{2}{*}{ TK } & Tkv & $\begin{array}{c}\text { : Dacite, rhyolite, basalt sills and dikes } \\
\text { Cretaceous to Tertiary }\end{array}$ \\
\hline & $\mathrm{Kb}$ & $\begin{array}{l}\text { : Basaltic agglomerate flow breccia } \\
\text { Upper Cretaceous }\end{array}$ \\
\hline KBB，KA & Kba & $\begin{array}{l}\text { : Basalt to andesite flows, minor gabbro } \\
\text { Upper Cretaceous }\end{array}$ \\
\hline $\mathrm{KM}$ & $\mathrm{Km}$ & $\begin{array}{l}\text { : Monzonite, monzodiorite and tonalite, } \\
\text { local quartz monzonite and granodiorite } \\
\text { Upper Cretaceous }\end{array}$ \\
\hline $\mathrm{MZ}$ & $\mathrm{MzV}$ & $\begin{array}{l}\text { : Basalt flows underlain by sedimentary breccia } \\
\text { Paleozoic and Mesozoic }\end{array}$ \\
\hline MP & $\mathrm{MzPz}$ & $\begin{array}{l}\text { : Siltstone, chert, tuff and pillow flows } \\
\text { Paleozoic and Mesozoic }\end{array}$ \\
\hline & & \\
\hline
\end{tabular}




$$
\frac{\text { A P P E N D I X B }}{\text { List of Geologic Units by Anomaly }}
$$


List of Geologic Units by Anomaly

Uranium, Thorium Anomalies

\begin{tabular}{|c|c|c|c|c|}
\hline Anomaly & Formation & Location & Fiducials & Brief Description \\
\hline 1. & $\mathrm{Km}$ & Trav. 500 & $6340-6400$ & $\begin{array}{l}\text { Moderate increase in } U \text { and } \\
\text { Th windows }\end{array}$ \\
\hline 2. & $\mathrm{Km}$ & Trav. 520 & $2860-3280$ & $\begin{array}{l}\text { Strong increase in } U \text { and } \\
\text { Th windows }\end{array}$ \\
\hline 3. & $\mathrm{Km}$ & Trav. 540 & $7600-7820$ & $\begin{array}{l}\text { Strong increase in } \mathrm{U} \text { and } \\
\text { Th windows }\end{array}$ \\
\hline 4. & TKqd & Trav. 560 & $6260-6290$ & $\begin{array}{l}\text { Moderate increase in } U \text { and } \\
\text { Th windows }\end{array}$ \\
\hline 5. & $\mathrm{Pp} \varepsilon$ & Trav. 560 & $\begin{array}{l}4840-4880 \\
5030-5090\end{array}$ & $\begin{array}{l}\text { Strong increase in } U \text {, Th } \\
\text { and } \mathrm{K} \text { windows, magnetic } \\
\text { anomaly }\end{array}$ \\
\hline 6. & $\mathrm{Pp} 6$ & Trav. 580 & $1600-1700$ & $\begin{array}{l}\text { Strong increase in } U, \text { Th } \\
\text { and } K \text { windows, magnetic } \\
\text { anomaly }\end{array}$ \\
\hline 7. & Pps & $\begin{array}{ll}\text { Trav. } & 640 \\
\text { T. L. } & 5080\end{array}$ & $\begin{array}{c}770-910 \\
4990-5040\end{array}$ & $\begin{array}{l}\text { Strong increase in } U \text {, Th } \\
\text { and } K \text { windows, magnetic } \\
\text { anomaly }\end{array}$ \\
\hline 8. & TKqd & Trav. 560 & $7040-7080$ & $\begin{array}{l}\text { Strong, isolated } U, T h \text { and } \\
K \text { peak with small abrupt } \\
\text { magnetic anomaly }\end{array}$ \\
\hline 9. & Kk & Irav. $\% 00$ & $4100-4130$ & $\begin{array}{l}\text { Strong, isolated } U, T \text { Th and } \\
K \text { peak. }\end{array}$ \\
\hline
\end{tabular}




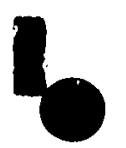

A P PE N D IX

C

List of Anomalies by Geologic Unit 


\section{List of Anomalies by Geologic Unit}

\begin{tabular}{lrrr} 
Formation & Number of Samples & Number of Uranium, Thorium Anomalies \\
\cline { 2 - 3 } TKqd & 179 & 2 \\
Km & 255 & 3 (subdivided into 7 zones) \\
Kk & 23,604 & 1 \\
Pps & 3,942 & 3
\end{tabular}


A P P E N D X D

Mean Radiometric Values by Geologic Unit 
mean value by geologic map undt
ICITARUD
QUAD

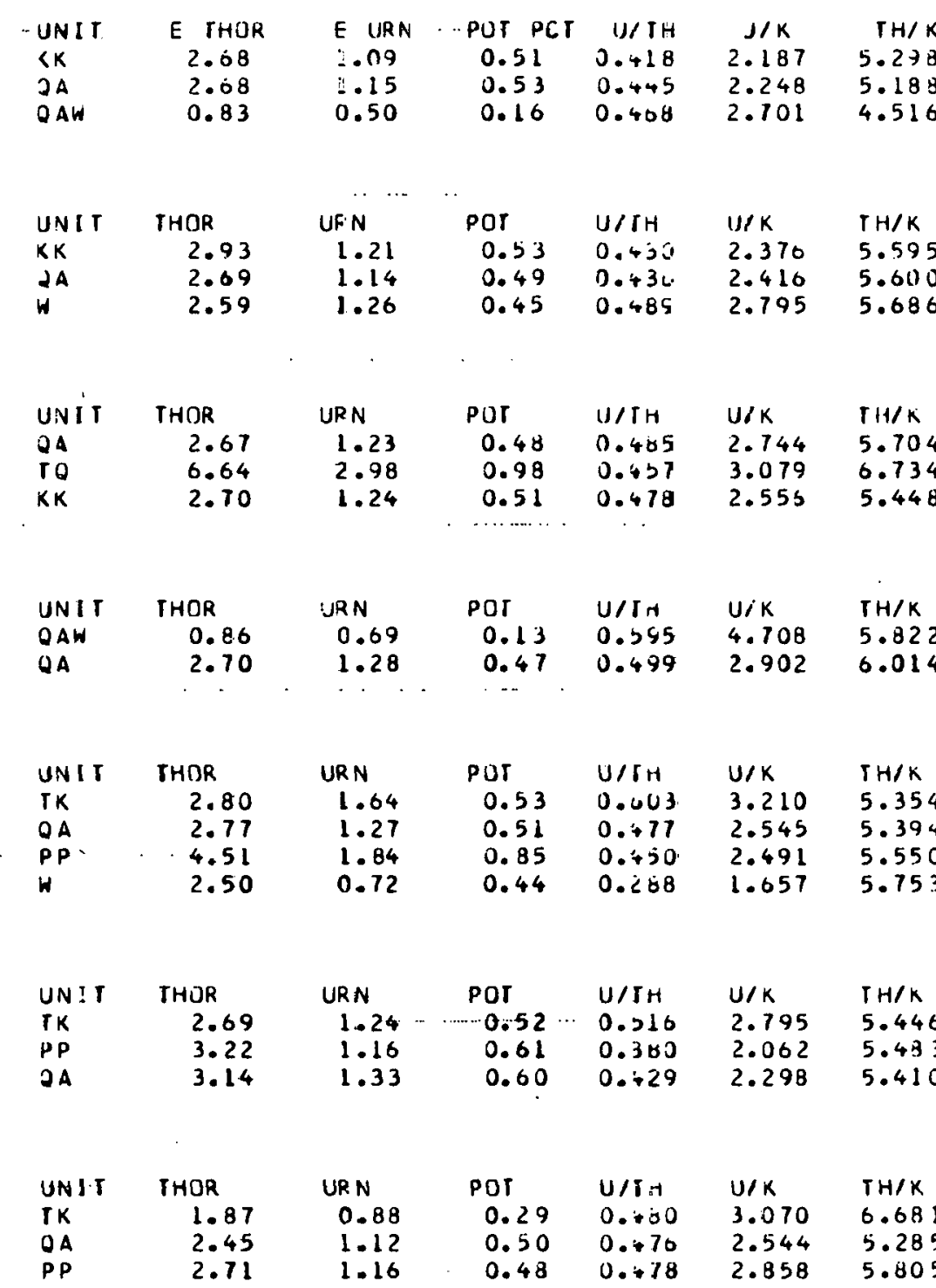

LINE 720

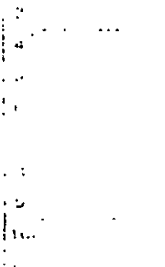

$k$
8
8

LINE

$\begin{array}{lr}\text { UNIT } & \text { E IHOR } \\ \text { MZ } & 1.82 \\ \text { TK } & 2.40 \\ \text { W } & 2.96\end{array}$
E URN
0.99
0.37
$i .17$

PGT PCT U/TH.

$\begin{array}{ll}0.41 & 0.558 \\ 0.51 & 0.156\end{array}$

$\begin{array}{cc}U / K-\cdots H / K \\ 2.619 & 4.716 \\ 0.764 & 4.717 \\ 1.776 & 4.460\end{array}$

$$
700
$$

$\begin{array}{ll}\text { UNIT } & \text { THOR } \\ \text { OAH } & 1.02\end{array}$

1. 17

0.67

0.398

INE $\quad 680$

\begin{tabular}{cccccccc} 
& UNIT & THOR & URN & POT & U/TH & U/K & TH/K \\
& OAW & 0.72 & 0.79 & 0.10 & 1.080 & 6.971 & 5.333 \\
& ML & 1.32 & 0.70 & 0.21 & 0.543 & 3.314 & 6.392 \\
& IR & 2.59 & 1.15 & 0.72 & 0.448 & 1.608 & 3.579 \\
\hline & & & & & &
\end{tabular}

LINE $\quad 640$

$\begin{array}{lcccccc}\text { UNIT } & \text { THOR } & \text { URN } & \text { POT } & \text { U/TH } & \text { U/K } & \text { TH/K } \\ \text { KK } & 2.60 & 1.28 & 0.49 & 0.519 & 2.819 & 5.504 \\ W & 1.38 & 0.82 & 0.35 & 0.610 & 2.386 & 3.996 \\ & & & . & \cdots & 1.36 & \end{array}$

$\begin{array}{lcccccc}\text { UNIT } & \text { THOR } & \text { URN } & \text { POT } & \text { U/TH } & \text { U/K } & \text { TH/K } \\ \text { KK } & 2.93 & 1.36 & 0.55 & 0.480 & 2.683 & 5.475 \\ \text { QAH } & 1.17 & 0.84 & 0.27 & 0.673 & 3.231 & 4.226 \\ \text { TO } & 6.24 & 2.18 & 1.58 & -0.413 & -1.574 & -1.57 .895\end{array}$

LINE $\quad 620$

\begin{tabular}{|c|c|c|c|c|c|c|c|}
\hline & $\begin{array}{l}\text { UNIT } \\
\text { KK } \\
\text { QAW } \\
W\end{array}$ & $\begin{array}{l}\text { THOR } \\
3.21 \\
1.13 \\
2.08\end{array}$ & $\begin{array}{l}\text { URN } \\
.1 .30 \ldots \\
0.61 \\
0.83\end{array}$ & $\begin{array}{l}\text { POJ } \\
-0.66- \\
0.22 \\
0.37\end{array}$ & $\begin{array}{l}\text { U/ TH } \\
0.417 \\
0.545 \\
0.397\end{array}$ & $\begin{array}{l}U / K \\
2.093 \\
2.798 \\
2.216\end{array}$ & $\begin{array}{l}T H / K \\
5.029 \\
5.315 \\
5.642\end{array}$ \\
\hline \multirow[t]{2}{*}{ LINE } & 600 & & & & & & \\
\hline & $\begin{array}{l}\text { UN IT } \\
\text { KK } \\
\text { OAH } \\
\text { TO }\end{array}$ & $\begin{array}{l}\text { THOR } \\
2.92 \\
1.13 \\
2.80\end{array}$ & $\begin{array}{l}\text { URN } \\
1.29 \\
0.37 \\
1.38\end{array}$ & $\begin{array}{l}\text { PQT } \\
0.01 \\
0.17 \\
0.68\end{array}$ & $\begin{array}{l}U / 7 H \\
0.460 \\
0.277 \\
0.501\end{array}$ & $\begin{array}{r}U / K \\
2.296 \\
1.999 \\
2.228\end{array}$ & $\begin{array}{l}\text { THAK } \\
5.058 \\
6.109 \\
4.383\end{array}$ \\
\hline
\end{tabular}


mean valje gy geulcgic map unit

$$
\text { ICITAKUD QUAD }
$$

$\begin{array}{lclll} & & & & \\ \text { UNIT } & \text { E THOR } & \text { FURN } & \text { POT PCT } & \text { UT TH } \\ \text { YP } & 2.64 & 0.84 & 0.43 & 0.546 \\ \text { 2A } & 2.23 & 0.97 & 0.39 & 0.448 \\ \text { PP } & 2.77 & 1.27 & 0.50 & 0.211\end{array}$

$\begin{array}{ll}J / K & \\ 2.338 & 6.41 K \\ 2.622 & 5.965 \\ 2.778 & 5.850\end{array}$

$\begin{array}{lccclll}\text { UNIT } & \text { THOR } & \text { URN } & \text { POT } & \text { LITH } & \text { U/K } & \text { TH/K } \\ \text { MP } & 3.21 & 1.34 & 0.58 & 0.455 & 2.397 & 5.555 \\ \text { PA } & 2.56 & 1.19 & 0.43 & 6.77 U & 2.849 & 6.126 \\ \text { PP } & 3.46 & 1.34 & 0.56 & 0.402 & 2.503 & 6.335 \\ \text { UAW } & 1.06 & 0.50 & 0.17 & 0.762 & 2.925 & 6.082\end{array}$

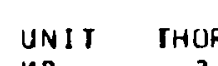

$\begin{array}{lr}\text { UNIT } & \text { THOR } \\ \text { YP } & 3.23 \\ \text { OA } & 3.09 \\ \text { PP } & 1.83 \\ \text { SM } & 11.79\end{array}$

\begin{tabular}{|c|c|c|c|c|c|c|}
\hline $\begin{array}{l}\text { UNIT } \\
\text { TK } \\
\text { PP } \\
\text { OA } \\
\text { OAW }\end{array}$ & $\begin{array}{l}\text { IHOR } \\
2.55 \\
2.19 \\
4.82 \\
1.05\end{array}$ & $\begin{array}{l}\text { URN } \\
-1.62 \\
1.19 \\
2.38 \\
0.80\end{array}$ & $\begin{array}{l}F 08 \\
0.41 \\
0.35 \\
0.93 \\
0.16\end{array}$ & $\begin{array}{l}J / 1 H \\
0.598 \\
1.016 \\
0.237 \\
0.800\end{array}$ & $\begin{array}{l}U / K \\
4.244 \\
4.052 \\
3.033 \\
4.954\end{array}$ & $\begin{array}{l}J H / K \\
6.165 \\
6.050 \\
5.778 \\
6.244\end{array}$ \\
\hline $\begin{array}{l}\text { UN IT } \\
\partial T \\
\text { JA } \\
\text { 2AW } \\
\text { H }\end{array}$ & $\begin{array}{l}\text { THOR } \\
1.09 \\
2.66 \\
0.97 \\
0.63\end{array}$ & $\begin{array}{l}\text { URN } \\
0.64 \\
1.45 \\
0.76 \\
0.51\end{array}$ & $\begin{array}{l}\text { PUT } \\
0.12 \\
0.48 \\
0.14 \\
0.19\end{array}$ & $\begin{array}{l}\text { U/TH } \\
0.028 \\
0.580 \\
0.700 \\
0.558\end{array}$ & $\begin{array}{l}U / K \\
4.833 \\
3.534 \\
5.147 \\
5.149\end{array}$ & $\begin{array}{l}T H / K \\
7.168 \\
5.869 \\
5.898 \\
4.859\end{array}$ \\
\hline $\begin{array}{l}\text { JNI I } \\
\angle K \\
\text { YL } \\
\text { OAW }\end{array}$ & $\begin{array}{l}\text { THOR } \\
1.90 \\
2.04 \\
1.29\end{array}$ & $\begin{array}{l}\text { URN } \\
0.94 \\
0.84 \\
0.62\end{array}$ & $\begin{array}{l}\text { POI } \\
0.30 \\
0.41 \\
0.21\end{array}$ & $\begin{array}{l}U / 1 H \\
0.497 \\
0.416 \\
0.478\end{array}$ & $\begin{array}{l}U / K \\
2.837 \\
2.324 \\
2.999\end{array}$ & $\begin{array}{l}T-1 / K \\
5.041 \\
4.952 \\
6.069\end{array}$ \\
\hline
\end{tabular}

$\begin{array}{lccclll}\text { UNIT } & \text { THOR } & \text { URN } & \text { POI } & \text { J/JH } & \text { UIK } & \text { TH/K } \\ \text { KK } & 2.08 & 0.91 & L .68 & 0.431 & 1.707 & 4.522 \\ \text { OA } & 2.04 & 0.92 & 0.45 & 0.664 & 2.34 J & 4.616\end{array}$

2

580

LINE 580

LINE

$\begin{array}{lr}\text { UNIT } & \text { THOR } \\ \text { QAW } & 1.07\end{array}$

$\begin{array}{ll}K K & 2.76 \\ K B G & 5.71\end{array}$

E URN POT PCT

1.29
1.87

0.140 .577

0.481

0.373

$\begin{array}{lr}U / K & 1 H / K \\ 4.116 & 7.043 \\ 2.687 & 5.683 \\ 1.839 & 5.051\end{array}$

560

$\begin{array}{lcc}\text { UNIT } & \text { THOR } & \text { URN } \\ \text { KK } & 2.78 & 1.28 \\ \text { KBB } & 2.52 & 1.19 \\ \text { TQ } & 5.41 & 2.06 \\ \text { PC } & 2.92 & 1.42\end{array}$

U/TT U/K TH/K

$\begin{array}{llll}0.52 & 0.498 & 2.688 & 5.472 \\ 0.73 & 0.471 & 1.709 & 3.569\end{array}$

$0.73 \quad 0.471 \quad 1.709 \cdot 3.569$

$\begin{array}{llll}1.24 & 0.440 & 1.991 & 4.571 \\ 0.46 & 0.546 & 3.527 & 6.746\end{array}$

LINE $\quad 540$

\begin{tabular}{|c|c|c|c|c|c|c|}
\hline $\begin{array}{l}\text { UN IT } \\
\text { UAW } \\
\text { KK } \\
\text { KA }\end{array}$ & $\begin{array}{r}T-10 R \\
1.12 \\
2.58 \\
10.69\end{array}$ & $\begin{array}{l}\text { URN } \\
0.64 \\
1.17 \\
5.06\end{array}$ & $\begin{array}{l}\text { POT } \\
0.17 \\
0.57 \\
2.73\end{array}$ & $\begin{array}{c}\text { U/T1 } \\
0.544 \\
0.474 \\
-0.481\end{array}$ & $\begin{array}{l}U / K \\
3.612 \\
2.236 \\
1.914\end{array}$ & $\begin{array}{l}\text { TH/K } \\
6.414 \\
4.78\end{array}$ \\
\hline
\end{tabular}

LIVE $\quad 520$

KM

UNIT THOR

$\begin{array}{ll}K K & 3.15 \\ \text { IM } & 2.88 \\ K M & 15.08 \\ K A & 14.51\end{array}$

LINE $\quad 500$

URN
1.5
1.83
7.00
6.8

POT U/TH U/K JH/K

$1.59 \cdots \quad 0.69 \cdots 0.529-2.527-4.821$

$\begin{array}{lllll}7.00 & 3.39 & 0.471 & 2.077 & 4.444\end{array}$

$\begin{array}{lllll}6.80 & 3.39 & 0.471 & 2.077 & 4.444 \\ 6.21 & 0.496 & 2.122 & \ldots .4 .355\end{array}$

$\begin{array}{lr}\text { UNIT } & \text { THOK } \\ \text { PP } & 1.19 \\ \text { KK } & 3.27 \\ \text { QM } & 4.30 \\ \text { KM } & 4.40\end{array}$

LINE $\quad 5080$

$\begin{array}{lcc}\text { UNIT } & \text { IHOR } & \text { URN } \\ \text { QA } & 2.41 & 1.03 \\ \text { PP } & 3.80 & 1.35 \\ \text { QT } & 1.21 & 0.67\end{array}$

LINE 5100

$\begin{array}{lr}\text { UNIT } & \text { THOK } \\ \text { PP } & 1.03 \\ \text { QAW } & 0.65\end{array}$

URN

0.56
0.45

POT

$\begin{array}{llll}0.18 & 0.496 & U / K & T H / K \\ 0.162 & 5.792\end{array}$

0.10 
MFAN VALJE BY GEJLOGIC MAP UNIT

$$
\text { IRIIARGO WUAO }
$$

LINE: 5120

$\begin{array}{ll}\text { JNIT } & \text { E THORR } \\ \text { KK } & 2.39 \\ \text { QA } & 2.74\end{array}$

E URN
$n .92$
1.07

$\begin{array}{ll}\text { POT PCI } & \text { U/IH } \\ \text { a. } 51 & 0.0+405\end{array}$

$\begin{array}{ll}\text { a. } 51 & 0.006 \\ 0.67 & 0.404\end{array}$

$U / K$
1.713

1.713
1.693

$\mathrm{r} H / K$
4.863

4.863
4.217

UNI

UNIT E THCR
AW
0.98

$\begin{array}{ll}\text { WAW } & 0.98 \\ \text { KBB } & 2.06\end{array}$

E URN

0.87

POT PC T

$\begin{array}{ll}\text { PC T } & \text { U/TH } \\ 0.16 & 0.728\end{array}$

0.68

0.728
0.475

$U / K$
4.179

4.179
1.378

TH/K

LINE $\quad 5140$

UNIF THOR URA POT U/IH U/K TH/K

KK $\quad 3.25$

$1 \cdot 31$

$0.60 \quad 0.425 \quad 2.342 \quad 5.555$

UNIT THOR

QA

2.86

JRN

1.39

POT ... U/THA U/K …TH/K

$\begin{array}{llll}0.50 \quad 0.516 & 2.980 & 5.845\end{array}$ 
A P P E D I X E

Standard Deviation Table 
FORMAT ION

\begin{tabular}{|c|c|c|c|c|}
\hline DATA & SAMPLES & MEAN & & -3 \\
\hline E THCRIUM & 9110 & 2.33 & LUGNGKMAL & 0.29 \\
\hline E URANIUM & 8825 & 1.23 & NOKMAL & -0.35 \\
\hline POTASSIUM & 9133 & 0.41 & LOGNUKAAL & 0.04 \\
\hline EU/K & 8771 & 2.53 & NORMAL & -0.61 \\
\hline EU/E $H$ & 8624 & 0.45 & NORMAL & -0.06 \\
\hline ETH/K: & 9065 & 5.42 & NORMAL & 1.39 \\
\hline
\end{tabular}

FOKMATION

DATA SAMPLES

E THORIUM

E URANIUM

POTASSIUM

EU/K

EU/ET
ETH/K

\section{AMPLES}

MEAN

$-3$

$\begin{array}{lllr}3026 & 0.63 & \text { NURMAL } & -0.38 \\ 3116 & 0.60 & \text { NORMAL } & -0.36 \\ 3541 & 4.13 & \text { NUKMAL } & -0.11 \\ 2223 & 0.26 & \text { LOGNORMAL } & 0.93 \\ 1563 & 0.59 & \text { NUKMAL } & -0.23 \\ 2462 & 5.85 & \text { NUKMAL } & 0.68\end{array}$

[I]

DATA

E THORIUM

E URANIUM

POTAJSIUM

EU/K

ETHIK

$\begin{array}{rll}\text { SAMPLES } & \text { MEAN } & \\ 17 & 4.14 & \text { NURMAL } \\ 17 & 1.67 & \text { LUGNOKMAL } \\ 17 & 0.63 & \text { LGGNUKMAL } \\ 17 & 1.70 & \text { NOKMAL } \\ 17 & 1.42 & \text { NORMAL } \\ 17 & 4.13 & \text { NORMAL } \\ 17 & 4.13 & \end{array}$

FORMATION

$-3$

3.10
1.16
0.51
1.10
0.29
2.23

FORMAT I CN

\begin{tabular}{|c|c|c|c|c|}
\hline СATA & SAMPLES & $M \subset \bar{A} \bar{N}$ & & -3 \\
\hline E THJKIUM & 23100 & 2.04 & NUKMAL & 0.18 \\
\hline$\ddot{E}$ URANIUH & 23604 & 1.14 & NUKMAL & -0.26 \\
\hline PUTASSIUM & 24129 & u.be & NOKMAL & 0.02 \\
\hline EU/K & 23555 & $\angle<0$ & NUKMAL & -0.42 \\
\hline EUIETH & 23312 & 0.43 & NCKMAL & -0.06 \\
\hline ETH/K & 24045 & 3.13 & WOKMAL & 1.75 \\
\hline
\end{tabular}

KK

6

$\begin{array}{ll}-< & -1 \\ u .50 & 1.16 \\ u .17 & 0.70 \\ \text { U. U. } & 0.19 \\ \text { U.44 } & 1.49 \\ \text { U.11 } & 0.28 \\ \text { L.73 } & 4.08\end{array}$

WAW

$-2$

U.03

$-0.04$

-v.va

1.42

2.41

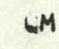

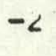

2.45

1. 31

0.00

1. 36

4.34
4.86

$-<$

1. UO

u.

v.lo

4.48

U. iv

<.

\section{$-1$}

0.44
0.28

0.28

0.05

2.15

0.32

4.13

$-1$

3.79

1.48

0.71

1. 54

0.38

3.50

$-1$

1.82

0.67

0.35

1.38

0.27

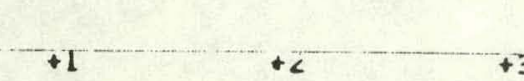

4.69
1.75
0.90
3.58
0.63
6.76

$\begin{array}{ll}9.43 & 18.97 \\ 2.28 & 2.80 \\ 1.47 & 4.33 \\ 4.03 & 5.67 \\ 0.00 & 0.97 \\ 0.11 & 9.45\end{array}$

$\begin{array}{lll}+1 & +2 & +3 \\ 1.26 & 1.08 & 2.09 \\ 0.92 & 1.24 & 1.56 \\ 0.20 & 0.26 & 0.36 \\ 4.96 & 7.53 & 11.43 \\ 0.87 & 1.14 & 1.41 \\ 7.57 & 9.29 & 11.01\end{array}$

71

4.49
1.88
0.97
1.98
0.46
4.76

$+2$

$+3$

4.84

$2.5<\quad 2.40$

$\begin{array}{ll}1.14 & 1.34 \\ 2.20 & 2.42\end{array}$

$\begin{array}{ll}0.50 & 0.54 \\ 5.40 & 6.03\end{array}$

-.

$\begin{array}{lll}+1 & +2 & +3 \\ 3.46 & 4.24 & 5.11 \\ 1.61 & 2.00 & 2.55 \\ 0.69 & 0.80 & 1.03 \\ 3.18 & 4.08 & 4.98 \\ 0.60 & 0.70 & 0.93 \\ 6.26 & 7.39 & 8.52\end{array}$




\begin{tabular}{|c|c|c|c|}
\hline DATA & SAMPLES & MEAN & \\
\hline E THORIUM & 4190 & 1.18 & LOGNOKMAL \\
\hline E URANIUM & 3942 & U.68 & LOGNOMMAL \\
\hline POTASSIUM & 4223 & 0.19 & + UGNOKMAL \\
\hline$E U / K$ & $38 t 4$ & 1.60 & -OGWOKMAL \\
\hline EU/ETH & 3630 & 0.37 & LOGWJKMAL \\
\hline ETH/K & 4099 & 2.74 & NUKMAL \\
\hline
\end{tabular}

FORMATION PF

$\begin{array}{lll}-3 & -c & -1 \\ 0.11 & u .24 & 0.53 \\ 0.11 & u . c u & 0.36 \\ 0.02 & u .04 & 0.08 \\ 0.36 & u .01 & 1.05 \\ 0.09 & u .1 b & 0.23 \\ 1.15 & <.00 & 4.21\end{array}$

$+1$

2.63

1.27

0.42

$3.1 \mathrm{C}$

7.58

FCRMATION

$$
\begin{array}{r}
-3 \\
-0.38 \\
0.09 \\
-0.16 \\
0.80 \\
0.11 \\
1.27
\end{array}
$$

FORMATION

$\begin{array}{rr}-3 & -< \\ -0.00 & u .25 \\ -0.26 & v .41 \\ -0.14 & -v .05 \\ 1.15 & 1.05 \\ -0.01 & u .16 \\ 2.44 & j .<u\end{array}$

FORMATION

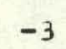

$$
\begin{aligned}
& 1.61 \\
& 0.55 \\
& 0.44 \\
& 0.41 \\
& 0.20 \\
& 2.86
\end{aligned}
$$

FL

$-6$

v.c 7

U. $=6$

velu

1.10
0.17

2.64

$-1$

$+1$

3. 80

1.73

0.63

3.84

0.57

8.37

0.25

4.82

$-1$

0.66

0.28

0.03

2.36

0.37

4.21

$-1$

\section{1. os}

U. $7 c$

U. bs

U. 75

U. 21

2.15

0.88

0.61

1.10

0.34
3.20
$+1$

$+1$

1.32
0.82

0.20

4.05

4.85

0.74
7.28

2. 10

1.22

0.79

1. 78

0.49

3.66
$+<$

$\begin{array}{lr}2.84 & 13.16 \\ 2.30 & 4.39 \\ 2.44 & 2.10 \\ 5.33 & 9.17 \\ 0.91 & 1.43 \\ 3.80 & 10.33\end{array}$

$+2$

$+3$

$\begin{array}{ll}-089 & 50\end{array}$

$2.14 \quad 2.54$

บ. 821.02

$5.69 \quad 8.43$

$\begin{array}{rr}0.80 & 1.31 \\ 14.15 & 11.93\end{array}$

11.93

$\begin{array}{lr}+< & +3 \\ 1.05 & 1.97 \\ 1.09 & 1.36 \\ 0.28 & 0.37 \\ 0.94 & 9.95 \\ 0.93 & 1.12 \\ 4.57 & 12.59\end{array}$

$\leftarrow<$

$+3$

$\begin{array}{ll}4.91 & 3.25 \\ 1.30 & 1.55 \\ 0.01 & 0.96 \\ 2013 & 2.47 \\ \therefore 00 & 0.64 \\ 0.00 & 4.06\end{array}$


IDITAKOL

QUAD
$\operatorname{Tin}$

$\begin{array}{lr}\text { DATA } & \text { SAMPLES } \\ \text { E THOFIUM } & 36 \\ \text { E URANIUM } & 36 \\ \text { POTASSIUM } & 36 \\ \text { EU/K } & 36 \\ \text { EU/ETH } & 36 \\ \text { ETH/K } & 36\end{array}$

FORMATICN

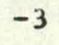

$$
\begin{aligned}
& 0.69 \\
& 0.69 \\
& 0.27 \\
& 0.69 \\
& 0.16 \\
& 2.82
\end{aligned}
$$

\section{FURMATICN}

$-3$

\subsection{9}

0.67

0.10

0.52

0.03

1.01

FORMATION

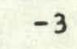

$-0.42$

$-0.55$

0.10

$-0.35$

-0.16
1.60

FLKMATION

$-3$

$-2.35$

-1.23
-0.86

1.00

0.25

2.43

\section{$-2$}

1. 1

i. 44

v. 32

1. 50

U. 32

2.20

Tw

1. $1 v$

U. 87

U. 17

U. 73

U. 10

$<.09$

IK

$-2$

v. 41

v. U1

U. 15

U. 75

0.07

$<.96$

KA

$-2$

C. 20

U. 99

0.37

$1 .<0$

U. 32

C. S)
$+1$

3.40

2.08

0.60

$\begin{array}{ll}2.42 & 4.16 \\ 0.48 & 0.79 \\ 3.76 & 5.01\end{array}$

$\begin{array}{ll}2.42 & 4.16 \\ 0.48 & 0.79 \\ 3.76 & 5.01\end{array}$

$-1$

1.73

1.13

0.29

1.02

0.29

3.16

$-1$

1.37

0.58

0.22

1.85

0.29

4.36

$-1$

6.91

3.20

1.60

1.55

0.39

3.43

$+1$

4. 34

1.89

0.84

2.03

5.32

$+1$

3.15

1. 70

0.45

0.73
7.12

$\begin{array}{ll}+2 & +3 \\ 4.00 & 4.76 \\ 2.45 & 2.78 \\ 0.72 & 0.88 \\ 3.03 & 5.89 \\ 0.94 & 1.10 \\ 5.74 & 6.69\end{array}$

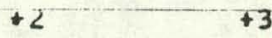

$\begin{array}{ll}0.00 & 10.84 \\ 2.40 & 3.18 \\ 1.49 & 2.43 \\ 2.05 & 4.01 \\ 0.69 & 0.83 \\ 0.34 & 7.47\end{array}$

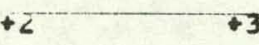

4.06

4.03

2.26

0.64

3. 10

0.95
0.50

4.94

2.82

0.92

6.26

9.89

ETH/K 171

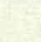

$\begin{array}{rrr}+1 & +2 & +3 \\ 16.17 & 20.00 & 25.43 \\ 7.64 & 9.85 & 12.07 \\ 4.06 & 0.29 & 6.52 \\ 2.10 & 2.36 & 2.65 \\ 0.53 & 0.60 & 0.67 \\ 4.42 & 4.94 & 5.41\end{array}$




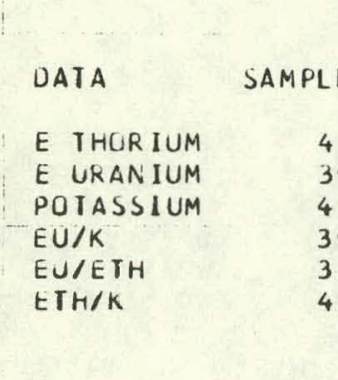

\begin{tabular}{|c|c|c|c|}
\hline DATA & SAMPLES & MEAN & \\
\hline E THCR IUM & 255 & 13.05 & NURMAL \\
\hline E URANIUM & 255 & 0.17 & NGKMAL \\
\hline POTASSIUM & 255 & $3.1<$ & ISUKMAL \\
\hline$E U / K$ & 255 & 1.06 & NUKMMLL \\
\hline EU/ETH & 255 & 0.42 & NUKMAL \\
\hline ETH/K & 255 & 4.32 & TNOKMAL \\
\hline \multicolumn{4}{|l|}{ 出 } \\
\hline DATA & SAMPLES & MLAN & \\
\hline E THOF IUM & $62 t$ & 1.53 & NORMAL \\
\hline E URANIUM & 578 & 0.75 & NUKMAL \\
\hline POTASSIUM & 634 & 0.34 & NOKMAL \\
\hline EU/K & 544 & 1.61 & LUGNOKMAL \\
\hline EU/ETH & 517 & 0.49 & MOKMAL \\
\hline ETH/K & 596 & 2.47 & LUG VUKMAL \\
\hline DATA & SAMPLES & MCAN & \\
\hline E THUR IUM & 282 & 3.61 & NUK MAL \\
\hline E URANIUM & 282 & 1.22 & NUKMAL \\
\hline POTASSIUM & 282 & 0.54 & NUKMAL \\
\hline$E U / K$ & 282 & 1.87 & LLGINORMAL \\
\hline EU/ETH & 282 & 0.41 & NGKIMAL \\
\hline ETH/K & 282 & b.bc & NUKMAL \\
\hline
\end{tabular}

RORMATICN NOD

$\begin{array}{rll}-j & -c & -1 \\ 0.29 & u . j 1 & 0.93 \\ -0.38 & u .1 u & 0.57 \\ 0.13 & u .23 & 0.52 \\ -0.41 & u .21 & 0.83 \\ -0.02 & u .13 & 0.28 \\ 0.97 & 1.30 & 1.90\end{array}$

FORMAT ICN

KM

$-3$

4.57

1.42
1.16

1.10

$$
\begin{aligned}
& 0.22 \\
& 2.61
\end{aligned}
$$

FORMAT ICM

$-2$

7.67

1.04
1.04

1. 35

U. 24

2.10

$N<$

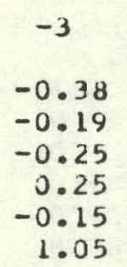

$-2$

u. <o

$v .12$
$-v .160$

$-u . v 6$
$ن .47$

v. ve

FORMATICA

$M P$

$-3$

1.43
0.37

0.25

0.60

0.02

2.70
$-1$

2.49

0.93

0.44

1.28

0.28

$\begin{array}{lll}+1 & +2 & +3 \\ 2.99 & 2.20 & 9.67 \\ 1.52 & 1.00 & 2.48 \\ 0.91 & 1.11 & 1.30 \\ 2.07 & 2.00 & 3.30 \\ 0.59 & 0.74 & 0.90 \\ 3.70 & 2.10 & 7.21\end{array}$

$+1$

10.76

4.58
2.46

2.46

1.60

0.36

3. 75

$-1$

0.90

0.90

0.14

0.87

0.28

2.33

16. 94

7.75
3.77

3. 77

2.11

0.49
4.88

$+<$

$+3$

$\begin{array}{rr}\text { Cu. us } & 23.13 \\ 9.34 & 10.92 \\ 4.42 & 5.07 \\ 2.30 & 2.61 \\ u .50 & 0.62 \\ 0.40 & 6.02\end{array}$

$+1$

$+3$

$\begin{array}{llr}2.17 & 2.81 & 3.44 \\ 1.07 & 1.38 & 1.70 \\ 0.54 & 0.73 & 0.93 \\ 2.98 & 5.52 & 10.23 \\ 0.70 & 0.92 & 1.13 \\ 5.18 & 7.71 & 11.49\end{array}$

5.18

7.71

1.49

+1
3.54
1.50
0.63
2.74
0.54
6.51

$\begin{array}{ll}+2 & +3 \\ 4.01 & 4.60 \\ 1.78 & 2.07 \\ 3.73 & 0.83 \\ +.02 & 5.88 \\ 1.07 & 0.80 \\ 7.40 & 8.41\end{array}$




\begin{tabular}{|llll} 
& SAMPLES & MEAIV & \\
& & & \\
DATA & & & \\
E THOFIUM & 39 & 1.07 & NUKMAL \\
E URANIUM & 62 & $\cup .31$ & NOKMAL \\
POTASSIUM & 49 & 4.27 & NOKMAL \\
EU/K & 34 & 1.70 & LOGNUKMAL \\
EUTETH & 30 & 0.41 & NOKMAL \\
ETH/K & 34 & 4.33 & NUKMAL
\end{tabular}

FORMATICN

$-3$

$-1 . t 1$

$-\frac{1}{2}$

0.58

0.24

$-0.38$

$-0.50$

$-v .14$

-v. 10

$-0.03$

U. 15

U. 12

1.13

0.28

4.06

2. 77

0.98

0.49

2. 55

0.58

5.80

2.00 4.96

$1.30 \quad 1.73$

U. $11 \quad 0.92$

2.035 .75

$0.74 \quad 0.89$

$0.00 \quad 7.53$

思 
A P PENDIX F

Single Record Data Listing 


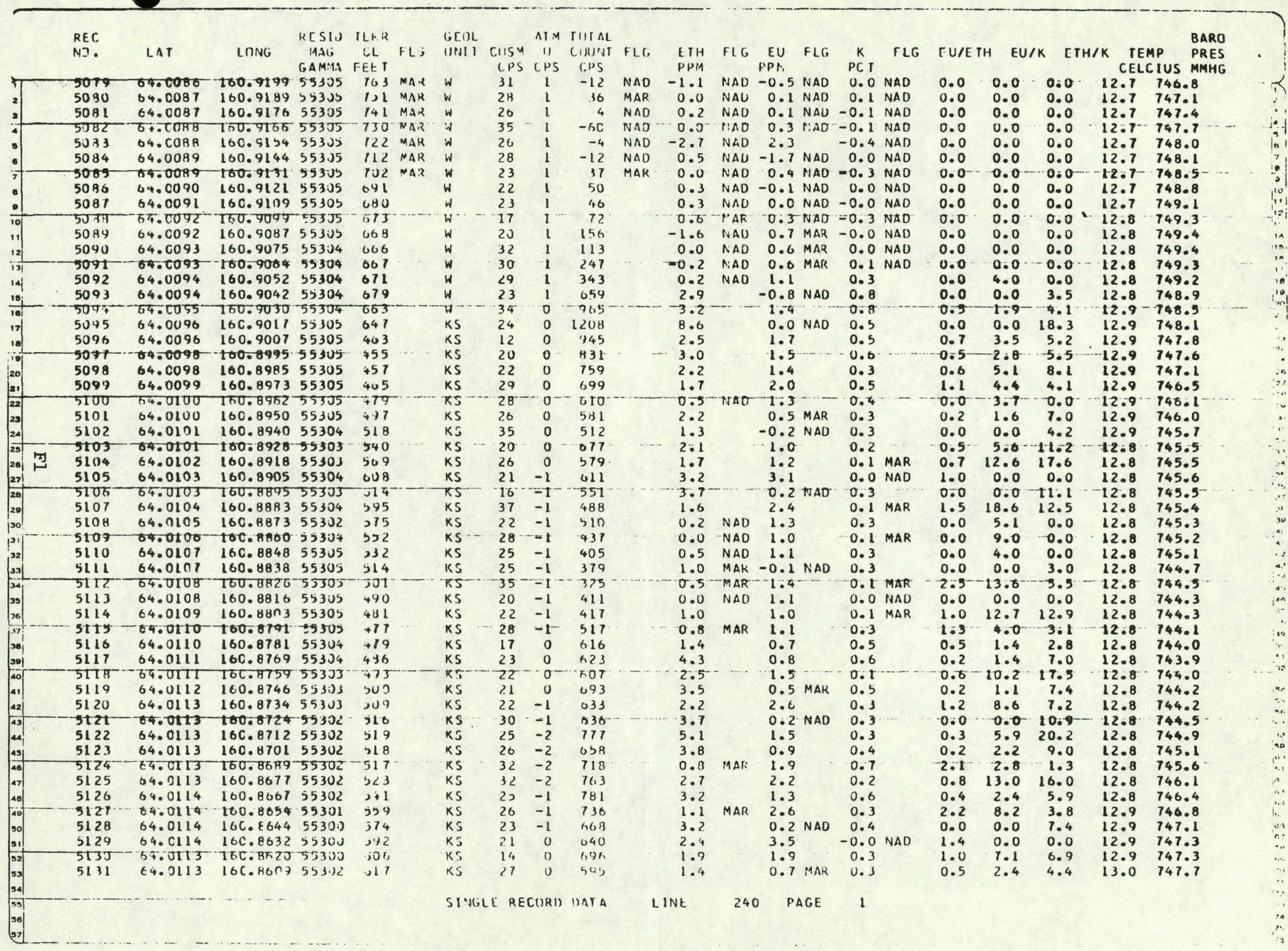


A P P E N D I X G

Average Record Data Listing 
RECORO

RESIO

\begin{tabular}{|c|c|c|c|c|c|}
\hline & $\begin{array}{l}\text { RECORD } \\
\text { NUYBER }\end{array}$ & LATITUDE & LONGI TUDE & $\begin{array}{l}\text { TOTAL } \\
\text { FIELU }\end{array}$ & $\begin{array}{l}\text { GEUL } \\
\text { INI T }\end{array}$ \\
\hline & 5185 & 0007 & 0.8023 & 55293 & s \\
\hline & $\begin{array}{l}3186 \\
5187 \\
5189\end{array}$ & $\begin{array}{r}65.0086 \\
64.0085\end{array}$ & $\begin{array}{l}-160.8012 \\
-160.8002 \\
-160.1992\end{array}$ & $\begin{array}{l}55292 \\
55291 \\
55390\end{array}$ & $\begin{array}{l}k 5 \\
k 5 \\
k 5\end{array}$ \\
\hline & $\begin{array}{l}5188 \\
5189\end{array}$ & $\begin{array}{r}64.0085 \\
64.0084\end{array}$ & $\begin{array}{l}-160.7992 \\
-160.7982\end{array}$ & $\begin{array}{l}55290 \\
55291\end{array}$ & $\begin{array}{l}k 5 \\
k 5\end{array}$ \\
\hline & $\begin{array}{l}5190 \\
5191\end{array}$ & $\begin{array}{l}64.0085 \\
64.0085\end{array}$ & $\begin{array}{l}-160.7971 \\
-160.7961\end{array}$ & $\begin{array}{l}55291 \\
55291\end{array}$ & $\begin{array}{l}\text { N } \\
\text { KS }\end{array}$ \\
\hline & 5192 & 64.0085 & -160.7949 & 55290 & $k 5$ \\
\hline & $\begin{array}{l}5193 \\
5194\end{array}$ & $\begin{array}{l}64.0085 \\
64.0084\end{array}$ & $\begin{array}{l}-160.7939 \\
-160.7928\end{array}$ & $\begin{array}{l}55290 \\
5529 J\end{array}$ & $\begin{array}{l}\text { KS } \\
\text { KS }\end{array}$ \\
\hline & 5195 & 64.0084 & -160.7918 & 35289 & KS \\
\hline & $\begin{array}{l}5196 \\
5197\end{array}$ & $\begin{array}{l}64.0084 \\
64.0085\end{array}$ & $\begin{array}{l}-160.7908 \\
-160.7896\end{array}$ & $\begin{array}{l}55289 \\
55292\end{array}$ & $\begin{array}{l}\text { KS } \\
\text { KS }\end{array}$ \\
\hline & 5199 & 64.0085 & -160.7885 & 55292 & ks \\
\hline ורְ: & 5194 & $\begin{array}{l}n 85 \\
085\end{array}$ & $\begin{array}{l}-160.7875 \\
-160.7865\end{array}$ & $\begin{array}{l}55292 \\
55309\end{array}$ & $\begin{array}{l}\text { kS } \\
\text { KS }\end{array}$ \\
\hline & $\begin{array}{l}5200 \\
5201\end{array}$ & $\begin{array}{l}64.0085 \\
.64 .0085\end{array}$ & $\begin{array}{l}-160.7865 \\
-160.7855\end{array}$ & $\begin{array}{l}35292 \\
35291\end{array}$ & $\begin{array}{l}\mathrm{ks} \\
\mathrm{KS}\end{array}$ \\
\hline & 5202 & 64.0086 & -160.7843 & 55291 & KS \\
\hline & & 64.0086 & -160.7832 & $\begin{array}{l}55290 \\
55200\end{array}$ & kS \\
\hline$=31$ & $3204^{\circ}$ & $\begin{array}{l}64.0086 \\
64.0087\end{array}$ & $\begin{array}{l}-160.7822 \\
-160.7812\end{array}$ & $\begin{array}{l}55292 \\
55292\end{array}$ & $\begin{array}{l}\text { KS } \\
\text { KS }\end{array}$ \\
\hline & 5206 & 64.0087 & -160.1802 & 55291 & KS \\
\hline & $\begin{array}{l}5207- \\
5208\end{array}$ & $\begin{array}{l}\begin{array}{r}64.0088 \\
64.0088\end{array}\end{array}$ & $\begin{array}{l}-160.7789 \\
-160.7779\end{array}$ & $\begin{array}{l}55290 \\
55290\end{array}$ & $\begin{array}{l}\text { KS } \\
\text { KS }\end{array}$ \\
\hline & 5209 & 04.0088 & -160.7769 & 55291 & KS \\
\hline & $5210^{\circ}$ & 64.0088 & -160.7759 & 55291 & K5 \\
\hline$=09$ & 5211 & 64.0089 & -160.1747 & 55291 & KS \\
\hline & 5212 & 64.0089 & -160.7736 & 55290 & KS \\
\hline & 5213 & 64.0089 & -160.7126 & 55289 & KS \\
\hline$\ldots$ & 5214 & 64.0090 & -160.1114 & 55284 & KS \\
\hline & 5213 & 64.0090 & -160.1704 & 55289 & KS \\
\hline & $5276^{\circ}$ & 64.0091 & $=160.7695$ & 55289 & $\times 5$ \\
\hline$\cdots$ & & 64.0091 & -160.1683 & 55290 & KS \\
\hline 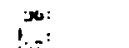 & 5219 & 64.0092 & -16 & & KS \\
\hline & 3219 & 04.0092 & -160.7601 & 55289 & KS \\
\hline & 3220 & 64.0092 & -160.1651 & 55280 & KS \\
\hline & 5221 & 64.0092 & -160.7638 & 55287 & KS \\
\hline & & 193 & $=160.7628$ & 55287 & ks \\
\hline & 5223 & 64.0093 & -160.7618 & $552 B 7$ & KS \\
\hline & 5 & & -160.1606 & 55288 & ks \\
\hline s. & 5225 & 64. & .7590 & 55288 & ks \\
\hline as: & 5226 & 64.0094 & -160.1585 & 55288 & ks \\
\hline & .5227 & 64.0095 & -160.7575 & 55283 & $\begin{array}{l}\mathrm{ks} \\
k \mathrm{c}\end{array}$ \\
\hline & 5228 & 64.0095 & -160.7563 & 55287 & ks \\
\hline & 5229 & 64.0095 & -160.1553 & 55288 & KS \\
\hline & 523 & 64.0095 & -160.7542 & 55287 & KS \\
\hline & 5231 & 64. & -160.7530 & 55281 & kS \\
\hline & & & .7520 & 55296 & KS \\
\hline & 52 & 4.00 & -160.7510 & 55285 & KS \\
\hline & 5234 & 64.0 & -160.7497 & 53285 & 23 \\
\hline & 5235 & 64.0097 & -160.7487 & $\begin{array}{l}3,212 \\
55,23\end{array}$ & $k s$ \\
\hline & 5236 & 64.0091 & -160.7471 & 55297 & ks \\
\hline & .5237 & 64.0098 & -160.7461 & 53231 & $\mathrm{k} ;$ \\
\hline
\end{tabular}

ATM. TOTAL STO THTAL STD STO CPS CPS COUNT ETH

29
23
19
32
32
21
27
29
32
29
31
20
24
20
21
28
29
27
27
18
33
33
32
24
20
29
29
35
36
33
25
23
23
20
30
29
33
31
26
35
38
25
24
24
35
27
41
30
34
32
30
40
26
30
CPS PPM $\begin{array}{ll}912 & 3.5 \\ 936 & 3.3\end{array}$ 4473.8 $1017 \quad 3.5$ 9563.3

$974 \quad 3.5$

$918 \quad 3.2$

918 3.2

$\begin{array}{ll}986 & 3.3 \\ 804 & 3.0\end{array}$

7893.0

7573.0

8092.7

8132.9

$172 \quad 2.5$

$\begin{array}{lll}164 & 2.7\end{array}$

8142.4

$789 \quad 2.4$

$770 \quad 2.1$

$\begin{array}{ll}695 & 1.9 \\ 633 & 1.7\end{array}$

6182.1

5952.1

6052.1

$523 \quad 1.9$

$\begin{array}{ll}645 & 1.9 \\ 547 & 2.1\end{array}$

5302.1

$502 \quad 1.9$

5512.2

593
669
6.1

$\begin{array}{ll}669 & 2.1 \\ 617 & 2.2\end{array}$

$\begin{array}{ll}617 & 2.2 \\ 684 & 2.5\end{array}$

$684 \quad 2.5$

6373.0

8523.0

8173.0

$908 \quad 3.0$

4913.5

9723.7

$\begin{array}{ll}1046 & 3.7 \\ 1050 & 3.3\end{array}$

$\begin{array}{ll}1050 & 3.3\end{array}$

$\begin{array}{ll}1016 & 3.5 \\ 1066 & 3.8\end{array}$

10654.0

$984 \quad 4.1$

11144.3

10824.1

10713.8

$\begin{array}{rr}946 & 4.0 \\ 1029 & 3.8\end{array}$
PEV CU 0
0 1.6 $\begin{array}{ll}0 & 1.6 \\ 0 & 1.5\end{array}$ 01.0 01.6 11.4 01.3 $0 \quad 1.3$ 01.3 $\begin{array}{ll}0 & 1.2 \\ 0 & 1.3\end{array}$ $-1 \quad 1.2$ $-1 \quad 1.3$ $-1 \quad 1.3$ $-11.4$ $-1 \quad 1.5$ $-1 \quad 1.4$ $-1 \quad 1.5$ $\begin{array}{ll}-1 & 1.4 \\ -1 & 1.5\end{array}$ $-1 \quad 1.4$

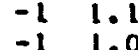
$-1 \quad 1.0$ $-10.8$ $-1 \quad 1.0$ $\begin{array}{ll}-1 & 1.0 \\ -1 & 0.9\end{array}$ $-1 \quad 1.0$ $\begin{array}{ll}-1 & 1.0 \\ -1 & 1.0\end{array}$ $-11.1$ $\begin{array}{ll}-1 & 1.1 \\ -1 & 1.0\end{array}$ $-11$. 01.0 01.0

01.3 o 1.2 01.3 $\begin{array}{ll}n & 1.2 \\ 0 & 1.4\end{array}$ $\begin{array}{ll}0 & 1.4 \\ 0 & 1.3\end{array}$ 01.3 $\begin{array}{ll}0 & 1.2\end{array}$ o 0.7 00.7 01.0 01. $\begin{array}{ll}0 & 1.2 \\ 0 & 1.4\end{array}$ $\begin{array}{ll}0 & 1.4 \\ & 1.7\end{array}$
STO

STO EU STO EU

EU

ETH

POT FLG DEV RATIO OEY. RATIO STD POTA STO

$\begin{array}{lllllll}0 & 0.6 & 0 & 0.5 & 1 & 2.8 & 0 \\ 0 & 0.6 & -.0 & 0.5 & 1 & 2.6 & 0\end{array}$

0.0 .6

00.6

00.6

$\begin{array}{ll}1 & 0.6 \\ 0 & 0.6 \\ 0 & 0.6\end{array}$

0 0.6

00.6

$\begin{array}{ll}0 & 0.6 \\ 0 & 0.5\end{array}$

00.5

00.5

$0 \begin{array}{lll}0 & 0.4 \\ 0 & 0.4 & 0.4\end{array}$

00.4

$\begin{array}{ll}0 & 0.4 \\ 0 & 0.4\end{array}$

00.4

$\begin{array}{ll}0 & 0.4 \\ 0 & 0.3\end{array}$

0.3

00.3

$\begin{array}{ll}-1 & 0.3\end{array}$

$\begin{array}{ll}-1 & 0.3 \\ -1 & 0.3\end{array}$

$-10.3$

$-10.3$

$\begin{array}{ll}-1 & 0.3 \\ -1 & 0.3\end{array}$

$\begin{array}{ll}-1 & 0.3 \\ -1 & 0.3\end{array}$

n 0.3

00.4

$\begin{array}{rr}-1 & 0.4 \\ 0 & 0.5\end{array}$

$\begin{array}{ll}-1 & 0.5\end{array}$

$\begin{array}{ll}-1 & 0.6 \\ 0 & 0.6\end{array}$

0.6

0.7

00.7

$\begin{array}{ll}0 & 0.7 \\ 0 & 0.7\end{array}$

$\begin{array}{ll}0 & 0.7 \\ 0 & 0.7\end{array}$

$0 \quad 0.8$

$0 \quad 0.8$

$\begin{array}{ll}0 & 0.8 \\ -1 & 0.8\end{array}$

$\begin{array}{ll}-1 & 0.8 \\ -1 & 0.8\end{array}$

$\begin{array}{rr}-1 & 0 . B \\ 0 & 0 . B\end{array}$

$0 \quad 0.8$

$\begin{array}{ll}0 & 0.7 \\ 0 & 0.7\end{array}$

AVERAGE RECORD MATA LINF 240 PAGE 3 $\begin{array}{ll}6.0 & 0 \\ 5.6 & 0 \\ 6.1 & 0 \\ 5.6 & 0 \\ 5.1 & 0 \\ 5.3 & 0 \\ 4.9 & 0 \\ 5.7 & 0 \\ 5.3 & 0 \\ 5.5 & 0 \\ 5.7 & 0 \\ 5.6 & 0 \\ 6.0 & 0 \\ 6.4 & 0 \\ 6.1 & 0 \\ 6.7 & 0 \\ 6.1 & 0 \\ 6.2 & 0 \\ 5.7 & 0 \\ 5.5 & 0 \\ 5.3 & 0 \\ 5.9 & 0 \\ 6.1 & 0 \\ 6.3 & 0 \\ 6.4 & 0 \\ 6.0 & 0 \\ 6.7 & 0 \\ 7.3 & 0 \\ 6.9 & 0 \\ 7.4 & 0 \\ 6.5 & 0 \\ 6.3 & 0 \\ 6.1 & 0 \\ 6.3 & 0 \\ 6.1 & 0 \\ 5.8 & 0 \\ 5.1 & 0 \\ 5.2 & 0 \\ 4.8 & 0 \\ 5.2 & 0 \\ 5.1 & 0 \\ 5.0 & 0 \\ 4.7 & 0 \\ 4.9 & 0 \\ 4.9 & 0 \\ 5.1 & 0 \\ 5.1 & 0 \\ 5.2 & 0 \\ 5.3 & 0 \\ 5.2 & 0 \\ 5.0 & 0 \\ 5.3 & 0 \\ 5.3 & 0 \\ & \end{array}$ 
A P P E N D I X H

DOE Single Record Reduced Data Tape 
DOE SINGIE RECORD REDUCED DATA TAPE

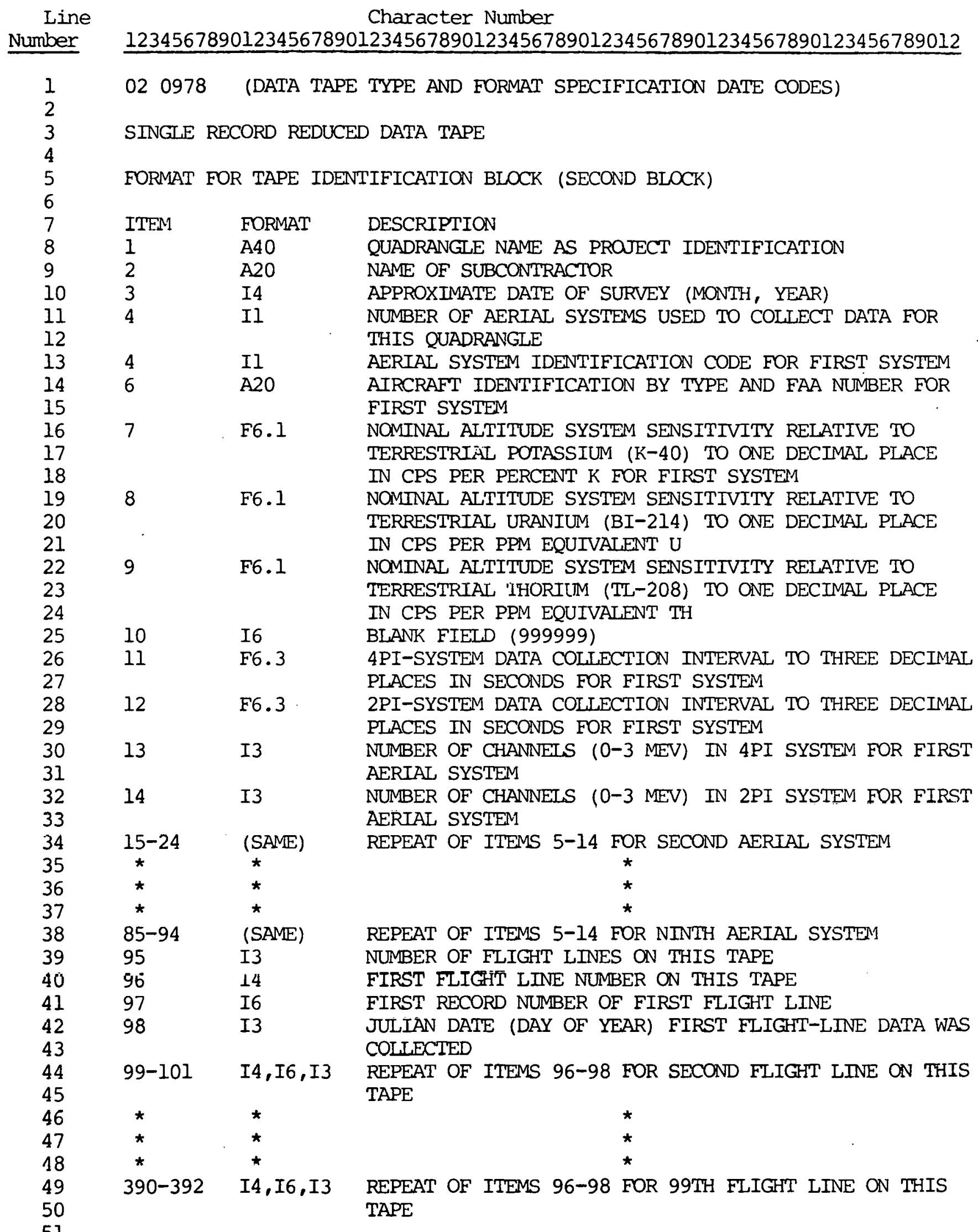


Line

Character Number

$\underline{123456789012345678901234567890123456789012345678901234567890123456789012}$

52 FORMAT FOR SINGLE RECORD REDUCED DATA RECORD (THIRD THRU LAST BLOCK)

53

54

ITEM

FORMAT

DESCRIPTION

55. 1 II

$\begin{array}{lll}56 & 2 & I 4\end{array}$

$57 \quad 3 \quad$ I6

$58 \quad 4 \quad I 6$

$59 \quad 5 \quad$ F8.4

60

61

62

63

64

65

66

67

68

69

70

71

72

F8. 4

F6.1

F7.1

$9 \quad A 8$

$10 \quad$ I4

$11 \quad$ F6.1

$12 \quad$ F4.1

AERIAL SYSTEM IDENTIFICATION CODE

FLIGHT LINE NUMBER

RECORD IDENTIFICATION NUMBER

GMT TIME OF DAY (HHMMSS)

LATITUDE TO FOUR DECIMAL PLACES IN DEGREES

LONGITUDE TO FOUR DECIMAL PLACES IN DEGREES

TERRAIN CLEARANCE TO ONE DECIMAL PLACE IN METERS

RESIDUAL (IGRF REMOVED) MAGNETIC FIEID INTENSITY

TO ONE DECIMAL PLACE IN GAMMAS

SURFACE GEOLOGIC MAP UNIT CODE

QUALITY FLAG CODES

APPARENT CONCENTRATION OF TERRESTRIAL POTASSIUM $(\mathrm{K}-40)$ TO ONE DECIMAL PLACE IN PERCENT K

UNCERTAINTY IN TERRESTRIAL POTASSIUM TO ONE DECIMAL PLACE IN PERCENT $K$

$13 \quad$ F6.1

APPARENT CONCENTRA'I'ION OF TERRESTRIAL URANIUMM

$14 \quad$ F4.I

(BI-214) TO ONE DECIMAL PLACE IN PPM EQUTVALENT U

UNCERTAINTY IN TERRESTRIAL URANIUM TO ONE DECIMAL

PLACE IN PPM EQUTVALENT U

$15 \quad$ F6.1

APPARENT CONCENTRATION OF TERRESTRIAL THORIUM

(TL-208) TO ONE DECIMAL PLACE IN PPM EQUIVALENT TH

$16 \quad$ F4.1

UNCEKI'ALNTY IN TERRESTRIAL THORIUM TO ONE DECIMAL

PLACE IN PPM EQUTVALENT TH

$17 \quad$ F6.1

URANIUIM-TO-THORIUM RATIO TO ONE DECIMAL PLACE IN

PPM EQUIVÄLENTT U PER PPM EQUTVALEN'I' 'IH

$18 \quad$ F6.1

URANIUM-TO-POTASSIUM RATIO TO ONE DECIMAL PLACE IN

PPM EQUIVALENT U PER PERCENT K

$19 \quad \mathrm{~F} 6.1$

THORIUM-TO-POTASSIUM RATIO TO ONE DECIMAL PLACE TN PPM EOUIVALENT TH PER PERCENT $K$

$20 \quad$ F8.1

GROSS GAMMA (0.4-3.0 MEV) COUNT RATE TO ONE DECIMAL PLACE IN COUNTS PER SECOND

$21 \quad$ F6.1

UNCERTAINTY IN GROSS GAMMA COUNT RATE TO ONE DECIMAL PLACE IN COUNTS PER SECOND

$22 \quad$ F5.1

ATMOSPHERIC BI-214 4PI CORRECTION TO ONE DECIMAL

PLACE IN PPM EQUIVALENT U

$23 \quad 54.1$

$24 \quad$ F4.1

UIVEERTAIINTY IIN AITUOSPHERIC BI-214 4PI CORRECTION

TO ONE DECIMAL PLACE IN PPM EQUTVALENT U

91

92

25

F5.1

OUTSIDE AIR TEMPERATURE TO ONE DECIMAL PLACE IN DEGREES CEISIUS

OUTSIDE AIR PRESSURE TO ONE DECIMAL PLACE IN MMHG 
APPEN D I X I

DOE Raw Spectral Data Tape 
DOE RAN SPECTRAL DATA TAPE

Line

Character Number

Number

$\underline{123456789012345678901234567890123456789012345678901234567890123456789012}$

1

2

010978 (DATA TAPE TYPE AND FORMAT SPECIFICATION DATE CODES)

RAW SPECTRAL DATA TAPE

FORMAT FOR TAPE IDENTIFICATION BLOCK (SECOND BLOCK ON TAPE)

ITEM

1

2

3

4

5

6

7

8

9

10

11

12

13

14

\section{5-17}

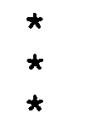

306-308
FORMAT

A40

A20

I4

Il

A20

I3

F6. 3

F6. 3

I3

I3

I3

I4

I6

I3

25

26

27

28

29

30

31

32

3.3

34

35

36

37

38

39

40

41

42

43

44

45

46

47

48

49

50

51

52

53

1 II

2 I4

$3 \quad I 6$

I6

F8. 4

F6. 1

F7.1

$9 \quad$ A8

$10 \quad \mathrm{~T} 4$

$11 \mathrm{~F} 4.1$

12 F5.

$13 \quad$ F5.3

14 I4

\section{DESCRIPTION}

QUADRANGLE NAME AS PROJFCT IDENTIFICATION

NANE OF SUBCONTRACTOR

APPROXIMATE DATE OF SURVEY (MONTH, YEAR)

AERIAL SYSTEM IDENTIFICATION CODE

AIRCRAFT IDENTIFICATION BY TYPE AND FAA NUMBER

BFEC CALIBRATION REPORT NUMBER

4PI SYSTEM DATA COLLECTION INTERVAL TO THREE DECIMAL PLACES IN SECONDS

2PI SYSTEM DATA COLLECTION INTERVAL TO THREE DECIMAL PLACES IN SECONDS

NUMBER OF CHANNELS (0-3 MEV) FOR 4PI SYSTEM

NUMBER OF CHANNEIS (0-3 MEV) FOR 2PI SYSTEM

NUMBER OF FLIGHT LINES ON THIS TAPE

FIRST FLIGHT LINE NUMBER ON THIS TAPE

FIRST RECORD NUMBER OF FIRST FLIGHT LINE

JULIAN DATA (DAY OF YEAR) FIRST FLIGHT LINE WAS COLLECTED

REPEAT OF ITEMS 12-14 FOR SECOND FLIGHT LINE ON THIS TAPE

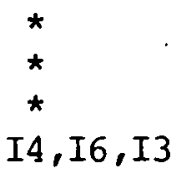

REPEAT OF ITEMS 12-14 FOR 99TH FLIGHT LINE ON THIS TAPE

FORMAT FOR RAW SPECTRAL DATA RECORD (THIRD THRU LAST BLOCK ON TAPE)

\section{ITEM FORMAT DESCRIPTION}

AERIAL SYSTEM IDENTIFICATION CODE

FLIGHT LINE NUMBER

RECORD IDENTIFICA'CION NUMBER

GNT TIME OF DAY (HHMMSS)

LATITUDE TO FOUR DECIMAL PLACES IN DEGREES

F8.4 LONGITUDE TO FOUR DECIMAL PLACES IN DEGREES

TERRAIN CLEARANCE TO ONE DECIMAL PLACE IN METERS

TOTAL MAGNETIC FIELD INTENSITY TO ONE DECIMAL PLACE IN GAMMAS

SURFACE GEOLOGIC MAP UNIT CODE

QUALITY FLAG CODES

OUTSIDE AIR TEMPERATURE TO ONE DECIMAL PLACE IN

DEGREES CEISIUS

OUTSIDE AIR PRESSURE TO ONE DECIMAL PLACE IN MMHG

LIVE TIME COUNTING PERIOD TO THREE DECIMAL PLACES IN SECONDS

SUMMED RAW OUTPUT FROM COSMIC CHANNELS (3-6 MEV) IN COUNTS 
Line Number

$54 \quad 15$

$55 \quad 16$

56

57

58

59
Character Number

123456789012345678901234567890123456789012345678901234567890123456789012

RAW OUTPUT FROM CHANNEL I IN COUNTS

RAW OUTPUT FROM CHANNEL 2 IN COUNTS

$\star$

$\star$

RAIN OUTPUT FROM CHANNEL 256 IN COUNTS 
A P P E N D I X K

DOE Statistical Analysis Data Tape 
DOE STATISTICAL ANALYSIS DATA TAPE

Line

Character Number

Number

123456789012345678901234567890123456789012345678901234567890123456789012

1

2

030978 (DATA TAPE TYFE AND FORMAT SPECIFICATION DATE CODES)

STATISTICAL ANALYSIS DATA TAPE

FORMAT FOR TAPE IDENTIFICATION BLOCK (SECOND BLOCK)

ITEM

FORMAT

1

2

3

4

11

12

13

14

15

21

$8 \quad$ F6.1

$9 \quad \mathrm{~F} 6.1$

10 I6

11 F6.3

$12 \quad$ F6.3

13 I3

$14 \quad$ I3

15-24 (SAME)

* $*$

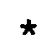

*

*

85-94 (SAME)

95 I3

$96 \quad$ I4

$97 \quad I 6$

98 I3
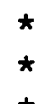

*

$*$

\section{DESCRIPTION}

QUADRANGLE NAME AS PROJECT IDENTIFICATION

NAME OF SUBCONTRACTOR

APPROXIMATE DATE OF SURVEY (MONTH, YEAR)

NUMBER OF AERIAL SYSTEMS USED TO COLIECT DATA FOR

THIS QUADRANGLE

AERIAL SYSTEM IDENTIFICATION CODE FOR FIRST SYSTEM AIRCRAFT IDENTIFICATION BY TYPE AND FAA NUMBER FOR FIRST SYSTEM

NOMINAL ALTITUDE SYSTEM SENSITIVITY RELATIVE TO TERRESTRIAL POTASSIUM $(\mathrm{K}-40)$ TO ONE DECIMAL PLACE IN CPS PER PERCENT $K$

99-101 I4,I6,I3

390-392 I4,I6,I3
NOMINAL ALTITUDE SYSTEM SENSITIVITY RELATIVE TO TERRESTRIAL URANIUM (Bl-214) TO ONE DECIMAL PLACE IN CPS PER PPM EQUTVALENT U

NOMINAL ALTITUDE SYSTEM SENSITIVITY RELATIVE TO TERRESTRIAL THORIUM (TL-208) TO ONE DECIMAL PLACE IN CPS PER PPM EQUIVALENT TH

BLANK FIELD (999999)

4PI-SYSTEM DATA COLLECTION INTERVAL TO THREE DECIMAL PLACES IN SECONDS FOR FIRST SYSTEM

2PI-SYSTEM DATA COLLECTION INTERVAL TO THREE DECIMAL PLACES IN SECONDS FOR FIRST SYSTEM

NUMBER OF CHANNELS (0-3 MEV) IN 4PI SYSTEM FOR FIRST AERIAL SYSTTM

NUMBER OF CHANNELS (0-3 MEV) IN 2PI SYSTEM FOR FIRST AERINL SYSTEM

REPEAT OF ITEMS 5-14 FOR. AERIAL SYSTEM

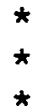

REPEAT OF ITEMS 5-14 FOR NINTH AERIAL SYSTEM

NUMBER OF FLIGHT LINES ON THIS TAPE

FIRST FLIGHT LINE NUMBER ON THIS TAPE

FIRST RECORD NUMBER OF FIRST FLIGHT LINE

JULIAN DATE (DAY OF YEAR) FIRST FLIGHT LINE DATA WAS COLLECTED

REPEAT OF ITEMS 96-98 FOR SECOND FLIGHT LINE ON THIS TAPE

REPEAT OF ITEMS 96-98 FOR 99TH FLIGHT LINE UN 'I'HLS TAPE 
Line Number

\section{2}

53

54

55

56

57

58

59
Character Number

12345678901234567890123456789013456789012345678901234567890123456789012

FORMAT FOR STATISTICAL ANALYSIS DATA RECORD (THIRD THRU LAST BLOCK)

$\begin{array}{lll}\text { ITEM } & \text { FORMAT } & \text { DESCRIPTION } \\ 1 & \text { I1 } & \text { AERIAL SYSTEM IDENTIFICATION CODE } \\ 2 & \text { I4 } & \text { FLIGHT LINE NUMBER } \\ 3 & \text { I6 } & \text { RECORD IDENTIFICATION NUMBER } \\ 4 & \text { I6 } & \text { GMT TIME OF DAY (HHMMSS) }\end{array}$

F8.4

F8. 4

F6.1

F7.1

A8

I5

11 F6.1

$12 \quad$ F4.I

$13 \quad$ F5.I

$14 \quad$ F6.1

$15 \quad$ F4.1

$16 \quad$ F5.1

17 FG.I

$18 \quad$ F4.I

$19 \quad$ F5.1

$20 \quad$ F8.1

$21 \quad F 6: I$

$22 \quad$ F5.1

$23 \quad$ F4.1

$24 \quad$ F6.1

$25 \quad$ F5.1

$26 \quad$ F6.1

$27 \quad$ F5.1

$28 \quad$ F6.1

$29 \quad$ F5.1
LATITUDE TO FOUR DECIMAL PLACES IN DEGREES

LONGITUDE TO FOUR DECIMAL PLACES IN DEGREES

TERRAIN CLEARANCE TO ONE DECIMAL PLACE IN METERS

RESIDUAL (IGRF REMOVED) MAGNETIC FIELD INTFNSTTY

TO ONE DECIMAL PLACE IN GAMMAS

SURFACE GEOLOGIC MAP UNIT CODE

OUALITY FLAG CODES

AVERAGED CONCENTRATION OF TERRESTRIAL POTASSIUM

(K-40) TO ONE DECIMAL PLACE IN PERCENT K

UNCERTAINTY IN TERRESTRIAL POTASSIUM TO ONE DECIMAL PLACE IN PERCENT K

POTASSIUM STANDARD DEVIATION FROM THE MEAN TO ONF: DECIMAL PLACE AND ALGEBRAICALLY SIGNED

AVERAGED CONCENTRATION OF TERRESTRIAL URANIUM

(BI-214) TO ONE DECIMAL PLACE IN PPM EQUTVALENT U

UNCERTAINTY IN TERRESTRIAL URANIUM TO ONE DECIMAL

PLACE IN PPM EQUIVALENT U

URANIUM STANDARD DEVIATION FROM THE MEAN TO ONE

DECIMAL PLACE AND ALGEBRAICALLY SIGNED

AVERAGED CONCEINTRA'I'IUN UH' 'IERRESTRIAL THORILMi

(TL-208) TO ONE DECIMAL PLACE IN PPM EQUIVALENT TH

UNCERTAINTY IN TFRRESTRIAL THORIUM TO ONF. DECIMAL

PLACE IN PPM EQUTVAT,FN'T' TH

THORIUM STANDARD DFVIATION FROM THF, MENN TH ONE

DECIMAL PLACE AND ALGEBRAICALLY SIGNED

GROSS GAMMA (0.4-3.0 MEV) COUNT RATE 'IO ONE DECIMAL PLACE IN COUNI'S PER SECOND

UNCERTATNTY IN GROSS GAIVIVA CUUN'I' RATE TO ONE DECIMAL PLACE IN COUNTS PER SECOND

ATMOSPHERIC BI-214 4PI CORRECTION TO ONE DECIMAL PLACE IN PRM EQUTVALITNT U

UNCERTAINTY IN ATMOSPHERIC BI-214 4PI CORRECTION TO ONE DECIMAL PLACE IN FFM EQUIVALENT U

AVERAGED URANIIIM-TD-THORIUM RATIO TO ONE DECIMAL PLACE IN PPM EQUTVALENT U PER PPM EQUTVALENT TH URANIUM-TO-THORIUM RATIO STANDARD DEVIATION FROM THE MFAN TO ONE DECIMAL PLACE AND ALGEBRAICALIY SIGNED AVERAGED URANIUM-TO-POTASSIUM RATIO TO ONE DECIMAL PLACE IN PPM EQUIVALENT U PER PERCENT K URANIUM-TO-POTASSIUM RATIO STANDARD DEVIATION FROM THE MEAN TO ONE DECIMAL PLACE AND ALGEBRAICALLY SIGNED

AVERAGED THORIUM-TO-POTASSIUM RATIO TO ONE DECIMAL PLACE IN PPM EQUIVALENT TH PER PERCENT K THORIUM-TO-POTASSIUM RATIO STANDARD DEVIATION FROM THE MEAN TO ONE DECIMAL, PLACE AND ALGEBRAICALLY SIGNED 


\section{A P PENDIX L \\ DOE Statistical Analysis Summary Data Tape}


DOE STATISTICAL ANALYSIS SUMMARY DATA TAPE

Line Number

1

2

Character Number

123456789012345678901234567890123456789012345678901234567890123456789012

050978 (DATA TAPE TYPE AND FORMAT SPECIFICATION DATE CODE)

STATISTICAL ANALYSIS SUMMARY TAPE (OR FILE)

FORMAT FOR TAPE IDENTIFICATION BLOCK (SECOND BLOCK)

$\begin{array}{ll}\text { ITEM } & \text { FORMAT } \\ 1 & \text { A40 } \\ 2 & \text { A20 } \\ 3 & \text { I4 } \\ 4 & \text { I6 }\end{array}$

DESCRIPTION

QUADRANGLE NAME AS PROJECT IDENTIFICATION NAME OF SUBCONTRACTOR

APPROXIMATE DATE OF SURVEY (MONTH, YEAR) NUMBER OF GEOLOGIC MAP UNITS USED FOR THIS QUADRANGLE

FORMAT FOR STATISTICAL ANALYSIS SUMMARY DAT RECORD (THIRD THRU LAST BLOCK)

\section{ITEM FORMAT DESCRIPTION}

$1 \quad$ A8

$2 \quad I 6$

$3 \quad$ I6

$4 \quad$ F6.1

$5 \quad \mathrm{~F} 6.1$

$6 \cdot \mathrm{A} 3$

$7 \quad \mathrm{I6}$

8 F6.1

$9 \quad F \in . I$

$10 \quad \mathrm{A3}$

11 I6

12 F6.I

13 F6.1

14 A3

$15 \quad \mathrm{I} 6$

$16 \quad$ F6.1

$17 \quad$ F6.1

$18 \quad A 3$

19 I6

$20 \quad$ F6.I

$21 \quad$ F6.I

$22 \quad A 3$ UNIT TH
SURFACE GEOLOGIC MAP UNIT IDENTIFYING CODE TOTAL RECORDS FOR GEOLOGIC MAP UNIT NUMBER OF POTASSIUM RECORDS COMPUTED FOR GEOLOGIC

POTASSIUM CONCENTRATION MEAN TO ONE DECIMAL PLACE IN PERCENT $\mathrm{K}$ POTASSIUM CONCEIVTRATION STANDARD DEVIAIIION TO ONE DECIMAL PLACE IN PERCENT K POTASSIUM CONCENTRATION DISTRIBUTION CODE NUMBER OF URANIUTY RECORDS COMPUTED FOR GEOLOGIC UNIT URANIUM CONCENTRATION MEAN TO ONE DECIMAL PLACE IN PPM EQUTVALENT U URANIUM CONCENTRATION STANDARD DEVIATION TO ONE DECIMAL PLACE IN PPM EQUTVALENT U URANIUM CONCENTRATION DISTRIBUTION CODE NIIMRFR OF THORIUM RECORDS COMPUTED FOR GEOLOGIC UNIT THORIUM CONCENTRATION MEAN TO ONE DECIMAL PLACE IN PPM EQUTVALENT TH THORIUM CONCENTRATION STANDARD DEVIATION TO ONE DECIMAL PLACE IN PPM EQUIVALENT TH THORIUM CONCENTRATION DISTRIBUTION CODE NUMBER OF URANIUM-TO-THORIUM RATIO RECORDS COMPUTED FOR GFOLOOGIC UNIT URANIUM-TO-THORIUM RATIO MEAN TO ONE DECIMAL PLACE' IN PPM EQUIVALENT U PER PPM EQUIVALENT TH URANIUM-TO-THORIUM RATIO STANDARD DEVIATION TO ONE DECIMAL PLACE IN PPM EQUIVALENNT U PER PPM EQUTVALENT

URANIUM-TO-THORIUM RATIO DISTRIBUTION CODE NUMBER OF URANIUM-TO-POTASSIUM RATIO RECORDS COMPUTED FOR GEOLOGIC UNIT URANIUM-TO-POTASSIUM RATIO MEAN TO ONE DECIMAL PLACE IN PPM EQUTVALENT U PER PERCENT $K$ URANIUM-TO-POTASSIUM RATIO STANDARD DEVIATION TO ONE DECIMAL PLACE IN PPM EQUIVALENT U PER PERCENT K URANIUM-TO-POTASSIUM RATIO DISTRIBUTION CODE 
Line Number

NUMBER OF THORIUM-TO-POTASSIUM RATIO RECORDS

$24 \quad$ F6.1 COMPUTED FOR GEOLOGIC UNIT

$25 \quad$ F6.1

$26 \quad A 3$

THORIUM-TO-POTASSIUM RATIO MEAN TO ONE DECIMAL PLACE IN PPM EQUTVALENT TH PER PERCENT K THORIUM-TO-POTASSIUM RATIO STANDARD DEVIATION TO ONE DECIMAL PLACE IN PPM EQUIVALENT TH PER PERCENT K THORIUM-TO-POTASSIUM RATIO DISTRIBUTION CODE 
A P P E N D I X M

DOE Magnetic Data Tape 
DOE MAGNETIC DATA TAPE FORMAT

Line

Character Number

Number

123456789012345678901234567890123456789012345678901234567890123456789012

040978 (DATA TAPE TYPE AND FORMAT SPECIFICATION DATE CODES)

MAGNETIC DATA TAPE

FORMAT FOR TAPE IDENTIFICATION BLOCK (SECOND BLOCK)

ITEM FORMAT DESCRIPTION

1 A40 QUADRANGLE NAME AS PROTECT IDENTIFICATION

2 A20 NAME OF SUBCONTRACTOR

3 I4 APPROXIMATE DATA OF SURVEY (MONTH, YEAR)

$4 \quad$ I3

$5 \quad \mathrm{I} 4$

$6 \quad$ I6

$7 \quad 13$

$8 \quad$ F8.4

$9 \quad$ F8. 4

10-14 (SAME)

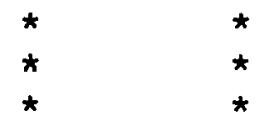

495-499 (SAME)

NUMBER OF FLIGHT LINES ON THIS TAPE

FIRST FLIGHT LINE ON THIS TAPE

FIRST RECORD NUMBER OF FIRST FLIGHT LINE

JULIAN DATA (DAY OF YEAR) FIRST FLIGHT LINE DATA WAS COLLECTED

LATITUDE OF GROUND BASE STATION TO FOUR DECIMAL

PLACES IN DEGREES FOR FIRST FLIGHT LINE

LONGITUDE OF GROUND BASE STATION TO FOUR DECIMAL

PLACES IN DEGREES FOR FIRST FLIGHT LINE

REPEAT OF ITEMS 5-9 FOR SECOND FLIGHT LINE ON THIS TAPE

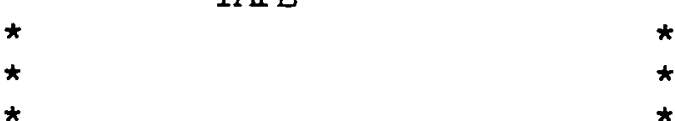

REPEAT OF ITEMS 5-9 FOR 99TH FLIGHT LINE ON THIS TAPE

FORMAT FOR MAGNETIC DATA RECORD (THIRD THRU LAST BIOCK)

$\begin{array}{ll}\text { ITEM } & \text { FORMAT } \\ 1 & \text { I1 } \\ 2 & \text { I4 } \\ 3 & \text { I6 } \\ 4 & \text { I6 } \\ 5 & \text { F8.4 } \\ 6 & \text { F8.4 } \\ 7 & \text { F6.1 } \\ 8 & \text { F5.1 } \\ 9 & \text { A8 } \\ 10 & \text { F7.1 } \\ 11 & \text { F7.1 } \\ 12 & \text { F7.1 } \\ 13 & \text { F7.1 }\end{array}$

DESCRIPTION

AERIAL SYSTEM IDENTIFICATION CODE

FLIGHT LINE NUMBER

RECRD IDFNTTFICATION NUMBER

GMT TIME OF DAY (HHMMSS)

LATITUDE TO FOUR DECIMAL PLACES IN DEGREES

LONGITUDE TO FOUR DECIMAL PLACES IN DEGREES

TERRAIN CLEARANCE TO ONE DECIMAL PLACE IN METERS OUTSIDE AIR PRESSURE TO ONE DECIMAL PLACE IN MMHG SURFACE GEOLOGIC MAP UNIT CODE

TMTAT. MAGNETIC FIELD INTENSITY TO ONE DECIMAL PLACE IN GAMMAS

RESTDIJAL (IGRF REMOVED) MAGNETIC FIELD INTENSITY TO ONE DECIMAL PLACE IN GAMMAS

DIURNAL MAGNETIC INTENSITY VARIATION TO ONE DECIMAL PLACE IN GAMMAS

MAGNETIC DEPTH-TO-BASEMENT TO ONE DECIMAL PLACE

IN METERS (IF REQUIRED) 
A P P E N D I X N

Reduced Calibration and Test Line Data 
$=\quad$ REDUCED CALIBRATION AND TEST LINE DATA

\begin{tabular}{cccccccccc} 
& & RES. THOR. & RES. THOR & \multicolumn{2}{c}{ LOW PRE } & \multicolumn{2}{c}{ LOW POST } \\
DATE & FLIGHT & .583 & 2615 & ALT. & T.C. & $2 \pi$ & ALT. & T.C. & $2 \pi$ \\
\hline $08 / 10 / 79$ & 27 & 9.7 & 5.7 & 320 & 2550 & 20 & 380 & 2600 & 17 \\
$08 / 15 / 79$ & 36 & 10.3 & 5.9 & 320 & 2700 & 25 & 380 & 2500 & 30 \\
$08 / 22 / 75$ & 43 & 10.4 & 6.2 & 400 & 1200 & 25 & 420 & 1350 & 23 \\
$08 / 22 / 79$ & 46 & 10.4 & 6.2 & 400 & 1200 & 25 & 420 & 1350 & 23 \\
$08 / 24 / 79$ & 52 & 10.0 & 5.8 & 360 & 2600 & 25 & 380 & 2550 & 20 \\
$08 / 31 / 79$ & 59 & 10.1 & 5.9 & 380 & 1350 & 22 & 420 & 1300 & 20 \\
$09 / 08 / 79$ & 62 & 9.9 & 5.6 & & & & 380 & 1350 & 27 \\
$09 / 08 / 79$ & 64 & 9.9 & 5.6 & & & & 380 & 1350 & 27
\end{tabular}

